University of Windsor Scholarship at UWindsor

$11-1-2015$

\title{
A review of structural patterns and melting processes in the Archean craton of West Greenland: Evidence for crustal growth at convergent plate margins as opposed to non- uniformitarian models
}

Ali Polat

Follow this and additional works at: https://scholar.uwindsor.ca/environmentalsciencepub

Part of the Tectonics and Structure Commons

\section{Recommended Citation}

Polat, Ali. (2015). A review of structural patterns and melting processes in the Archean craton of West Greenland: Evidence for crustal growth at convergent plate margins as opposed to non-uniformitarian models. Tectonophysics, 662, 67-94.

https://scholar.uwindsor.ca/environmentalsciencepub/4 
A review of structural patterns and melting processes in the

2 Archean craton of West Greenland: Evidence for crustal growth at

3 convergent plate margins as opposed to non-uniformitarian models

4

5

6

Ali Polat ${ }^{1,2 *}$, Lu Wang ${ }^{2,3}$, Peter W.U. Appel ${ }^{4}$

7

${ }^{1}$ Department of Earth and Environmental Sciences, University of Windsor, Windsor, ON,

8

Canada

${ }^{2}$ State Key Laboratory of Geological Processes and Mineral Resources and, China University of

Geosciences Wuhan, Wuhan 430074, China

$11{ }^{3}$ Center for Global Tectonics, China University of Geosciences Wuhan, Wuhan 430074, China

${ }^{4}$ Geological Survey of Denmark and Greenland, 1350-Copenhagen, Denmark

13

14

15

16

17

18

19

20

21

$22 *$ Corresponding author: polat@uwindsor.ca 
The Archean craton of West Greenland consists of many fault-bounded Eoarchean to

25 Neoarchean tectonic terranes (crustal blocks). These tectonic terranes are composed mainly of 26 tonalite-trondhjemite-granodiorite (TTG) gneisses, granitic gneisses, metavolcanic-dominated 27 supracrustal belts, layered anorthositic complexes, and late- to post-tectonic granites. Rock 28 assemblages and geochemical signatures in these terranes suggest that they represent fragments 29 of dismembered oceanic island arcs, consisting mainly of TTG plutons, tholeiitic to calc-alkaline 30 basalts, boninites, picrites, and cumulate layers of ultramafic rocks, gabbros, leucogabbros and 31 anorthosites, with minor sedimentary rocks. The structural characteristics of the terrane 32 boundaries are consistent with the assembly of these island arcs through modern style of 33 horizontal tectonics, suggesting that the Archean craton of West Greenland grew at convergent 34 plate margins. Several supracrustal belts that occur at or near the terrane boundaries are 35 interpreted as relict accretionary prisms. The terranes display fold and thrust structures and 36 contain numerous $10 \mathrm{~cm}$ to $20 \mathrm{~m}$ wide bifurcating, ductile shear zones that are characterized by a 37 variety of structures including transposed and redistributed isoclinal folds. Geometrically these 38 structures are similar to those occurring on regional scales, suggesting that the Archean craton of 39 West Greenland can be interpreted as a continental scale accretionary complex, such as the 40 Paleozoic Altaids. Melting of metavolcanic rocks during tectonic thickening in the arcs played an 41 important role in the generation of TTGs. Non-uniformitarian models proposed for the origin of 42 Archean terranes have no analogs in the geologic record and are inconsistent with structural, 43 lithological, petrological and geochemical data collected from Archean terranes over the last four 44 decades. The style of deformation and generation of felsic rocks on outcrop scales in the 
45 Archean craton of West Greenland and the Mesozoic Sulu orogenic belt of eastern China are

46 similar, consistent with the formation of Archean continental crust by subduction zone processes.

48 Keywords: West Greenland, Archean tectonics, Convergent margins, Shear zone, Accretionary complex, Sulu Orogen

\section{Introduction and scope}

Generation and destruction of Earth's continental and oceanic crusts in the Phanerozoic

53 Eon have been coupled with the Wilson cycle of plate tectonics (Oreskes, 2003). Phanerozoic

54 continental crust has been produced at convergent plate margins mainly through tectonic 55 accretion and emplacement of mantle-derived igneous rocks (Şengör et al., 1993, 2014; Burke, 56 2011). The main driving force behind present-day structural, magmatic, sedimentary and

57 metamorphic processes involved in the formation and evolution of the continental crust is plate tectonics, resulting from the flow of matter and energy between the lithosphere and

59 asthenospheric mantle along divergent, convergent, and transform plate boundaries (Şengör, 60 1990; Oreskes, 2013; Polat, 2014).

Nearly all geologists accept the idea that the Phanerozoic evolution of the Earth has been

62 shaped by plate tectonic processes. However, when it comes to the interpretation of the style of 63 tectonic processes and growth of the continental crust in the Precambrian, particularly in the 64 Archean Eon, the opinions of geologists diverge. Despite growing lines of field, geochemical, 65 geophysical and theoretical evidence indicating that the Earth has evolved through Phanerozoic-

66 like plate tectonic processes at least since $3.8 \mathrm{Ga}$ and that Archean continents originated mainly 67 at convergent plate margins (see Windley, 1993; Kusky and Polat, 1999; Polat et al., 2002; 
Furnes et al., 2007, 2013; Garde, 2007; Nutman et al., 2009, 2013, 2015a; Nebel-Jacobsen et al.,

69 2010; O’Neil et al., 2011; Adam et al., 2012; Amiguet et al., 2012; Kisters et al., 2012; Nagel et al., 2012; Arndt, 2013; Santosh et al., 2013; Wang et al., 2013; Turner et al., 2014; Kusky et al.,

71 2014), the nature of tectonic processes that generated Archean terranes continues to be debated

72 (e.g., Hamilton, 1988, 2013; Stern, 2005; Bédard, 2006; Robin and Bailey, 2009; Johnson et al.,

73 2014; Thébaud and Rey, 2013; Moore and Webb, 2013; François et al., 2014; Gerya, 2014; Dyck

74 et al., 2015; Kamber, 2015). In regards to the evolution of the Earth in the Archean, the

75 following questions are hotly debated: How far back in Earth history were geological processes

76 driven by plate tectonics? Were Archean crust-forming processes dominated by density-driven,

77 vertical crustal overturns, diapirs, drips, residue delaminations, and volcanic heat pipes without

78 any modern analogs? How did Archean greenstone belts form? Are Archean greenstone belts

79 and associated layered anorthosite complexes fragments of ophiolites? How did Archean

80 continents grow? Answers to all these questions remain elusive and controversial.

In this paper, we present new field data from Eoarchean to Neoarchean terranes in West

82 Greenland (Fig. 1), showing that the geometry and style of outcrop scale structures (e.g., fold 83 patterns) in shear zones are remarkably similar to those of regional-scale structures. We discuss

84 the importance of these similarities and their tectonic significance for the growth of Archean 85 continental crust. Then, we compare these Archean structures and the formation of Archean 86 felsic rocks (TTGs: tonalite, trondhjemite, granodiorite suites, granites) with those in the 87 Mesozoic Sulu orogen, eastern China, to address the above questions and revisit the tectonic 88 models proposed for the origin of Archean crust. Given the fact that all rocks in the Archean craton of West Greenland (also known as the North Atlantic craton) have been variably metamorphosed, the prefix 'meta' will be taken as implicit. 


\section{Archean geological record in West Greenland}

The Archean craton of West Greenland contains the world's best exposed rocks from the

93

94 interval ranging in age from 3850 to $2550 \mathrm{Ma}$, providing an excellent opportunity to study the early evolution of the Earth (Fig. 1). The craton has a very complex geologic history characterized by multiple phases of magmatic, structural and metamorphic events that took place between 3850 and 2550 Ma (see McGregor, 1973; Bridgwater et al., 1974, Kamber and Moorbath, 1998; Friend and Nutman, 1991; 2005a, 2005b, 2015a, 2015b; Nutman and Friend 2009; Windley and Garde, 2009). Presenting a detailed account of these geological events is beyond the scope and objective of this contribution.

The Archean craton in West Greenland consists mainly of Eoarchean to Neoarchean (ca. 3850-2700 Ma) orthogneisses with TTG compositions and 3660-2550 Ma granitic rocks (Nutman et al., 2004, 2013; Steenfelt et al., 2005, Windley and Garde, 2009; Hoffmann, 2014). The orthogneisses (ca. 65\%) and granites (ca. 15\%) constitute ca. 80\%, whereas the supracrustal rocks and layered anorthositic complexes form ca. 20\% of the craton (Fig. 1) (Kalsbeek and Myers, 1973; Wedepohl et al., 1991; Steenfelt et al., 2005). The TTG gneisses contain numerous meter- to kilometer-scale conformable layers of multiply-deformed supracrustal rocks (predominantly amphibolites) and layered anorthositic complexes consisting of an anorthosite, leucogabbro, gabbro and ultramafic rock association, with minor sedimentary rocks (Figs. 2, 3) (see Bridgwater et al., 1976; Myers, 1976, 1985; Garde, 1997, 2003; Windley and Garde, 2009; Nutman et al., 2007a; Windley, 1969). Contacts between the TTG gneisses and the supracrustal belts and anorthosite complexes are typically marked by 5 to 20 meter wide shear zones (Fig. 4). Trains of 1 to 200 meters wide, 1 to 1000 meters long concordant, parallel to the dominant foliation, lenses of amphibolite within the orthogneisses can be traced for several kilometers 
114 (Figs. 2, 3). These amphibolite lenses are likely to be relicts of earlier continuous layers that 115 were sheared, folded and redistributed by deformation. The thicknesses of supracrustal 116 associations and layered anorthositic complexes in some places reach up to 2 kilometers 117 (Windley and Garde, 2009). These rock types occur in alternating granulite and amphibolite 118 facies belts or zones (Bridgwater et al., 1976; Garde, 1990; Windley and Garde, 2009). 119 Greenschist facies supracrustal rocks are restricted to the Mesoarchean Tartoq Group (Windley 120 and Garde, 2009; Kisters et al., 2012; Szilas et al., 2013a).

The protoliths of the TTG gneisses were emplaced into the supracrustal rocks and spatially 122 associated anorthositic complexes (Wells, 1979, 1981, Nutman and Garde, 1989; Myers, 1985; 123 Windley and Garde, 2009; Polat et al., 2010; Hoffmann et al., 2012). The emplacement of the 124 TTGs took place mainly along thrust faults and was accompanied by recumbent isoclinal folding 125 (Myers, 1985; Hanmer et al., 2002; Hanmer and Greene, 2002; Garde, 1997, 2007; Windley and 126 Garde, 2009; Polat et al., 2010), resulting in significant crustal thickening. The TTG gneisses 127 also underwent extensive migmatization during a series of tectonothermal events (Friend and 128 Nutman, 2005a; Nutman et al., 2013; Hoffmann et al., 2011). The ca. 2550 Ma Qôrqut granites 129 were interpreted to have been derived from partial melting of Eoarchean and Mesoarchean 130 orthogneisses (Moorbath et al., 1981; Nutman and Friend, 2007). Recently, Næraa et al. (2014) 131 suggested that the Qôrqut granites were derived from Eoarchean mafic crust during late- to post132 accretion tectonic processes.

133 The petrogenetic origin of the TTGs has been attributed to diverse processes, including 134 melting of the sub-arc mantle wedge, subducted slabs and amphibolites in thickened arcs 135 (Nutman et al., 1996, 1999, 2004, 2013; Steenfelt et al., 2005; Garde, 2007; Tappe et al., 2011; 136 Kolb et al., 2012; Nagel et al., 2012; Szilas et al., 2012a; Hoffmann et al., 2011, 2014). Windley 
137 and Garde (2009) suggested that the TTGs were generated in mature island arcs and Andean138 type continental margins. Nutman et al. (2013) proposed that the protoliths of the Eoarchean 139 Itsaq Gneiss Complex were derived mainly from eclogitic mafic crustal rocks with subduction 140 geochemical characteristics.

141 Early generations of structures (e.g., $\mathrm{D}_{1}$ ) have been intensely overprinted and transposed by 142 the later structures (e.g., $\mathrm{D}_{2}-\mathrm{D}_{5}$; see Hall and Friend, 1979; Friend et al., 1988; Chadwick, 143 1990; Crowley, 2002; Kolb et al., 2012), resulting in complex fold and shear zone patterns. 144 Similarly, Eoarchean to Mesoarchean magmatic and metamorphic rocks were overprinted by the 145 Neoarchean tectonothermal events (e.g., Kalsbeek and Pidgeon, 1980; McGregor and Friend, 146 1992; Nutman et al., 1989, 1996; Nutman and Friend, 2007; Friend and Nutman, 2005a; Dziggel 147 et al., 2014; Keulen et al., 2014). Field and geochronological studies indicate that the Archean craton of West Greenland was 149 built by a series of collision events (Friend and Nutman, 1991, 2005a; Friend et al., 1988, 1996; 150 Nutman et al., 2004), and its formation can be best explained by horizontal tectonics that 151 involved accretion of island arcs and continental blocks (Bridgwater et al., 1976; Friend et al., 152 1988, 1996; McGregor et al., 1991; Nutman and Collerson, 1991; Crowley, 2002; Friend and 153 Nutman, 2001, 2005a; Windley and Garde, 2009). Bridgwater and co-workers (1974) were 154 among the first geologists to recognize the role of horizontal tectonics in the formation of poly155 phase fold and thrust structures, intrusion of multiple, syntectonic TTG plutons, and generation 156 of amphibolite to granulite facies metamorphic rocks. Later studies provided additional field 157 evidence for horizontal tectonics (Nutman and Collerson, 1991; Friend et al., 1988; Nutman et 158 al., 1989, 2002; Kisters et al., 2012; Nutman et al., 2013, 2015a, 2015b). Studies in the Isua 
159 region suggest that horizontal tectonic processes began as early as 3690 Ma (Hanmer et al.,

160 2002; Hanmer and Greene, 2002; Nutman and Friend, 2009; Nutman et al., 2009, 2015a).

161

162

163

164

165

166

167

168

169

170

171

172

173

174

175

176

177 Eoarchean Aasivik terrane, the Eoarchean Qarlit Tasersuat assemblage (terrane?), the

178 Mesoarchean to Neoarchean Akia terrane, the Eoarchean Isukasia terrane, the Mesoarchean

179 Kapisilik terrane, the Eoarchean Færinghavn terrane, and the Mesoarchean to Neoarchean Tre

180

181

\section{Tectonic models for the Archean craton of West Greenland}

Two major tectonic models have been proposed to explain the geologic history of the Archean craton of West Greenland: (1) terrane accretion model; and (2) arc crustal block accretion model. The main features of the models are summarized below.

\subsection{Terrane accretion model( $s)$}

On the basis of extensive field and zircon $\mathrm{U}-\mathrm{Pb}$ geochronological data, Friend and coworkers (Friend et al., 1987, 1988, 1996; Friend and Nutman, 2001, 2005; Nutman et al., 2007b) developed a terrane accretion, sensu lato, model to explain the geology of fault-bounded crustal domains, with distinct metamorphic, structural, and isotopic histories. The terrane model was first applied to the Godthåbsfjord (Nuuk) region by Friend et al. (1987). The model has been refined and extended to other regions of West Greenland, as new geochronological, field and geochemical data have been amassed over the last twenty-five years (Friend and Nutman 2005a;

Nutman and Friend, 2007, 2009; Garde, 2007; Polat et al., 2007, 2008, 2009b; Nutman et al., 2004, 2009). The revised model includes, from north to south, the following terranes: the

Brødre, Tasiusarsuaq, Sioraq, Paamiut, Neria, and Sermiligaarsuk terranes (Fig. 1; see Rosing et al., 2001; Nutman et al., 2004; Friend and Nutman, 2001, 2005a; Nutman and Friend, 2007, and 
182 references therein). The Eoarchean Aasivik and Qarlit Tasersuat terranes occur within

183 Mesoarchean to Neoarchean rocks. The Neria terrane is interpreted as a refolded nappe (see

184 Windley and Garde, 2009). All terranes are composed mainly of juvenile rocks and were

185 assembled through several collision events in the late Archean (Nutman et al., 2004, 2007b;

186 Friend and Nutman, 2005a, 2005b; Steenfelt et al., 2005; Polat et al., 2008, 2010; Hoffmann et

187 al., 2012: Szilas et al., 2013a). These terranes underwent poly-phase, high-strain heterogeneous 188 deformation and multiple episodes of metamorphism resulting from several tectonothermal 189 events (Friend and Nutman, 2001). Although these tectonic terranes have distinct sequences of 190 structural, metamorphic, and magmatic events (Friend and Nutman, 2005a), they have broadly 191 similar rock types, and styles of deformation, magmatism and metamorphism (Windley and 192 Garde, 2009). However, the order and subduction polarity of collisions between different 193 terranes have not been well established.

194 Some terranes, such as the Eoarchean Isukasia terrane, are composite terranes, including 195 several tectonically juxtaposed lithotectonic fragments (Nutman et al., 2015a). The Akia terrane 196 also contains two, 3220 Ma and 3071-2990 Ma, crustal blocks (Garde, 1997, 2007).

197 The terrane boundaries are marked by up to 200 meter wide mylonitized, amphibolite 198 facies volcanic and sedimentary rocks and serpentinites. Nutman and Friend (2007) proposed 199 that these mylonitized rocks are deeper crustal equivalents of parautochthonous cover sequences 200 and allochthonous ophiolitic/accretionary assemblage nappes occurring in Phanerozoic orogens. 201 The mylonitized accretionary prisms between various tectonic blocks are interpreted to mark the 202 closure of Archean ocean basins by horizontal tectonics. In the context of plate tectonics, the 203 terranes and terrane boundaries can be defined as "tectonic blocks" and "suture zones", 204 respectively. Field observations indicate that most rocks in these terranes underwent an early 
205 phase of isoclinal folding, followed by a second generation of isoclinal recumbent nappe 206 formation (Berthelsen and Henriksen, 1975, Friend et al., 1988, 1996; Windley and Garde, 207 2009). Thrust faults between different terranes were folded during the late Archean accretion 208 events at 2710-2720 Ma and 2650-2600 Ma (Friend et al., 1988; Nutman and Friend, 2007).

209 Terrane accretion was followed by regional recumbent isoclinal folding and superimposed 210 upright folding (Nutman and Friend, 2007). Collisions between the terranes were also 211 accompanied by magmatism and metamorphism (Fiend et al., 1988; Windley and Garde, 2009; 212 Dziggel et al., 2014). Folding, shearing and metamorphic recrystallization obliterated most, if not 213 all, kinematic indicators in the mylonitized terrane boundaries (Friend and Nutman, 2001), 214 making it difficult to determine subduction polarity.

\subsection{Arc crustal accretion model}

The arc crustal accretion model for the Archean craton of West Greenland has been 218 proposed by Windley and Garde (2009). In this model the craton is divided into six fault219 bounded tectonic blocks that display similar geological cross sections. These blocks, from north 220 to south, consists of the Maniitsoq, Fiskefjord, Sermilik, Bjørnesund, Kvanefjord, and Ivittuut 221 blocks. In this model each block consists of southerly upper and northerly lower zones. The 222 upper zones are characterized by prograde amphibolite facies metamorphism, whereas the lower 223 zones display granulite facies metamorphism; some parts of these zones are partly to completely 224 retrogressed to amphibolite facies. According to Windley and Garde (2009), the tectonic blocks

225 are remnants of Archean island arcs and Andean-type continental margins. The Godthåbsfjord 226 region, where the Færinghavn, Tre Brødre, Kapisilik and Isukasia terranes of Friend and Nutman 
227 (2005a) are located, is defined as the Godthåbsfjord-Ameralik belt. The boundaries between 228 some crustal blocks overlap with the terrane boundaries.

It is suggested that the style of deformation changes downward within crustal blocks in that upper zones were mostly deformed by one major phase of isoclinal folding, and lower zones underwent two to three phases of kilometer-scale folding, resulting in complex fold interference

232 patterns. In all blocks TTG protoliths have extensively intruded supracrustal rocks and associated 233 layered anorthositic complexes mainly along shear zones. Because of intense deformation and 234 extensive TTG intrusion, the supracrustal rocks and anorthosite, gabbro, leucogabbro and 235 ultramafic rock layers are preserved mainly as trains of lenses or folded lenses (Windley and 236 Garde, 2009). These blocks were thickened by a combination of thrusting, isoclinal folding and 237 TTG intrusion. Given that the terrane terminology has been embedded in the literature for over 238 twenty-five years, we will continue to use this terminology. tectonic assemblages, the tectonic processes and crust-building events proposed by the two models to explain the evolution of the Archean craton in West Greenland are broadly similar, 242 involving lateral accretion of juvenile igneous rocks. Both models suggest that Archean crustal 243 growth in West Greenland is a product of prolonged, complex tectonothermal events and 244 comparable to those of Phanerozoic orogenic belts.

\section{Supracrustal belts, layered anorthositic and ultramafic rocks}

Supracrustal belts (or greenstone belts) are the lithotectonic assemblages of metamorphosed volcanic and sedimentary rocks, containing variable proportions of ultramafic to mafic intrusive rocks. The majority of supracrustal belts in the Archean craton of West 
250 Greenland underwent amphibolite or granulite facies metamorphism (Windley and Garde, 2009).

251 The Mesoarchean (3000 Ma) Tartoq supracrustal belt is the only one that preserves greenschist

252 facies metamorphism (Kisters et al., 2012; Szilas et al., 2013a, and references therein).

253 The Mesoarchean supracrustal rocks in West Greenland are often temporally and spatially

254 associated with an assemblage of layered anorthositic complexes (Windley and Smith, 1974,

255 1976; Myers, 1985; Dymek and Owens, 2001; Polat et al., 2008; 2009a, 2011a, 2011b;

256 Hoffmann et al., 2012). Despite multiple phases of deformation and amphibolite to granulite

257 facies metamorphism, pillow structures, cumulate textures and igneous layering are locally well

258 preserved in many supracrustal belts and anorthositic complexes.

259 In the following sections, we review the major geological characteristics of these belts and

260 layered complexes. Emphasis are placed on the Isua, Ivisaartoq-Ujarassuit, Storø, Fiskenæsset,

261 Bjørnesund, Ravns Storø and Tartoq supracrustal belts, and the Fiskenæsset anorthosite complex

262 (Fig. 1) that have been studied by the senior author (see Polat et al., 2011a, 2012). In addition,

263 we summarize the main geological features of the Qussuk-Bjørneøen and Grædefjord

264 supracrustal belts, layered ultramafic rocks in the Isukasia terrane, and the Naajat Kuuat 265 anorthosite complex (Fig. 1).

266

267 4.1. Supracrustal belts

268 4.1.1. The Eoarchean Isua supracrustal belt

269 The Isua supracrustal belt is the largest Eoarchean volcanic and sedimentary rock 270 assemblage in West Greenland (Keto and Kurki, 1967; Allaart, 1976; Bridgwater et al., 1976;

271 Nutman, 1986; Nutman et al., 1997, 2009, 2013; Appel et al., 1998; Myers, 2001; Nutman and

272 Friend, 2009). It is exposed within the Itsaq Gneiss Complex in the composite Isukasia terrane 
273 (Nutman et al., 1997, 2009, 2013). Geochronological and isotopic studies indicate that the belt 274 contains rocks ranging in age from 3800 to 3700 Ma (Moorbath et al., 1973; Baadsgaard et al., 275 1986; Kamber et al., 1998; Nutman et al., 1997, 2002, 2009; Frei et al., 2004; Nutman and 276 Friend, 2009; Hoffmann et al., 2010). On the basis of field relationships and geochronological 277 data, Nutman and co-workers (Nutman and Friend, 2009; Nutman et al., 2009; Nutman et al., 278 2015a) showed that the belt and bordering orthogneisses belong to two tectonically-juxtaposed 279 sub-terranes: a ca. 3800 Ma southern sub-terrane and a ca. 3700 Ma northern sub-terrane. These 280 sub-terranes appear to have been juxtaposed between 3680 and $3660 \mathrm{Ma}$. The boundary between 281 these two sub-terranes is characterized by strongly mylonitized sedimentary rocks consisting of 282 carbonate, chert, and banded iron formation (BIF). Both the northern and southern sub-terranes 283 are composed of similar lithologies including mafic to ultramafic volcanic rocks, ultramafic 284 layers, chert, and BIF (Nutman et al., 2009; Appel et al., 1998; Myers, 2001; Friend et al., 2008; 285 Nutman and Friend, 2009; Nutman et al., 2009, 2015a). The Isua supracrustal belt has undergone several phases of deformation and amphibolite 287 facies metamorphism (Nutman et al., 1984; Myers, 2001; Nutman et al., 2002, 2007b; Hanmer et 288 al., 2002; Nutman and Friend, 2009). Although the belt underwent poly-phase deformation and 289 amphibolite facies metamorphism, low-strain zones contain primary volcanic and sedimentary 290 structures, including pillow structures, pillow breccia and conglomerates (Fig. 5) (Appel et al., 291 1998, 2009, Komiya et al., 1999; Fedo, 2000; Myers, 2001; Polat et al., 2002; Friend et al., 2008; 292 Furnes et al., 2007; de Wit et al., 2013). The style of deformation (e.g., thrust faults, asymmetric 293 and overturned folds) and the nature of lithologies (e.g., pillow basalts, cherts, serpentinized 294 peridotites) in the Isua belt are similar to those in Phanerozoic suture zones (Figs. 5, 6). 
The ca. 3800 Ma sub-terrane contains a suite of picrites to basalts with a transitional to tholeiitic affinity, and "enriched" basalts with a calc-alkaline affinity (Polat and Hofmann, 2003; Jenner et al., 2009). The ca. 3700 Ma sub-terrane consists of an association of picrites to basalts with a calc-alkaline to transitional affinity; and a suite of boninites with a tholeiitic affinity (Polat et al., 2002, 2011a, Polat and Hofmann, 2003; Appel et al., 2009; Hoffmann et al., 2010). The trace element systematics of volcanic rocks in both sub-terranes are consistent with subduction zone geochemical signatures, suggesting that they originated in a forearc or possibly in a juvenile oceanic island arc tectonic setting (Polat and Hofmann, 2003; Jenner et al., 2009; Furnes et al., 2007, 2009; Hoffmann et al., 2010).

On the basis of field relationships, geochemistry and geochronology, Nutman et al. (2015a) showed that the rocks in the northern sub-terrane are characterized by tectonic imbrication and display a temporal shift from mafic, through intermediate, to felsic composition, consistent with the formation of the sub-terrane in an intra-oceanic island arc, called "proto-arc". They also attributed the intrusion of the imbricated supracrustal rocks by the 3700-3690 Ma calc-alkaline tonalities to the maturation of the "proto-arc", resulting from partial melting of eclogitized mafic crust at the base of the tectonically thickened arc (cf., Hoffmann et al., 2011). In contrast, Polat and Frei (2005) argued that ridge subduction played an important role in the partial melting of the imbricated arc crust to produce TTGs.

\subsubsection{The Mesoarchean (ca. 3075 Ma) Ivisaartoq-Ujarassuit supracrustal belt}

The Mesoarchean (ca. $3075 \mathrm{Ma}$ ) volcanic and sedimentary rocks exposed in the Ivisaartoq and Ujarassuit areas in the upper Godthåbsfjord (Nuuk) region are part of the same lithotectonic assemblage (Fig. 1) (Hall and Friend, 1979; Chadwick, 1990; Friend and Nutman, 2005a; Polat 
et al., 2007, 2008; Ordóñez-Calderón et al., 2009; Nutman et al., 2015b).

The Ivisaartoq-Ujarassuit belt is the largest Mesoarchean supracrustal lithotectonic assemblage in the Godthåbsfjord region (Fig. 1). The belt occurs within the Mesoarchean (3075$2950 \mathrm{Ma}$ ) Kapisilik terrane (Friend and Nutman, 2005a), which is tectonically bounded by the Eoarchean (3870-3600 Ma) Isukasia terrane to the north, and by the Eoarchean Færingehavn and the Neoarchean Tre Brødre terranes to the south and west, respectively (see Friend and Nutman, 2005a; Polat et al., 2007). Nutman et al. (2015b) have recognized a Mesoarchean tectonic klippe of dismembered mafic to ultramafic rocks, formerly belonging to the Ivisaartoq-Ujarassuit supracrustal belt, in the southern part of the Isuakasia terrane, suggesting that the Kapisilik terrane was tectonically emplaced over the Isukasia terrane at about 2970 Ma.

The primary igneous structures, including pillow basalts, pillow breccia and magmatic layering, are better preserved in the Ivisaartoq area than the Ujarassuit counterpart (Chadwick, 1990; Polat et al., 2007, 2008; Ordóñez-Calderón et al., 2009).

The Ivisaartoq section of the supracrustal belt is composed predominantly of pillow basalts, picrites, gabbros and serpentinized peridotites, with minor diorites and siliceous, pyritebearing volcaniclastic rocks (Fig. 7) (Hall and Friend, 1979; Hall, 1980; Chadwick, 1985, 1990; Polat et al., 2007, 2008, 2009a). The pillow basalts are characterized by a tholeiitic affinity and display well-preserved core and rim structures (Hall, 1980; Chadwick, 1990; Polat et al., 2007, 2008, 2009a). Calc-silicate metasomatic alteration, consisting mainly of an assemblage of epidote, quartz, hornblende, diopside, calcite and garnet, is widespread in the pillow basalts, gabbros and diorites (Fig. 7a, b) (Polat et al, 2007; Ordóñez-Calderón et al., 2009). Peridotites are exposed discontinuously as three major layers throughout the sequence (Fig. 7d) (Chadwick, 1985, 1990). In several locations the gabbros contain up to 15 centimetres long anorthosite 
341 xenoliths (Polat et al., 2008). Sedimentary rocks are composed of quartzitic gneisses, biotite 342 schists, and cherts (Chadwick, 1985, 1990; Ordóñez-Calderón et al., 2009). The siliceous 343 volcaniclastic rocks yielded a zircon U-Pb age of 3075 15 Ma (Friend and Nutman, 2005a; Polat 344 et al., 2007).

Migmatites occur at the contact between the Isukasia and Kapisilik terrane (Fig. 7e), 346 suggesting that amphibolites were partially melted during tectonic juxtaposition of these terranes 347 at about $2970 \mathrm{Ma}$. The tectonic collision between the two terranes produced asymmetric folds 348 and refolded thrust structures in the Ujarassuit area (Fig. 7f). The Ujarassuit part of the belt is 349 dominated by basaltic amphibolites, with rare pillow structures (Ordóñez-Calderón et al., 2009). 350 In addition, basaltic andesites, andesites, boninites, peridotites, and volcaniclastic rocks are 351 exposed in the Ujarassuit area (Ordóñez-Calderón et al., 2009).

352 The presence of abundant pillow basalts, evidence for extensive high-temperature seafloor 353 hydrothermal alteration (epidosites), and subduction zone geochemical characteristics of the 354 basalts, boninites, picrites, andesites, basaltic andesites, gabbros, anorthosites, and diorites in the 355 Ivisaartoq-Ujarassuit supracrustal are collectively consistent with the formation of the belt as a 356 Mesoarchean subduction-related ophiolite (see Polat et al., 2007, 2008; Ordóñez-Calderón et al., 357 2009; Dilek and Polat, 2008; Furnes et al., 2015).

\subsubsection{The Mesoarchean (ca. 3080 Ma) Qussuk-Bjфrneфen supracrustal belt}

The Mesoarchean Qussuk-Bjørneøen supracrustal belt (Fig. 1) is located at the eastern 361 edge of the Akia terrane, or the Fiskefjord crustal block of Windley and Garde (2009), in the

362 Godthåbsfjord region (Garde 1997, 2007; Garde et al., 2012). The belt includes numerous slices 363 of intensely deformed volcanic, volcaniclastic, and intrusive rocks, including tholeiitic basalts, 
andesites, gabbros, and orthopyroxene-rich ultramafic cumulates (Garde, 2007). Relict pillow structures are preserved at Bjørneøen. Volcaniclastic rocks in the central Bjørneøen and near the head of Qussuk have a zircon U-Pb age of 3071 Ma (Garde et al., 2007, 2012). The belt was intruded by voluminous TTGs at ca. $3000 \mathrm{Ma}$. Although main contacts between the supracrustal rocks and the TTG gneiss are tectonic or tectonized, intrusive relationships are well documented in many outcrops (Garde, 2007). The supracrustal rocks and the TTG gneisses were intruded by syntectonic granites at 3005-2980 Ma and metamorphosed at amphibolite facies conditions between 2990 and 2970 Ma. The Qussuk-Bjørneøen belt shares the lithological and geochronological features of the ca. 3075 Ma Ivisaartoq-Ujarassuit belt (see Polat et al., 2008; Ordóñez-Calderón et al., 2009). The geochemical characteristics of the Qussuk-Bjørneøen supracrustal rocks are consistent with an oceanic island arc setting (Garde, 2007).

\subsubsection{The Mesoarchean to Neoarchean Storø supracrustal belt}

The Storø supracrustal belt (Fig. 1) is in a structural contact between two terranes; the Eoarchean Færingehavn terrane to the east, and the Mesoarchean Akia terrane to the west (Friend and Nutman, 2005a; Hollis, 2005, Nutman et al., 2007b; Nutman and Friend, 2007; van Gool et al., 2007). The belt is characterized by tectonically imbricated Mesoarchean (3060 Ma) and Neoarchean (ca. $2800 \mathrm{Ma}$ ) amphibolite facies igneous and sedimentary rocks, consisting of basalts (amphibolites), anorthosite-leucogabbro-gabbro association, garnet-biotite gneisses, quartzitic gneisses, and ultramafic rocks (Fig. 8) (Hollis et al., 2004; Knudsen et al., 2007; Østergaard and van Gool, 2007; van Gool et al., 2007; Ordóñez-Calderón et al., 2011; Scherstén et al., 2012; Szilas and Garde, 2013; Szilas et al., 2014). Sedimentary rocks locally underwent migmatization (Fig. 8e). Contacts between the Mesoarchean and Neoarchean supracrustal rocks 
387 and the neighboring Eoarchean to Neoarchean TTG gneisses are typically marked by mylonites.

388 Based on their field characteristics and locations in the tectonostratigraphy, amphibolites are

389 divided into lower (homogeneous) and upper (banded) units (van Gool et al., 2007; Ordóñez-

390 Calderón et al., 2011). The lower amphibolites are intruded by the anorthosite-leucogabbro-

391 gabbro association that is in turn intruded by a ca. 3050 Ma tonalite sheet. Polyphase

392 deformation (Fig. 8b) and amphibolite facies metamorphism during terrane accretion between ca.

3932650 and 2600 Ma have obliterated most of primary textural and mineralogical characteristics of

394 the igneous and sedimentary rocks. The geochemical characteristics of the Storø amphibolites

395 are consistent with a subduction zone geodynamic setting and partial melting of a shallow $(<80$

$396 \mathrm{~km}$ ) mantle source (Ordóñez-Calderón et al., 2011).

397

398

4.1.5. The Mesoarchean Gradefjord supracrustal belt

399 The Grædefjord supracrustal belt (Fig. 1) is located to the south of Grædefjord in the 400 Tasiusarsuaq terrane, at the contact between the Bjørnesund and Sermilik blocks in Windley and

401 Garde (2009). The belt is dominated by strongly deformed mafic, ultramafic, and andesitic 402 amphibolites, and intruded by the 2950-2880 Ma TTGs (Kalsbeek and Pidgeon, 1980; Pidgeon 403 and Kalsbeek, 1978; Szilas et al., 2013b). Both the supracrustal rocks and TTGs were 404 metamorphosed under amphibolite to lower granulite facies conditions (Pidgeon and Kalsbeek, 405 1978; McGregor and Friend, 1992; Nutman and Friend, 2007; Riciputi et al., 1990; Schumacher 406 et al., 2011). Szilas et al. (2013b) interpreted the Grædefjord supracrustal rocks having formed in 407 a subduction zone setting. Our unpublished geochemical data from this belt support this 408 interpretation. 


\subsubsection{Mesoarchean supracrustal rocks in the Fiskenasset region}

Supracrustal rocks associated with the Fiskenæsset anorthosite complex are characterized by both layered and massive amphibolites (Myers, 1985; Weaver et al., 1981, 1982; Polat et al., 2009b). Mineralogically, the amphibolites are composed of hornblende and plagioclase, with minor pyroxene, epidote, quartz, and garnet (Fig. 9a-c) (Polat et al., 2009b). The protoliths of the TTG gneisses were emplaced as sub-concordant layers between the stratigraphic units of the Fiskenæsset anorthosite complex and the associated amphibolites mainly along thrust faults. On a meter to kilometer scale, the TTG gneisses separate the amphibolites and the units of the anorthosite complex into thin layers and trains of lenses. Despite intense deformation, intrusive relationships between the TTG gneisses and amphibolites are locally preserved in the Majorqap qâva and Sinarssuk areas. Because of several phases of ductile deformation and extensive shearing, pillow structures in the Fiskenæsset amphibolites are preserved only in several outcrops (Escher and Myers, 1975; Polat et al., 2009b). The anorthosite complex, supracrustal rocks and TTG gneisses were affected by granulite facies metamorphism and retrogressed under upper-amphibolite facies conditions (Myers, 1985; McGregor and Friend, 1992; Schumacher et al., 2011).

The majority of amphibolite layers in the Fiskenæsset region have subduction zone geochemical signatures. Four amphibolite samples from Bjørnesund and Nunatak have a highmagnesian andesitic composition, providing additional evidence for subduction zone geodynamic processes (Polat et al., 2009b). Samples from several locations display N-MORBlike trace element patterns (Weaver et al., 1981, 1982; Polat et al., 2009b). The Fiskenæsset anorthosite complex and the associated amphibolites are inferred as relicts of Mesoarchean supra-subduction zone oceanic crust (Polat et al., 2009b, 2010, 2011a, 2011b, 2012). 


\subsubsection{The Mesoarchean Bjфrnesund and Ravns Storф supracrustal belts}

The Bjørnesund and Ravns Storø (also known as Ikkattup Nunaa) supracrustal belts (Fig. 1) are located to the south of the Fiskenæsset Complex in the Tasiusarsuaq terrane (Andersen and Friend, 1973; Andersen, 1974; Windley and Garde, 2009; Szilas et al., 2012a; Keulen et al., 2014). These belts are composed of similar rock types and were affected by similar deformation, magmatic and metamorphic events, suggesting that they were part of an originally continuous Mesoarchean supracrustal belt (Windley, 1968; Friend, 1975; Anderson, 1974; Windley and Garde, 2009; Szilas et al., 2012a; Keulen et al., 2014). The belts underwent mid to upper amphibolite facies metamorphism, three phases of folding, thrusting and strike-slip deformation (Fiend, 1975; Keulen et al., 2014). The Ravns Storø belt contains ca. 2908 Ma biotite \pm garnet quartzo-feldspathic gneisses of a probable sedimentary or a volcaniclastic origin (Andersen and Friend, 1973; Nutman et al., 2004).

Supracrustal rocks in the southern part of the Ravns Storø belt are intruded by the $2878 \pm 10$ Ma tonalities (Friend and Nutman, 2001). Keulen et al. (2014) showed that the Bjørnesund and Ravns Storø are intruded by the 2970 Ma Fiskenæsset anorthosite complex, 2920 Ma diorite and 2910-2880 Ma granodiorite. Szilas et al. (2012a) reported a ca. $2900 \mathrm{Ma}$ zircon U-Pb age for fine-grained TTG sheets that intrude both belts. Amphibolites from these belts yielded $3020 \pm 78$

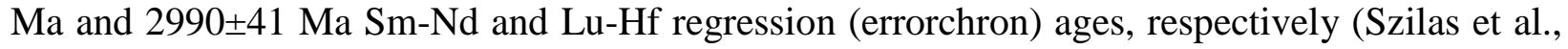
2012a). These ages suggest that the Bjørnesund and Ravns Storø belts formed at ca. 3000 Ma.

On the island of Ikkattup Nunaa, amphibolites, ultramafic schists (serpentinites, actinolite schists), mafic to felsic tuffs, pyroclastic rocks (e.g., lapilli tuffs, and ignimbrites), garnet-mica schists, deformed pillow basalts, and gabbros are the major rock types (Fig. 9d-e). In addition to these rocks, there are garnet amphibolites, quartz-feldspar-mica schists, and mafic to felsic dykes 
456 in the belt. Contacts between different rock types, except for dikes, are predominantly structural,

457 including asymmetric folds, S-C planar fabrics, and quartz veins. Outcrops of deformed pillow

458 structures were observed only in a few localities (Fig. 9e). These pillows are strongly deformed

459 and contain epidote-rich calc-silicate metasomatic mineral assemblages. Carbonate and silica

460 alteration occur mainly along foliation planes in the amphibolites.

461 Rock types at Bjørnesund are similar to those on Ikkattup Nunaa, consisting predominantly

462 of gabbros, amphibolites, deformed pillow basalts, and serpentinites (Fig. 9f). Similarly, contacts

463 between different lithologies are marked by deformation, quartz veins, and carbonate and silica

464 alteration. Contacts between gneisses and greenstone belts are generally characterized by strong

465 deformation (folding and shearing), but intrusive relationships have also been observed.

466 The trace element systematics of the volcanic rocks in the Bjørnesund and Ravns Storø

467 supracrustal belts are consistent with an oceanic island arc geodynamic setting (Cengija, 2010;

468 Szilas et al., 2012a). Neodymium and Hf isotope systematics indicate a depleted mantle source

469 for the amphibolites, suggesting that their protoliths were derived from a subarc mantle source.

470

471 4.1.8. The Mesoarchean (ca.3000 Ma) Tartoq supracrustal belt

472 The Tartoq supracrustal belt, also known as the Tartoq Group, is exposed in four areas, 473 namely the Nuuluk, Iterlak, Amitsuarsua, and Bikuben (Fig. 1) (Kisters et al., 2012; Szilas et al., 474 2013a). The belt is located in the Kvanefjord block of Windley and Garde (2009). Like other 475 Archean supracrustal belts, the Tartoq belt is composed of basaltic, gabbroic, ultramafic, and 476 sedimentary rocks (Fig. 10) (Higgins, 1968, 1990; Appel and Secher, 1984; Petersen, 1992;

477 Evans and King, 1993; Nutman and Kalsbeek, 1994; Nutman et al., 2004; Kisters et al., 2012;

478 Szilas et al., 2013a, 2014). The belt underwent at least four phases of deformation and 
479 heterogeneous metamorphism ranging from greenschist to lower granulite facies (Kisters et al., 480 2012). Contacts between different rock units are mainly structural and often marked by felsic 481 mylonites (Fig. 10d, e). These contacts often display multiple phases of folding, shearing, 482 carbonate and silica alteration, mylonitization, and transposition of the fabrics (Fig. 10f) (Polat 483 and Dziggel, 2011). Due to intense shearing, carbonate and silica alteration, and several 484 generations of folding, pillow structures in mafic volcanic rocks have largely been destroyed and 485 preserved only in several locations (Fig. 10a). Ultramafic rocks, mostly serpentinites, are also 486 strongly deformed and metamorphosed. The serpentinites are interpreted as lower arc cumulates 487 (Szilas et al., 2014). The belt has been intruded by the 2950-2990 Ma TTGs (Nutman and 488 Kalsbeek, 1994; Kisters et al., 2012). Some TTG sheets are tectonically imbricated with the 489 volcanic rocks in the belt (Kisters et al., 2012; Szilas et al., 2013a).

Extensive geochemical data reported by Szilas et al. (2013a, 2014) indicate that the Tartoq

491 belt formed in a Mesoarchean supra-subduction tectonic setting. On the basis of field 492 characteristics and geochemical data, Szilas and co-workers (2013a, 2014) interpreted the belt as 493 a dismembered supra-subduction ophiolite in a subduction-accretion complex. The TTGs were 494 derived mainly from partial melting of amphibolites in the subduction-accretion complex 495 (Kisters et al., 2012).

496

497 4.2. Layered ultramafic intrusions and anorthositic complexes

498 4.2.1. Layered ultramafic rocks in the Isukasia terrane

499 Tectonically intercalated slices of layered ultramafic-mafic rocks, including chromite500 bearing dunite, harzburgite, gabbro and minor anorthosite, occur within the Itsaq Gneiss 501 Complex of the Isuakasia terrane (Friend et al., 2002; Lowry et al., 2003). Friend et al. (2002) 
502 interpreted these ultramafic rocks as fragments of $>3800$ Ma abyssal peridotites dismembered

503 within an Eoarchean accretionary prism (Nutman et al., 1996; Friend et al., 2002).

\subsubsection{Layered anorthositic complexes}

The Archean craton of West Greenland contains the best-preserved, layered anorthositic

507 complexes in the world (Myers, 1985; Ashwal, 1993; Owens and Dymek, 1997; Dymek and 508 Owens, 2001; Windley and Garde, 2009; Polat et al., 2010, 2011a, 2011b; Hoffmann et al., 509 2012). These complexes consist mainly of anorthosite, leucogabbro, gabbro and ultramafic rocks 510 (Fig. 1) (Windley and Smith, 1974; Myers, 1985; Polat et al., 2009b, 2011a). The anorthositic 511 complexes consist of numerous conformable folded layers and lenses in the TTG gneisses of the 512 Tasiusarsuaq, Tre Brødre, Akia terranes and are typically associated with amphibolites (Windley 513 and Garde, 2009). A few slices of anorthosites are also found in the Mesoarchean Kapisilit 514 terranes (Friend and Nutman, 2005a). The TTG gneisses, amphibolites and anorthosite 515 complexes underwent polyphase deformation and amphibolite to granulite facies metamorphism 516 (Myers, 1985; Windley and Garde, 2009). They were deformed by an early phase of isoclinal 517 folding that was followed by isoclinal recumbent nappe formation, giving rise to kilometer-scale 518 fold interference patterns (Myers, 1985; Windley and Garde, 2009). The protoliths of the TTG 519 gneiss intruded the anorthosite complexes along shear zones and dispersed them as trains of 520 inclusions (Fig. 4e, f) (Myers, 1976; 1985; Windley and Garde, 2009). Figure 11 shows a tonalite 521 sheet that was emplaced along a thrust fault zone between two slices of anorthosite-leucogabbro 522 at Sinarssuk in the Fiskenæsset Complex. The best examples of anorthosite complexes in West 523 Greenland occur in the Fiskenæsset, Fiskefjorden, Nordland and Kapisilit regions (Myers, 1985; 
524 Owens and Dymek, 1997; Dymek and Owens, 2001; Windley and Garde, 2009; Polat et al., 525 2009b, 2010; Hoffmann et al., 2012). We focus on the Fiskenæsset anorthosite complex.

526 The Fiskenæsset Complex represents the largest and the most complete anorthositic 527 complex in West Greenland (Windley and Smith, 1976; Myers, 1985; Windley and Garde, 2009; 528 Polat et al., 2009b, 2010, 2011b, 2012). Although the complex underwent multiple phases of 529 ductile deformation and high-grade metamorphism, the original field relationships, and primary 530 igneous structures and textures are well preserved in numerous outcrops (Fig. 12) (Windley and 531 Smith, 1974; Myers, 1985; Polat et al., 2009b, 2010; 2011b). Igneous layering in the complex 532 consists of variable proportions of dunite, hornblende peridotite, hornblende pyroxenite, 533 hornblendite, gabbro, leucogabbro and anorthosite (Myers, 1985; Polat et al., 2009b, 2011b; 534 Polat, 2014). Field and petrographic studies indicate that the Fiskenæsset Complex was emplaced 535 into Mesoarchean oceanic crust as multiple sills and dykes of magma and crystal mush, forming 536 an association of $c a .550 \mathrm{~m}$-thick anorthosite, leucogabbro, gabbro and ultramafic layers (Myers, 537 1985; Polat et al., 2009b; 2010, 2011b). Zircon U-Pb dating of anorthosite and leucogabbro samples from the Majorqap qâva 539 section has yielded an age of 2936 \pm 13 Ma for the complex (Souders et al., 2013). A hornblendite 540 dyke at Majorqap qâva produced zircon U-Pb ages between 2950 to 2700 Ma (Keulen et al., 541 2010). Whole-rock samples of the anorthosite, leucogabbro, gabbro and ultramafic rocks on the 542 Island of Qeqertarssuatsiaq yielded 2973 \pm 28 Ma (MSWD=33) Sm-Nd and 2945 $\pm 36 \mathrm{Ma}$ 543 (MSWD=44) $\mathrm{Pb}-\mathrm{Pb}$ isotope regression ages (Polat et al., 2010). All these ages are collectively 544 consistent with the emplacement of the Fiskenæsset Complex into Mesoarchean oceanic crust 545 between 3000 and 2930 Ma (Escher and Myers, 1975; Myers, 1985; Polat et al., 2009b). 
Field relationships, $\mathrm{Nd}$ isotopic characteristics $\left(\varepsilon_{\mathrm{Nd}}=+3.3\right)$, mantle-like $\delta^{18} \mathrm{O}$ values, and 547 trace element systematics of mineral and whole-rock samples are collectively consistent with the 548 generation of the Fiskenæsset Complex as juvenile oceanic island crust (Polat et al., 2009b, 549 2010, 2011b, 2012; Polat and Longstaffe, 2014; Huang et al., 2014). The presence of overturned 550 igneous layers and regional scale recumbent folds, and thrust faults are collectively consistent 551 with a convergent plate margin tectonic setting for the Fiskenæsset Complex (Figs. 11, 12a).

Field, lithological, and mineralogical characteristics of the ca. 3000 Ma Naajat Kuuat 553 anorthosite complex are similar to those of the Fiskenæsset Complex (Hoffmann et al., 2012).

554 The trace element and Hf-Nd isotope systematics of the Naajat Kuuat Complex suggest a 555 juvenile island arc tectonic setting (Hoffmann et al., 2012). Amphibolites associated with the 556 Naajat Kuuat Complex display N-MORB and oceanic island arc trace element signatures, as do 557 the Fiskenæsset amphibolites (Polat et al., 2009b). The presence of igneous amphibole in both 558 complexes is consistent with hydrous sub-arc mantle sources.

559 Owens and Dymek (1997) and Dymek and Owens (2001) studied the geochemical 560 characteristics of the amphibolite facies Buksefjorden and granulite facies Nordland anorthosites 561 in the Akia and Tre Brødre terranes, respectively, and also concluded that these anorthosites 562 were derived from hydrous magmas.

563

564 5. Comparison of outcrop- and regional-scale structural patterns

$565 \quad$ Figure 13 shows a series of field photographs taken from a ca.1 kilometer long and 10 to 56620 meters wide shear zone between the Akuliaq supracrustal belt and the bordering TTG 567 gneisses in the Akuliaq Peninsula of the Paamiut region (Fig. 1; see also Fig. 4a-c) (GPS 568 coordinates: $\mathrm{N} 62^{\circ} 04^{\prime} 25.6^{\prime \prime}$ and $\left.\mathrm{W} 49^{\circ} 04^{\prime} 18.3^{\prime \prime}\right)$. For descriptive purposes this shear zone is 
569 informally called "the Akuliaq shear zone". The intensity of deformation along the shear zone is

570 heterogeneous. The Akuliaq Peninsula is located in the Paamiut terrane of Friend and Nutman

571 (2001) and in the Kvanefjord block of Windley and Garde (2009). Like other Archean

572 supracrustal belts in the region, this supracrustal belt underwent at least three phases of

573 deformation and amphibolite facies metamorphism (Glendenning, 2011; Hastie, 2011). Despite

574 polyphase deformation and amphibolite facies metamorphism, the belt preserves relict pillow 575 structures and intrusive relationships (Glendenning, 2011; Hastie, 2011).

The Akuliaq shear zone is a bifurcated shear zone and composed of two major rock types:

577 (1) fine- to coarse-grained, strongly folded mylonitic tonalitic gneiss (40-80\%); and (2) highly-

578 sheared mylonitic amphibolite (20-40\%) (Figs. 4a-c, 13). The fine-grained mylonitic tonalite is

579 interpreted as syn-tectonic melt intruding along the shear zone that developed in mafic volcanic 580 rocks (now amphibolite). Some parts of the Akuliaq shear zone resemble a small-scale tectonic 581 mélange in which folded, sheared and transposed tonalitic rocks are dispersed in a sheared 582 amphibolitic matrix (Fig. 13c-f). The Akuliaq shear zone contains isoclinal folds, refolded 583 isoclinal folds, and sheath folds displaying fold interference patterns resulting from the 584 superimposition of two and three generations of folds (Fig. 13). Truncation and transposition of 585 these folds resulted in hook-, fork-, spoon-, lens-, and eye-shaped tonalitic mylonites floating in 586 the amphibolitic matrix (Fig. 13c-f).

587 Figures 2 and 3 display regional-scale fold patterns in the Fiskefjord and Godthåbsfjord588 Ameralik regions, respectively. A comparison of the geometries of the outcrop-scale fold 589 patterns in the Akuliaq shear zone with those developed on regional scales reveal great 590 similarities between the two scales. These similarities suggest that Archean terranes in West 591 Greenland can be interpreted as collages of lithotectonic domains separated by heterogeneous 
592 shear zones and that the protoliths of the TTG gneisses were emplaced along the major shear 593 zones as syn-tectonic intrusions.

\section{Field evidence for melting of amphibolites and formation of TTGs}

A detailed discussion of the petrogenesis of Archean TTGs in West Greenland is beyond

597 the scope and objective of this contribution. The origin of these rocks were recently discussed in 598 several studies (see Steenfelt et al., 2005; Hiess et al., 2009, 2011; Nagel et al., 2012; Nutman et al., 2013; Huang et al., 2012; Hoffmann et al., 2011, 2014). The main objective of this section is

600

601

602 603 604 605 606 607 608 609 610

to present field evidence for the formation of felsic rocks (TTG and granites) through partial melting of amphibolites in shear zones. Although the felsic rocks show a wide range of compositions, for the sake of simplicity, we use the term "TTG" as a field description for all intrusive felsic rocks discussed in this section. Field evidence presented here was obtained during reconnaissance studies by the first author in the Mesoarchean Kapisilit and Tasiusarsuaq terranes (Figs. 14, 15).

Amphibolites occur either as large supracrustal belts (e.g., the Isua, Ivisaartoq, QussukBjørneøen supracrustal belts), or as numerous, 1 to 200 meters wide lenses within the TTG gneisses (Polat et al., 2009b, 2011a). The latter type of amphibolites share the deformation and metamorphic characteristics of the surrounding TTG gneisses and are likely to be remnants of earlier continuous layers that were sheared, folded, transposed and redistributed by deformation.

Field observations and petrographic studies suggest that the amphibolites were derived predominantly from basaltic (pillowed) protoliths. Gabbroic precursors are also recognized in several locations. The trace element characteristics of the basaltic and gabbroic protoliths are consistent with a subduction zone setting, suggesting that they represent fragments of Archean 
615 616

617 618 619

620 621

622 623

624 625 626 627 628 629 630 631 632 633 634 635 636 637

oceanic island arc crust (Garde, 2007; Polat et al., 2009b, 2009c, 2011a, 2011b; Szilas et al., 2012a, 2012b, 2013b).

As in many Archean migmatites (see Passchier et al., 1990; Sawyer, 2008), the amphibolites and TTGs in West Greenland display complex intrusive and structural relationships (Figs. 14, 15). Both the amphibolites and TTGs display heterogeneous deformation, ranging from slightly deformed to strongly mylonitized rocks (Chadwick, 1985; Crowley, 2003; Nutman et al., 2000, 2004; Friend and Nutman, 1991, 2005b). Lenses of deformed amphibolites occur as trails of conformable (parallel to the dominant foliation) inclusions around the folded gneisses (Figs. 2, 3). The presence of folded amphibolites that are cut by TTG veins in some outcrops indicate that the deformation and metamorphism of the basaltic protoliths had already taken place prior to the intrusion of these TTGs (Figs. 14, 15). The occurrence of several generations of cross-cutting TTG veins in some outcrops is attributed to multiple melting processes resulting from different tectonothermal events. In many outcrops, melting of the amphibolites appears to be coeval with isoclinal folding and shearing, whereas in other outcrops the amphibolites are cross cut by the TTG veins (Fig. 14a-c), reflecting several stages of melt formation and reworking of the amphibolites at various crustal depths (see Hoffmann et al., 2014). Where the amphibolites and gneisses are folded together, melts tend to concentrate in the fold hinges and along foliation planes (Fig. 15), indicating that these low-pressure areas acted as melt migration channels. Previous studies showed that the formation of Archean TTGs in West Greenland is closely associated with thrusting and isoclinal nappe forming events (Bridgwater et al., 1974; Friend et al., 1987, 1988, 1996; Myers, 1985; Nutman et al., 1993; Hanmer et al., 2002; Nutman and Friend, 2007; Windley and Garde, 2009; Kisters et al., 2012; Keulen et al., 2014), providing a genetic link between TTG formation and crustal thickening in response to tectonic collisions. 
In summary, we suggest that the basaltic and gabbroic protoliths of the supracrustal belts (now amphibolites) originated in oceanic island arcs. Then they were buried down to lower crustal depths by folding and thrusting, metamorphosed to amphibolite to granulite facies, or possibly to eclogite facies, and then underwent partial melting to produce TTGs (see Hoffmann et al., 2011, 2014; Nutman et al., 2015a). We are not claiming that all TTGs and granites in the Archean craton of West Greenland were generated by partial melting of amphibolites in thickened arcs. As discussed above, it is likely that these TTGs were generated by a combination of melting processes including melting of amphibolites in thickened arcs, melting of subducting slabs or oceanic plateaus (see Martin et al., 2014), and melting of sub-arc mantle peridotites. Recent models favor melting of thickened crust rather than subducting slabs (Nagel et al., 2012; Hoffmann et al., 2014).

Given that we cannot quantify the volume of TTGs produced by different melting processes, the relative proportions of TTGs originating from the melting of amphibolites in thickened arcs versus slab, oceanic plateau and sub-arc mantle peridotite melting are currently unknown. In addition, field and geochronological studies reveal that melting of amphibolites occurred during multiple tectonothermal events (Nutman et al., 1993; Nutman et al., 2007b); thus, individual TTG sheets that formed in a particular tectonothermal event cannot be easily distinguished (see Nutman et al., 1993; Friend and Nutman, 2005a).

Collectively, the presence of fold and thrust structures, major shear zones separating tectonic blocks (or terranes), accretionary prisms (e.g., the Isua, Storø, Tartoq supracrustal belts), and subduction zone and MORB trace element signatures (Polat et al., 2011a; Szilas et al., 2012a, 2012b, 2013b) are collectively consistent with the growth of the Archean craton in West Greenland along convergent plate boundaries (Figs. 16, 17). 


\section{Are supracrustal belts and anorthosite complexes in West Greenland fragments of}

\section{Archean ophiolites?}

In the framework of the theory of plate tectonics, ophiolites have been considered as the fragments of oceanic crust and uppermost mantle, recording the opening and closure of ancient oceans (Şengör, 1990; Şengör and Natal'in, 2004; Dilek and Furnes, 2014). Several recent studies (Kusky, 2004; Şengör and Natal'in, 2004; Dilek and Polat, 2008; Dilek and Furnes, 2011; Furnes et al., 2015) have shown that the classical Penrose ophiolite definition (Anonymous, 1972), due to its major limitations, should not be used as a guide to define ophiolites in polydeformed and metamorphosed Precambrian orogenic belts, particularly in Archean cratons. Dilek and Furnes (2011) redefined ophiolites as "suites of temporally and spatial associated ultramafic to felsic rocks related to separate melting episodes and processes of magmatic differentiation in particular tectonic environments". They divided ophiolites into two major types: (1) subductionrelated ophiolites forming in backarc, forearc and arc tectonic settings; and (2) subductionunrelated ophiolites being generated in rifted continental margins, mid-ocean ridges and oceanic plateaus. According to Furnes et al. (2015), the majority (>80\%) of Archean greenstone belts are subduction-related ophiolites.

The Altaids of Central Asia represent the largest Paleozoic accretionary complex in the world (Şengör et al., 1993, 2014; Şengör and Natal'in, 1996) and contain numerous slices of oceanic lithosphere (ophiolite). Şengör and Natal'in (2004) used the term "ophirag" to define the dismembered fragments of ophiolites that are tectonically dispersed in orogenic belts and suggested that the Altaids display many geological similarities to Archean granitoid-greenstone terranes. The Eoarchean to Mesoarchean supracrustal belts and layered anorthositic complexes in the Archean craton of West Greenland can be considered as Archean counterparts of the ophirags 
684 in the Altaids. These supracrustal belts and anorthositic complexes represent the tectonic slices

685 of mainly Archean suprasubduction zone oceanic crust corresponding to the fragments of 686 Archean subduction-related ophiolites of Furnes et al. (2015). Like the ophirags in the Altaids, 687 the supracrustal rocks and anorthositic complexes in the Archean craton of West Greenland do 688 not display a well-defined, continuous, narrow zones or map patterns (Figs. 1-3). Rather, they 689 tend to occur as variably oriented lenses, isoclinal folds, refolded isoclinal folds, sheath folds, 690 and fold hooks and forks in bifurcating shear zones. These fold and shear zone patterns reflect a

691

692 693 694 695

697

698 699 700 701 702 703 704 705 706 complex, heterogeneous, poly-phase deformation involving shearing, folding, truncation and transposition processes, resulting from several generations of overprinting deformation.

We do not mean that all Archean supracrustal belts are fragments of ophiolites. It is clear that Archean supracrustal belts that were emplaced on older continental crust such as the Neoarchean (2700 Ma) Kambalda supracrustal belt, Western Australia (Chauvel et al., 1985; Compston, et al., 1986; Lesher and Arndt, 1995) are not fragments of Archean ophiolite.

\section{Gravity-driven sinking, sagduction, dripping, delamination, and diapiric rising models}

Over the past forty years, one school of studies has proposed non-uniformitarian models to explain the geology of Archean cratons (e.g., Hamilton, 1998, 2013; Bédard, 2006; Robin and Bailey, 2009; Johnson et al., 2014; Thébaud and Rey, 2013; Moore and Webb, 2013; François et al., 2014; Gerya, 2014, and references therein). These models can collectively be called "gravitydriven sinking, sagduction, dripping, delamination, diapiric rising, crustal overturn, and heat pipe model". The model name has expanded with time, as the proponents invoked new names to explain their models. The majority of these models are based mainly on numerical simulations rather than field observations. Although numerical simulations can provide significant insight 
707 into understanding Archean tectonic processes (e.g., Hynes, 2014), given that their outcome 708 strongly depends upon input parameters and boundary conditions set for the models, they need to 709 be tested against geological observations (see Burke, 2011). These models assume that Archean 710 greenstone belts were generated as either continental flood basalts (e.g., Thebaud and Rey, 2013) 711 or oceanic plateaus (Bédard, 2006), or both. Because of density difference between mafic to 712 ultramafic greenstones and felsic continental crust (TTG), these models assume that greenstones 713 sink, metamorphose and melt to generate TTGs. The rise of TTG melts as diapirs generates basin 714 and dome structures (Thebaud and Rey, 2013). Continued melting of greenstones at the base of 715 the crust generates more TTG melts and denser restite (e.g., pyroxenite, eclogite) that eventually 716 delaminate and recycle into the mantle (Bédard, 2006).

717 These models have no modern and Archean analogs and a number of major shortcomings. 718 First, they are inconsistent with overwhelming field, structural, geochronological, and 719 geochemical data obtained over the last four decades from the Archean craton of West Greenland 720 specifically, and with those collected from other Archean cratons in general (e.g., Sleep, 1992; 721 Stott, 1997; de Wit, 1998; Percival et al., 2006, 2012; Kusky et al., 2014; Furnes et al., 2013, 722 2015). Second, they are based on the assumption that the geological properties of Archean 723 continents were very different from those of modern Earth. However, Burke and Kidd (1978) 724 and Burke et al. (1986) showed that this assumption is likely to be incorrect. Third, they require 725 the presence of pre-existing continental crust (protocrust) onto which a thick pile of Archean 726 volcanic rocks were emplaced (Robin and Bailey, 2009), but they do not explain how the 727 protocrust was generated in the first place. No pillow basalts have ever been recognized in 728 continental flood basalts. Fourth, they cannot readily explain the recycling of water into the 729 Archean upper mantle (see Polat et al., 2012; Polat, 2012), because Archean flood basalts 
730

731

732

733

734

735

736

737

738

739

740

741

742

743

744

745

746

747

748

749

750

751

752

emplaced on continental crust would not have been as hydrated as those forming in oceanic crust. Petrogenesis of Archean layered anorthosite complexes requires hydrous melts (Polat et al., 2009b, 2012; Rollinson et al., 2010; Hoffmann et al., 2012). Subduction of altered oceanic crust is the most efficient mechanism for recycling water into the mantle (Savage, 2012). Fifth, Archean continental crust could not grow laterally and TTGs could not have been generated over millions of years without subduction of hydrated oceanic crust (see Campbell and Taylor, 1983; Burke, 2011; Arndt, 2013; Martin et al., 2014). Sixth, over 1000 km long, fault-bounded lithotectonic assemblages (e.g., the Superior Province, see Sleep, 1992; Stott, 1997; Percival et al., 2006, 2012) cannot be generated by sinking, sagduction, dripping, delamination, diapiric rising and crustal overturn processes. Seventh, these models cannot account for the presence of boninites, adakites, high-magnesian andesites, arc picrites, and high-Nb basalts in Archean greenstone belts (Polat and Kerrich, 2006). Eighth, these models cannot explain similarities in the formation of metallogenic ore deposits and their host rock associations in the Archean and Phanerozoic (Kerrich and Wyman, 1990; Kolb et al., 2013; Garde et al., 2012).

Table 1 presents a list of major Precambrian layered mafic to ultramafic intrusions (e.g., Bushveld, Stillwater), and Phanerozoic ophiolites (e.g., Oman, Bay of Island; Troodos), oceanic plateaus (Ontong Java, Caribbean), and continental flood basalts (e.g., Siberian traps, Deccan traps, Parana basalts). Despite their great thickness and density, they have not sunk into the lower crust and overturned yet, suggesting that the "sinking, sagduction, dripping, delamination, diapiric rising and crustal overturn" processes are not suitable for the Earth, at least since the mid to late Archean.

In summary, plate tectonics has not only shaped the evolution of the Earth's mantle and crust since the early Archean (Burke, 2011; Nutman et al., 2015a) but also has played a major 
753 role in biological evolution and climate change. The theory of plate tectonics provides a unifying

754 and self-consistent explanation for the origins of structures, and magmatic, metamorphic and 755 sedimentary rocks in the Earth's crust (Polat, 2014). It also provides the most efficient and 756 simplest mechanism to explain heat dissipation from the mantle, hydration and recycling of the 757 oceanic crust, formation of continental rifts, orogenic belts, sedimentary basins, accretionary 758 complexes, fold and thrust belts, ophiolites and metamorphic belts, and the geochemical 759 compositions of igneous rocks (Şengör, 1990; Hofmann, 1997; Kellogg et al., 1999; Sobolev et 760 al., 2000; Schaefer et al., 2002; Frisch et al. 2011). The non-uniformitarian models assume a 761 static early Earth despite higher mantle temperatures in the Archean. In contrast, the 762 uniformitarian plate tectonic models propose a dynamic, permobile early Earth (Burke et al., 763 1976) and make sense of a huge amount of structural, lithological, geochemical, 764 geochronological and petrological data obtained from Archean greenstone-granitoid terranes in 765 all major continents over the past forty years (Polat et al., 2011a; Percival et al., 2012; Arndt, 766 2013; Kusky et al., 2014; Turner et al., 2014, Backeberg et al., 2014; Wang et al., 2013).

\section{Structural and melting patterns in the Mesozoic Sulu orogen}

A detailed discussion of the tectonic evolution of the Mesozoic Sulu orogenic belt, China,

770 is beyond the scope and objective of this study. The main objective of this section is to compare

771 the style of deformation and formation of felsic rocks through partial melting of mafic

772 metamorphic rocks in the newly-discovered outcrops in the Yangkou Bay/General's Hill area of

773 the Sulu orogenic belt (Figs. 18, 19) (Wang et al., 2010, 2014), with those described from the 774 Archean craton of West Greenland (Figs. 4-17). 
The Mesozoic Sulu orogenic belt is the eastern extension of the Qinling-Dabie orogenic 776 belt and exposed mainly in the Shandong Peninsula (Meng and Zhang, 2000; Wang et al., 2010, 777 2014). The belt is well known for its ultrahigh pressure (UHP) metamorphic rocks, consisting 778 mainly of coesite-bearing eclogites. The belt originated through a continent-continent collision 779 between the Yangtze and North China cratons (Wang et al., 2010, 2014). The timing of the 780 collision, and structural, metamorphic and magmatic characteristics of the Sulu subduction 781 system are subjects of recent extensive research (Cheng et al., 2000, Liu et al., 2005; Hacker et 782 al., 2009; Ratschbacher et al., 2006; Wang et al., 2010, 2014). The subduction of Paleozoic 783 oceanic lithosphere beneath the North China craton resulted in the underthrusting of the leading 784 edge of the Yangtze craton beneath the Dabie-Sulu orogen and the North China craton and 785 intervening Qinling microcontinent in some parts of the orogen. This subduction led the 786 formation of UHP assemblages in the Sulu orogenic belt (Wang et al., 2010). The Sulu orogenic 787 belt consists predominantly of greenschist to amphibolite facies metamorphic rocks, with rare 788 late Triassic coesite-bearing eclogites such as those exposed at Yankou Bay (Ames et al., 1996; 789 Liou and Zhang, 1996). Geochronological studies of the UHP metamorphic rocks have shown 790 that the peak metamorphism took place at about $230 \mathrm{Ma}$ (see Wang et al., 2014).

791 Wang et al. (2014) carried out detailed structural, petrographic, geochemical and 792 geochronological studies on retrogressed, migmatitic eclogites at General's Hill, near 793 Diaolongzui village, about $2 \mathrm{~km}$ south of Diaolongzui, Yangkou Bay (Figs. 18, 19). The 794 exposures of the General's Hill eclogite are characterized by strongly foliated, sheared and 795 complexly folded eclogite and amphibolite dispersed within partial melt veins and layers of 796 felsic leucosome (Fig. 20). Wang et al. (2010) showed that the partial melting of eclogites and 
797 their retrogressed counterparts (amphibolites) was syn-tectonic and melts migrated along micro798 veins, foliation planes, fold hinges and extensional shear planes (Fig. 19).

799 Structures and relationships between the host rocks and melts at General's Hill are 800 remarkably similar to those from the much older rocks in Greenland, suggesting that similar 801 physical processes were operating in the genesis of ca. 2.8-3.0 Ga rocks in Greenland, and 802 Mesozoic rocks in the Sulu orogen. The General's Hill outcrops show an eclogitic migmatite, 803 where the light-colored rocks in Figure 20 are the leucosome, and the black to red-colored rocks 804 are the retrogressed eclogite forming melanosome and restite. Detailed studies (e.g., Wang et al., 805 2014) show that the melts first form as small droplets along crystal grain boundaries, then merge 806 along microfaults and shear zones to accumulate in areas where the stress is low, then merge to 807 form large channels where the melt can migrate to higher levels in the crust. Similar to the 808 examples from Greenland (Figs. 14, 15), at General's Hill the melting has enhanced the 809 deformation, and the deformation has helped to concentrate the melts in low strain zones such as 810 fold hinges, extensional boudin necks, until eventually elastic-style folds become isolated from 811 each other in melt channels where the leucosome flows and merges with other melt channels to 812 form larger dikes (Fig. 20).

813 Geochemical analysis of the felsic rocks at General's Hill indicates that they are dacitic to 814 rhyolitic in composition with a calc-alkaline arc affinity. A wide spectrum of REE patterns and 815 variations in major and trace element abundances in both the felsic leucosome and mafic residue 816 are consistent with multiple melting events (Wang et al., 2014). Compositionally, the felsic rocks 817 are similar to the upper continental crust, suggesting a genetic link between subduction zone 818 geodynamic and petrogenetic processes and the origin of continental crust. 
The folds in the outcrops of Diaolongzui display a variety of geometries and interference

820

821

822

823

824

825

826

827

828

829

830

831

832

833

834

835

836

837

838

839

840

841

patterns, including refolded, transposed and isolated isoclinal folds, and rootles, hook- and fork-

shaped folds (Figs. 19, 20). As shown in Figures 2-17, the folding style and mechanisms of melt extraction in the Sulu orogenic belt and those in the Archean craton of West Greenland are remarkably similar, suggesting that they were produced by similar geological processes.

\section{Conclusions}

On the basis of field observations presented in this contribution, and structural, geochronological and geochemical data obtained from the Archean craton of West Greenland over past four decades, the following conclusions and implications are drawn:

1. The Archean craton of West Greenland is characterized by Eoarchean (3850 Ma) to Neoarchean (2550 Ma) terranes (tectonic blocks) separated by mylonitic shear zones that represent suture zones along which Archean oceans were closed. The final tectonic assembly of the craton took place through multiple, horizontal accretionary processes in the late Archean between 2750 and 2600 Ma.

2. The tectonic terranes are composed mainly of TTG gneisses and granites (ca. 80\%), and supracrustal rocks (greenstone belts) and layered anorthositic complexes (ca. 20\%). Except for the late- to post-tectonic granites (e.g., the ca. 2550 Ma Qôrqut granites), all these rock types underwent multiple phases of deformation and greenschist to granulite facies metamorphism at convergent plate boundaries, consistent with the growth of Archean continental crust mainly in subduction zones.

3. The supracrustal belts represent relict accretionary prisms (e.g., the Eoarchean Isua and Mesoarchean Tartoq belts) or fragments of island arc, forearc or backarc oceanic crust (e.g., 
Mesoarchean Ivisaartoq, Qussuk-Bjørneøen belts) are interpreted as fragments of Archean $843 \quad$ ophiolites.

844 4. The layered anorthositic complexes (e.g., the Fiskenæsset Complex) were derived from 845 hydrous mantle sources and formed as suprasubduction zone oceanic crust.

846 5. The style of deformation (e.g., fold patterns, shearing) on centimetre to metre scale shear 847 zones is similar to those developed on regional scale, suggesting that Archean terranes can 848 be defined as collages of lithotectonic assemblages. The presence of widespread shearing 849 throughout the terranes is consistent with the growth of the Archean craton of West 850 Greenland by tectonic accretion. The map patterns of the supracrustal rocks in the Archean craton West Greenland are similar to those in the Paleozoic Altaid orogenic belt.

6. Partial melting of supracrustal belts in thickened arcs played an important role in the 853 formation of Archean continental crust.

8547 . The style of deformation and generation of felsic rocks through melting of mafic rocks in the 855 Phanerozoic is similar.

858

8. Tectonic, magmatic, and metamorphic processes and field relationships recorded in the Archean craton of West Greenland, as well as those in other Archean cratons and postArchean orogenic belts, are collectively inconsistent with the operation of nonuniformitarian, gravity-driven sinking, sagduction, dripping, delamination, diapiric rising, crustal overturn, and heat pipe models over past four billion years in Earth history. 
872

873

874 875 876 877 878 879 880 881 882 883 885

\section{Acknowledgements}

This is a contribution of NSERC grant 250926 to A. Polat, and National Natural Science Foundation of China grants 41272225, 40802045 to L. Wang. We thank T.M. Kusky for discussion on Archean tectonics and reviewing an initial draft of the paper. Reviewers Adam A. Garde and Kristoffer Szilas are acknowledged for their incisive and constructive comments, resulting in significant improvements to the paper. Field work was supported by the Bureau of Minerals and Petroleum in Nuuk and the Geological Survey of Denmark and Greenland (GEUS). This paper is submitted with the permission of the GEUS.

\section{References}

775 Adam, J., Rushmer, T., O’Neil, J., Francis, D., 2012. Hadean greenstones from the Nuvvuagittuq 876 fold belt and the origin of the Earth's early continental crust. Geology 40, 363-366.

77 Allaart, J.H., 1976. The pre-3760 m.y. old supracrustal rocks of the Isua Area, Central West 878 Greenland, and the associated occurrence of quartz-banded ironstone. In: B.F., Windley (Ed.), The Early History of the Earth. John Wiley and Sons, London, pp. 177-189.

Ames, L., Zhou, G., Xiong, B., 1996. Geochronology and geochemistry of ultra-high pressure metamorphism with implications for collision of the Sino-Korean and Yangtze cratons, central China. Tectonics 15, 472-489.

Amiguet, E., Reynard, B., Caracas, R., Van de Moortele, Hilairet, N., Wang, N., 2012. Creep of phyllosilicates at the onset of plate tectonics. Earth and Planetary Science Letters 345-348, $142-150$.

Andersen, L.S., 1974. Rapport over geologien mellem Frederkshåbs Isblink og Quvnilik Fjord Vest Grønland. Unpublished Ph.D. thesis, Copenhagen University, 259 pp. 
Andersen, L.S., Friend, C.R.L., 1973. Structure of the Ravns Storø amphibolite belt in the Fiskenæsset region. Rapport Grønlands Geologiske Undersøgelse 51, 37-40.

Anonymous, 1972. Penrose field conference on Ophiolites. Geotimes 17, 24-25.

Appel, P.W.U., Fedo, C.M., Moorbath, S., Myers, J.S., 1998. Recognizable primary volcanic and sedimentary features in a low-strain domain of the highly deformed, oldest known $(\approx 3.7-3.8$ Gyr) Greenstone Belt, Isua, West Greenland. Terra Nova 10, 57-62.

Appel, P.W.U., Polat, A., Frei, R., 2009. Dacitic ocelli in mafic lavas, 3.8-3.7 Ga Isua greenstone belt, West Greenland: Geochemical evidence for partial melting of oceanic crust and magma mixing. Chemical Geology 258, 105-124.

Appel, P.W.U., Secher, K., 1984. On gold mineralization in the Precambrian Tartoq Group, SW Greenland. Journal of the Geological Society of London 141, 273-278.

Arndt, N.T., 2013. The formation and evolution of the continental crust. Geochemical Perspectives 2, 405-528.

Ashwal, L.D. 1993. Anorthosites. Springer-Verlag, Berlin, 422 pp.

Baadsgaard, H., Nutman, A.P., Bridgwater, D., 1986. Geochronology and isotopic variation of the early Archean Amitsoq gneisses of the Isukasia area, southern West Greenland. Geochimica et Cosmochimica Acta 50, 2173-2183.

Backeberg, N.R., Rowe, C.D., van Hinsberg, V.J., Bellefroid, E.J., 2014. Structural and metamorphic evidence for Mesoarchaean subduction in the Finlayson Lake greenstone belt, Superior Province, Ontario. Precambrian Research 249, 100-114.

Bédard, J.H., 2006. A catalytic delamination-driven model for coupled genesis of Archaean crust and sub-continental lithospheric mantle. Geochimica et Cosmochimica Acta 70, 1188-1214. 
Berthelsen, A., Henriksen, N., 1975. Geological map of Greenland, 1:100,000 Ivittuut 61 V.1 Syd (with description), Geological Survey of Greenland, Copenhagen.

Bridgwater, D., McGregor, V.R., Myers, J.S., 1974. A horizontal tectonic regime in the Archaean of Greenland and its implications for early crustal thickening. Precambrian Research 1, 179-197.

Bridgwater, D., Keto, L., McGregor, V.R., Myers, J.S. 1976. Archean gneiss complex of Greenland. In: Escher A., Watt, W.S., (Eds.), Geology of Greenland. Copenhagen, Geological Survey of Greenland, 21-75.

Burke, K., 2011. Plate tectonics, the Wilson cycle, and mantle plumes: geodynamics from the top. Annual Review of Earth and Planetary Sciences 39, 1-29.

Burke, K., Dewey, J., Kidd, W.S.F., 1976. Dominance of horizontal movements, arc and microcontinental collisions during the later permobile regime. In: Windley, B.F. (Ed.), The Early History of the Earth. Wiley, London, pp. 113-129.

Burke, K., Kidd, W.S.F., 1978. Were Archean continental geothermal gradients much steeper than those of today? Nature 272, 240-241.

Burke, K, Kidd. W.S.F., Kusky T.M., 1986. Archean foreland basin tectonics in the Witwatersrand, South Africa. Tectonics 5, 439-56.

Campbell, I.H., Taylor, S.R., 1983. No water, no granites - no granites, no continents. Geophysical Research Letters 10, 1061-1064.

Chauvel, C., Dupre, B., Jenner, G., 1985. The Sm-Nd age of Kambalda volcanic is 500 Ma too old. Earth and Planetary Science Letters 74, 315-324.

Cengija, S., 2010. Geochemical and Petrological Analysis of Ikatoq and Bjornesund Greenstone belts in Southern Greenland. Unpublished MSc thesis, University of Windsor, 58 pp. 
933 Chadwick, B., 1985. Contrasting styles of tectonism and magmatism in the late Archean crustal 934 of the northeastern part of the Ivisârtoq region, inner Godthåbsfjord, southern west Greenland. 935 Precambrian Research 27, 215-238.

936 Chadwick, B., 1990. The stratigraphy of a sheet of supracrustal rocks within high-grade 937 orthogneisses and its bearing on Late Archaean structure in southern West Greenland. Journal 938 of the Geological Society, London, 147, 639-652.

939 Cheng, Y.Q., Liu, D.Y., Williams, I.S., Jian, P., Zhuang, Y.X., Gao, T.S., 2000. SHRIMP U-Pb 940 dating of zircons of a dark-colored eclogite and a garnet-bearing gneissic-granitic rock from 941 Bixiling, eastern Dabie area, Anhui Province: isotope chronological evidence of 942 Neoproterozoic UHP metamorphism. Acta Geologica Sinica 74, 748-765.

943 Compston, W., Williams, I.S., Campbell, I.H., Gresham, J.J., 1986. Zircon xenocrysts from the 944 Kambalda volcanic: age constraints and direct evidence for older continental crust below the $945 \quad$ Kambalda-Norseman greenstones. Earth and Planetary Science Letters 76, 299-311.

946 Crowley, J.L., 2002. Testing the model of late Archean terrane accretion in southern West 947 Greenland: a comparison of the timing of geological events across the Qarliit nunaat fault, 948 Buksefjorden region. Precambrian Research 116, 57-79.

949 Crowley, J.L., 2003. U-Pb geochronology of 3810-3630 Ma granitoid rocks south of the Isua 950 greenstone belt, southern West Greenland. Precambrian Research 126, 235-257.

951 de Wit, M.J., 1998. On Archean granites, greenstones, cratons, and tectonics: does the evidence 952 demand a verdict? Precambrian Research 91, 181-226.

953 de Wit, M., Furnes, H., 2013. Earth's oldest preserved unconformity — Prospect of a beginning 954 in the tectono-sedimentary continental cycle? Gondwana Research 23, 429-435. 
955 Dilek, Y., Furnes, H., 2011. Ophiolite genesis and global tectonics: Geochemical and tectonic 956 fingerprinting of ancient oceanic lithosphere. Geological Society of America Bulletin 123, $957 \quad 387-411$.

958 Dilek, Y., Furnes, H., 2014. Ophiolites and their origins. Elements 10, 93-100.

959 Dilek, Y., Polat, A., 2008. Suprasubduction zone ophiolites and Archean tectonics. Geology 36, $960 \quad 431-432$.

961 Dostal, J., Mueller, W.U., 2013. Deciphering an Archean mantle plume: Abitibi greenstone belt, 962 Canada. Gondwana Research 23, 493-505.

963 Dyck, B., Reno, B.L., Kokfelt, T.F., 2015. The Majorqaq Belt: A record of Neoarchaean 964 orogenesis during final assembly of the North Atlantic Craton, southern West Greenland. 965 Lithos 220-223, 253-271.

966 Dymek, R.F., Owens, B.R., 2001. Chemical assembly of Archean anorthosites from amphibolite967 and granulite-facies terranes, SW Greenland. Contributions to Mineralogy and Petrology 141, $968 \quad 513-528$.

969 Dziggel, A., Diener, J.F.A., Kolb, J., Kokfelt, T.F., 2014. Metamorphic record of accretionary 970 processes during the Neoarchean: The Nuuk region, Southern West Greenland. Precambrian $971 \quad$ Research 242, 22-38.

972 Ernst, R.E., Bleeker, W., Söderlund, U., Kerr, A.C., 2013. Large Igneous Provinces and 973 supercontinents: Toward completing the plate tectonic revolution. Lithos 174, 1-14.

974 Escher, J.C., Myers, J.S., 1975. New evidence concerning the original relationships of early 975 Precambrian volcanic and anorthosites in the Fiskenæsset region, southern West Greenland. 976 Grønlands Geologiske Undersøgelse Rapport 75, 72-76. 
977 Escher, J.C., Pulvertaft, T.C.R., 1995. Geological map of Greenland, 1: 2500 000. Copenhagen:

978 Geological Survey of Denmark.

979 Evans, D.M., King, A.R., 1993. Sediment and shear-hosted gold mineralization of the Tartoq

980 Group supracrustals, southwest Greenland. Precambrian Research 62, 61-82.

981 Fedo, C.M., 2000. Setting and origin for problematic rocks from the $>3.7$ Ga Isua greenstone

982 belt, southern west Greenland: Earth's oldest coarse clastic sediments. Precambrian Research $983 \quad 101,69-78$.

984 Frisch, W., Meschede, M., Blakey, R., 2011. Plate Tectonic: Continental Drift and Mountain 985 Building. Springer-Verlag, Berlin, pp. 212.

986 Frei, R., Polat, A., Meibom, A., 2004. The Hadean upper mantle conundrum: evidence for source 987 depletion and enrichment from $\mathrm{Sm}-\mathrm{Nd}$, $\mathrm{Re}-\mathrm{Os}$, and $\mathrm{Pb}$ isotopic compositions in $3.71 \mathrm{~Gy}$ 988 boninite-like metabasalts from the Isua Supracrustal belt, Greenland. Geochimica et 989 Cosmochimica Acta 68, 1645-1660.

990 Friend, C.R.L., 1975. The geology and geochemistry of the Preketilidian basement complex in 991 the Ravns Storø area, Fiskenæsset region, southern West Greenland. Unpublished Ph.D. 992 thesis, University London, 233 pp.

993 Friend, C.R.L., Bennett, V.C., Nutman, A.P., 2002. Abyssal peridotites > 3800 Ma from 994 southern West Greenland: field relationships, petrography, geochronology, whole-rock and 995 mineral chemistry of dunite and harzburgite inclusions in the Itsaq Gneiss Complex. 996 Contributions to Mineralogy and Petrology 143, 71-92.

997 Friend, C.R.L., Nutman, A.P., 1991. Refolded nappes during late Archean terrane assembly, 998 Godthåbsfjord, southern West Greenland. Journal of the Geological Society, London, 148, $999 \quad 507-519$. 
1000 Friend, C.R.L., Nutman, A.P., 2001. U-Pb zircon study of tectonically-bound blocks of 294010012840 Ma crust with different metamorphic histories, Paamiut region, South-West Greenland: 1002 Implications for the tectonic assembly of the North Atlantic craton. Precambrian Research $1003 \quad 105,143-164$.

1004 Friend, C.R.L., Nutman, A.P., 2005a. New pieces to the Archean jigsaw puzzle in the Nuuk 1005 region, southern West Greenland: steps in transforming a simple insight into a complex 1006

Friend, C.R.L., Nutman, A.P., McGregor, V.R., 1987. Late-Archaean tectonics in the Færingehavn-Tre Brødre area, south of Buksefjorden, southern West Greenland. Journal of the Geological Society, London, 144, 369-376.

Friend, C.R.L., Nutman, A.P., McGregor, V.R., 1988. Late Archean terrane accretion in the Godthåb region, southern West Greenland. Nature 335, 535-538.

Friend, C.R.L., Nutman, A.P., Baadsgaard, Kinney, P.D., McGregor, V.R., 1996. Timing of late Archean terrane assembly, crustal thickening and granite emplacement in the Nuuk region, southern West Greenland. Earth and Planetary Science Letters 142, 353-365.

Friend, C.R.L., Nutman, A.P., Bennett, V.C., Norman, M.D., 2008. Seawater-like trace element signatures $(\mathrm{REE}+\mathrm{Y})$ of Eoarchean chemical sedimentary rocks from southern West Greenland, and their corruption during high-grade metamorphism. Contributions to Mineralogy and Petrology 155, 229-246. 
1022 François, C., Philippot, P., Rey, P., Rubatto, D., 2014. Burial and exhumation during Archean 1023 sagduction in the East Pilbara Granite-Greenstone Terrane. Earth and Planetary Science 1024 Letters 396, 235-251.

1025 Furnes, H., de Wit, M., Staudigel, H., Rosing, M., Muehlenbachs, K., 2007. A vestige of Earth's 1026 oldest ophiolite. Science 315, 1704-1707.

1027 Furnes, H., de Wit, M.J., Robins, B., 2013. A review of new interpretations of the 1028

Furnes, H., Dilek, Y., de Wit, M., 2015. Precambrian greenstone sequences represent different

Furnes, H., Rosing, M., Dilek, Y., de Wit, M., 2009. Isua supracrustal belt (Greenland) -A vestige of a $3.8 \mathrm{Ga}$ suprasubduction zone ophiolite, and the implications for Archean geology.

$$
\text { Lithos 113, 115-132. }
$$

$$
\text { ophiolite types. Gondwana Research 27, 649-685. }
$$

Garde, A.A., 1990. Thermal granulite-facies metamorphism with diffuse retrogression in Archaean orthogneisses, Fiskefjord, southern West Greenland. Journal of Metamorphic Geology 8, 663-682.

Garde, A.A., 1997. Accretion and evolution of an Archaean high-grade grey gneiss-amphibolite complex: the Fiskefjord area, southern West Greenland. Bulletin Grønlands Geologiske Undersøgelse 177, 115 pp.

Garde, A.A., 2007. A Mid-Archean island arc complex in the eastern Akia terrane, 1043 Godthåbsfjord, southern West Greenland. Journal of the Geological Society, London, 164, $565-579$. 
1044 Garde, A.A., Dyck, B., Esbensen, K., Johansson, L., Möller, C., 2014. The Finnefjeld domain, 1045 Maniitsoq structure, West Greenland: Differential rheological features and mechanical 1046 homogenisation in response to impacting? Precambrian Research 255, 791-808.

1047 Garde, A.A., Whitehouse, M., Christensen, R., 2012. Mesoarchean epithermal gold 1048 mineralization preserved at upper amphibolite-facies grade, Qussuk, southern West 1049 Greenland. Economic Geology 107, 881-908.

1050 Gerya, T., 2014. Precambrian geodynamics: Concepts and models. Gondwana Research 25, 4421051463.

1052 Glendenning, M., 2011. Mapping and petrographic analysis of the lithology of Akuliaq 1053 Peninsula, Paamiut Region, Southwest Greenland. Geological Survey of Denmark and 1054 Greenland, Ministry of Climate and Energy Report 2011/114, 79-115.

1055 Hacker, B.R., Wallis, S.R., McWilliams, M.O., Gans, P.B., 2009. ${ }^{40} \mathrm{Ar} /{ }^{39} \mathrm{Ar}$ constraints on the 1056 tectonic history and architecture of the ultrahigh-pressure Sulu orogen. Journal of 1057 Metamorphic Geology 27, 827-844.

1058 Hall, R.P., 1980. The tholeiitic and komatiitic affinity of Malene metavolcanic amphibolites 1059 from Ivisaartoq, southern West Greenland. Grønlands Geologiske Undersøgelse Rapport 97, $106020 \mathrm{pp}$.

1061 Hall, R.P., Friend, C.R.L., 1979. Structural evolution of the Archean rocks in Ivisârtoq and the 1062 neighbouring inner Godthåbsfjord region, southern West Greenland. Geology 7, 311-315.

1063 Hamilton, W.B., 1998. Archean magmatism and deformation were not products of plate 1064 tectonics. Precambrian Research 91, 143-179.

1065 Hamilton, W.B., 2013. Evolution of the Archean Mohorovičić discontinuity from a 1066 synaccretionary 4.5 Ga protocrust. Tectonophysics 609, 706-733. 
1067

1068

1069

1070

1071

1072

1073

1074

1075

1076

1077

1078

1079

1080

1081

1082

1083

1084

1085

1086

1087

1088

Hanmer, S., Hamilton, M.A., Crowley, J.L., 2002. Geochronological constraints on Paleoarchean thrust-nappe and Neoarchean accretionary tectonics in southern West Greenland. Tectonophysics 350, 255-271.

Hanmer, S., Greene D.C., 2002. A modern structural regime in the Paleoarchean ( 3.64); Isua Greenstone Belt, southern West Greenland. Tectonophysics 346, 201-222.

Hastie, E.C.G., 2011. Mapping and Structural Analysis of the Akuliaq Peninsula, near Paamuit, SW Greenland. Geological Survey of Denmark and Greenland, Ministry of Climate and Energy Report 2011/114, 49-78.

Hawkins, J.W., 2003. Geology of supra-subduction zones: Implications for the origin of ophiolites. In: Dilek, Y., Newcomb, S., (Eds.), Ophiolite Concept and the Evolution of Geological Thought. Geological Society of America Special Paper 373, 227-268.

Hiess, J., Bennett, V.C., Nutman, A.P., Williams, I.S., 2009. In situ U-Pb, O and Hf isotopic compositions of zircon from Eoarchaean tonalite and felsic volcanic rocks, Itsaq Gneiss Complex, southern West Greenland: New constraints on the source materials for the early crust. Geochimica et Cosmochimica Acta 73, 4489-4516.

Hiess, J., Bennett, V.C., Nutman, A.P., Williams, I.S., 2011. Archaean fluid-assisted crustal cannibalism recorded by low $\delta^{18} \mathrm{O}$ and negative $\varepsilon_{\mathrm{Hf}}(\mathrm{T})$ isotopic signatures of West Greenland granite zircon. Contributions to Mineralogy and Petrology 161, 1027-1050.

Higgins, A.K., 1968. The Tartoq Group on Nuna Qaqertoq and in the Iterdlak area, South-West Greenland: Rapport Grønlands Geologiske Undersøgelse, 17 pp.

Higgins, A.K., 1990. Descriptive text to 1:100000 sheets Neria 61 V.1 N and Midternæs 61 V.2 N. Geological Survey of Greenland, 23 pp. 
Hofmann, A.W., 1997. Mantle geochemistry: the messages from oceanic volcanism. Nature 385, 219-229.

Hoffmann, J.E., Münker, C., Næraa, T., Rosing, M.T., Herwartz, D., Garbe-Schönberg, D., Svahnberg, H., 2011. Mechanisms of Archean crust formation inferred from high-precision HFSE systematics in TTGs. Geochimica et Cosmochimica Acta 75, 4157-4178.

Hoffmann, J.E, Münker, C., Polat, A., König, S., Mezger, K., Rosing, M.T., 2010. Highly depleted Hadean mantle reservoirs in the sources of early Archean arc-like rocks, Isua supracrustal belt, SW-Greenland. Geochimica et Cosmochimca Acta 74, 7236-7260.

Hoffmann, J.E., Svahnberg, H., Piazolo, S., Scherstén, A., Münker, C., 2012. The geodynamic evolution of Mesoarchean anorthosite complexes inferred from the Naajat Kuuat Complex, southern West Greenland. Precambrian Research 196-197, 149-170.

Hoffmann, J.E., Nagel, T.J., Münker, C., Næraa, T., Rosing, M.T., 2014. Constraining the process of Eoarchean TTG formation in the Itsaq Gneiss Complex, southern West Greenland. Earth and Planetary Science Letters 388, 374-386.

Hollis, J.A., (Ed.) 2005. Greenstone belts in central Godthåbsfjord region, southern West Greenland: Geochemistry, geochronology and petrology arising from 2004 field work, and digital map data. Danmarks Og Grønlands Geologiske Undersøgelse Rapport 42, 214 pp.

Hollis, J.A., van Gool, J.A.M., Steenfelt, A., Garde, A.A., 2004. Greenstone belts in the central Godthåbsfjord region, southern West Greenland: Preliminary results from field work in 2004. Danmarks Og Grønlands Geologiske Undersøgelse Rapport 110, 110 pp.

Huang, H., Fryer, B.J., Polat, A., Pan, Y., 2014. Amphibole, plagioclase and clinopyroxene geochemistry of the Archean Fiskenæsset Complex at Majorqap qâva, southwestern 
Greenland: Implications for Archean petrogenetic and geodynamic processes. Precambrian Research 247, 64-91.

1113 Huang, H., Polat, A., Fryer, B.J., Appel, P.W.U., Windley, B.F., 2012. Geochemistry of the 1114 Mesoarchean Fiskenæsset Complex at Majorqap qâva, SW Greenland: Evidence for two 1115 different magma compositions. Chemical Geology 314-317, 66-82.

1116 Hynes, A., 2014. How feasible was subduction in the Archean? Canadian Journal of Earth 1117 Sciences 51, 286-296.

1118 Irvine, T.N., 1974. Petrology of the Duke Island Ultramafic Complex Southeastern Alaska. The 1119 Geological Society of America Memoir, Inc. 138, 240 pp.

1120 Jenner, F.E., Bennett, V.C., Nutman, A.P., Friend, C.R.L., Norman, M.D., Yaxley, G., 2009. 1121 Evidence for subduction at $3.8 \mathrm{Ga}$ : geochemistry of arc-like metabasalts from the southern 1122 edge of the Isua Supracrustal Belt. Chemical Geology 261, 83-98.

1123 Johnson, T.E., Brown, M., Kaus, B.J.P., Van Tongeren, J.A., 2014. Delamination and recycling 1124 of Archaean crust caused by gravitational instabilities. Nature Geosciences 7, 47-52.

1125 Kalsbeek, F., Myers, J.S., 1973. The geology of the Fiskenæsset region. Rapport Grønlands 1126 Geologiske Undersøgelse 51, 5-22.

1127 Kalsbeek, F., Pidgeon, R.T., 1980. The geological significance of Rb-Sr whole-rock isochrons of 1128 polymetamorphic Archean gneisses, Fiskenæsset area, southern West Greenland. Earth and 1129 Planetary Science Letters 50, 225-237.

1130 Kamber, B.S., 2015. The evolving nature of terrestrial crust from the Hadean, through the 1131 Archaean, into the Proterozoic. Precambrian Research 258, 48-82. 
1132 Kamber, S.B., Moorbath, S., 1998. Initial Pb of the Amîtsoq gneisses revisited: implications for 1133 the timing of early Archean crustal evolution in West Greenland. Chemical Geology 150, 19113441

1135 Kamber, B.S., Moorbath, S., Whitehouse, M.J., 1998. Extreme Nd-isotope heterogeneity in the 1136 early Archean- fact or fiction? Case histories from northern Canada and West Greenland1137 Reply. Chemical Geology 148, 219-224.

1138 Kellogg, L.H., Hager, B.H., van der Hilst, D.D., 1999. Compositional stratification the deep 1139 mantle. Science 283, 1881-1884.

1140 Kerrich, R., Wyman, D., 1990. Geodynamic setting of mesothermal gold deposits: An 1141 association with accretionary tectonic regimes. Geology 18, 882-885.

1142 Keto, L., Kurki, J., 1967. Report on the exploration activity at Isua 1967. Kryolitselkabet 1143 Øresund A/S prospecting: Rapport 20024. Geological Survey of Denmark and Greenland.

1144 Keulen, N., Næraa, T., Kokfelt, T.F., Schumacher, J.C., Scherstén, A., 2010. Zircon record of the 1145 igneous and metamorphic history of the Fiskenæsset anorthosite complex in southern West 1146 Greenland. Geological Survey of Denmark and Greenland Bulletin 20, 67-70.

1147 Keulen, N., Schumacher, J.C., Næraa, T., Kokfelt, T.F., Scherstén, A., Szilas, K., van Hinsberg, 1148 V.J., Schlatter, D.M., Windley, B.F., 2014. Meso- and Neo-archaean geological history of the 1149 Bjørnesund and Ravns Storø Supracrustal Belts, southern West Greenland: Settings for gold 1150 enrichment and corundum formation. Precambrian Research 254, 36-58

1151 Kisters, A.F.M., van Hinsberg, V.J., Szilas, K., 2012. Geology of an Archaean accretionary 1152 complex - the structural record of burial and return flow in the Tartoq Group of South West 1153 Greenland. Precambrian Research 220-221, 107-122. 
1154

1155

1156

1157

1158

1159

1160

1161

1162

1163

1164

1165

1166

1167

1168

1169

1170

1171

1172

1173

1174

1175

1176

Kolb, J., Kokfelt, T.F., Dziggel, A., 2012. Geodynamic setting and deformation history of an Archaean terrane at mid-crustal level: The Tasiusarsuaq terrane of southern West Greenland. Precambrian Research 212-213, 34-56.

Kolb, J., Dziggel, A., Schlatter, D.M., 2013. Gold occurrences of the Archean North Atlantic craton, southwestern Greenland: A comprehensive genetic model. Ore Geology Reviews 54, 24-58.

Komiya, T., Maruyama, S., Masuda, T., Nohda, S., Hayashi, M., Okamoto, K., 1999. Plate Tectonic at 3.8-3.7 Ga: Field evidence from the Isua accretionary Complex, Southern West Greenland. Journal of Geology 107, 515-554.

Knudsen, C., van Gool, J.A.M., Østergaard, C., Hollis, J.A., Rink-Jørgensen, M., Persson, M., Szilas, K., 2007. Gold-hosting supracrustal rocks on Storø, southern West Greenland: lithologies and geological environment. Geological Survey of Denmark and Greenland Bulletin 13, 41-44.

Kurth, M., Sassen, A., Suhr, G., Mezger, K., 1998. Precise ages and isotopic constraints for the Lewis Hills (Bay of Islands Ophiolite): Preservation of an arc-spreading ridge intersection. Geology 26, 1127-1130.

Kusky, T.M., 2004. Epilogue: What if anything have we learned about Precambrian ophiolites and early Earth processes? In: Kusky T.M. (Ed.), Precambrian Ophiolites and Related Rocks, Developments in Precambrian Geology, Vol. 13 (K.C. Condie, Series Editor), Elsevier B.V., Amsterdam, pp.727-637.

Kusky, T.M., Li, X., Wang, Z., Fu, J., Ze, L., Zhu, P., 2014. Are Wilson Cycles preserved in Archean cratons? A comparison of the North China and Slave cratons. Canadian Journal of Earth Sciences 51, 297-311. 
1177 Kusky, T., Polat, A., 1999. Growth of granite-greenstone terranes at convergent margins, and 1178 stabilization of Archean cratons. Tectonophysics 305, 43-73.

1179 Lesher, C.M., Arndt, N.T., 1995. REE and Nd isotope geochemistry, petrogenesis and volcanic 1180 evolution of contaminated komatiites at Kambalda, Western Australia. Lithos 34, 127-157.

1181 Liu, F., Liou, J.G., Xu, Z., 2005. U-Pb SHRIMP ages recorded in the coesite-bearing zircon 1182 domains of paragneisses in the southwestern Sulu terrane, eastern China: new interpretation. 1183 American Mineralogist 90, 790-800.

1184 Liou, J.G., Zhang, R.Y., 1996. Occurrences of intergranular coesite in UHP rocks from the Sulu 1185 region, eastern China: implications for lack of fluid during exhumation. American $1186 \quad$ Mineralogist 81, 1217-1221.

1187 Lowry, D., Appel, P.W.U., Rollinson, H.R., 2003. Oxygen isotopes of an Early Archaean layered 1188 ultramafic body, southern West Greenland: implications for magma source and post-intrusion 1189 history. Precambrian Research 126, 273-288.

1190 Mann, P., Taira, A., 2004. Global tectonic significance of the Solomon Islands and Ontong Java 1191 convergent zone. Tectonophysics 389, 137-190.

1192 Martin, H., Moyen, J.-F., Guitreau, M., Blichert-Toft, J., Le Pennec, J.-L., 2014. Why Archaean 1193 TTG cannot be generated by MORB melting in subduction zones. Lithos 198-199, 1-13.

1194 McGregor, V.R., 1973. The early Precambrian gneisses of the Godthåb district, West Greenland. 1195 Philosophical Transactions of the Royal Society of London, A273, 343-358.

1196 McGregor, V.R., Friend, C.R.L., 1992. Late Archean prograde amphibolite to granulite-facies 1197 relations in the Fiskenæsset region, Southern West Greenland. Journal of Geology 100, 2071198219. 
1199 McGregor, V.R., Friend, C.R.L., Nutman, A.P., 1991. The late Archaean mobile belt through 1200 Godthåbsfjord, southern West Greenland: a continent-continent collision zone? Bulletin of 1201 the Geological Society of Denmark 39, 179-197.

1202 Meng, Q.R., Zhang, G.W., 2000. Geologic framework and tectonic evolution of the Qinling 1203 orogen, central China. Tectonophysics 323, 183-196.

1204 Moorbath, S., O’Nions, R.K., Pankhurst, R.J., 1973. Early Archean age for the Isua Iron 1205 formation, West Greenland. Nature 245, 138-139.

1206 Moorbath, S., Taylor, P.N., Goodwin, R., 1981. Origin of granitic magma by crustal 1207 remobilisation: $\mathrm{Rb}-\mathrm{Sr}$ and $\mathrm{Pb} / \mathrm{Pb}$ geochronology and isotope geochemistry of the late 1208 Archaean Qôrqut granite complex of southern West Greenland. Geochimica et Cosmochimica $1209 \quad$ Acta 45, 1051-1060.

1210 Moore, W.B., Webb, A.A.G., 2013. Heat-pipe Earth. Nature 501, 501-505.

1211 Myers, J.S., 1976. Granitoid sheets, thrusting, and Archean crustal thickening in West 1212 Greenland. Geology 4, 265-268.

1213 Myers, J.S., 1985. Stratigraphy and structure of the Fiskenæsset Complex, southern West 1214 Greenland. Grønlands Geologiske Undersøgelse Bulletin 150, 72 pp.

1215 Myers, J.S., 2001. Protoliths of the 3.7-3.8 Ga Isua greenstone belt, West Greenland. $1216 \quad$ Precambrian Research 105, 129-141.

1217 Næraa, T., Kemp, A.I.S., Scherstén, A., Rehnström, E.F., Rosing, M.T., Whitehouse, M.J., 2014. 1218 A lower crustal mafic source for the ca. 2550 Ma Qôrqut Granite Complex in southern West 1219 Greenland. Lithos 192-195, 291-304.

1220 Nagel, T.J., Hoffmann, J.E., Münker, C., 2012, Generation of Eoarchean tonalitic-trondhjemitic1221 granodioritics from thickened mafic arc crust. Geology 40, 375-378. 
1222 Nebel-Jacobsen, Y., Münker, C., Nebel, O., Gerdes, A., Mezger, K., Nelson, D.R., 2010.

1223 Reworking of Earth's first crust: constraints from Hf isotopes in Archean zircons from Mt.

$1224 \quad$ Narryer, Australia. Precambrian Research 182, 175-186.

1225 Nutman, A.P., 1986. The early Archean to Proterozoic history of the Isukasia area, southern 1226 West Greenland. Geological Survey of Greenland Bulletin 154, pp. 80.

1227 Nutman, A.P., Bennett, V.C., Friend, C.R.L., Horie, K., Hidaka, H., 2007a. 3.850 Ma tonalities 1228 in the Nuuk region, Greenland: geochemistry and their reworking within an Eoarchean gneiss 1229 Complex. Contributions to Mineralogy and Petrology 154, 385-408.

1230 Nutman, A.P., Bennett, V.C., Friend, C.R.L., 2015a. The emergence of the Eoarchaean proto1231 arc: evolution of a c. 3700 Ma convergent plate boundary at Isua, southern West Greenland. 1232 In: Roberts, N.M.W., Van Kranendonk, M., Parman, S., Shirey, S., Clift, P.D. (Eds.), 1233 Continent Formation Through Time. Geological Society, London, Special Publications 389, $1234 \quad 113-133$.

1235 Nutman, A.P., Bennett, V.C., Friend, C.R.L., Yi, K., Lee, S.R., 2015b. Mesoarchaean collision 1236 of Kapisilik terrane 3070 Ma juvenile arc rocks and >3600 Ma Isukasia terrane continental 1237 crust (Greenland). Precambrian Research 258, 146-160.

1238 Nutman, A.P., Bennett, V.C., Friend, C.R.L., Rosing, M.T., 1997. 3710 and 3790 Ma volcanic 1239 sequences in the Isua (Greenland) supracrustal belt; structural and Nd isotope implications. 1240 Chemical Geology 141, 271-287.

1241 Nutman, A.P., Bennett, V.C., Friend, C.R.L., Norman, M.D., 1999. Meta-igneous (non-gneissic) 1242 tonalites and quartz-diorites from an extensive ca. $3800 \mathrm{Ma}$ terrain south of the Isua 1243 supracrustal belt, southern West Greenland: constraints on early crust formation. $1244 \quad$ Contributions to Mineralogy and Petrology 137, 364-388. 
1245 Nutman, A.P., Christiansen, O., Friend, C.R.L., 2007b. 2635 Ma amphibolite facies gold 1246 mineralisation near a terrane boundary (suture?) on Storø, Nuuk region, southern West 1247 Greenland. Precambrian Research 159, 19-32.

1248 Nutman, A.P., Collerson, K.D., 1991. Very early Archean crustal-accretion complexes preserved 1249 in the North Atlantic craton. Geology 19, 791-794.

1250 Nutman, A.P., Friend, C.R.L., 2007. Adjacent terranes with ca. 2715 and 2650 Ma high-pressure 1251 metamorphic assemblages in the Nuuk region of the North Atlantic Craton, southern West 1252 Greenland: Complexities of Neoarchaean collisional orogeny. Precambrian Research 155, $1253 \quad 159-203$.

1254 Nutman, A.P., Friend, C.R.L., 2009. New 1:20,000 scale geological maps, synthesis and history 1255 of investigation of the Isua supracrustal belt and adjacent orthogneisses, southern West 1256 Greenland: A glimpse of Eoarchean crust formation and orogeny. Precambrian Research 172, $1257 \quad 189-211$.

1258 Nutman, A.P., Friend, C.R.L., Baadsgaard, H., McGregor, V.R., 1989. Evolution and assembly 1259 of Archean gneiss terranes in the Godthåbsfjord region, southern West Greenland: structural, 1260 metamorphic and isotopic evidence. Tectonics 8, 573-589.

1261 Nutman, A.P., Garde, A.A., 1989. Fluid control on emplacement of sialic magmas during 1262 Archaean crustal accretion. In: Bridgwater, D., (Ed.), Fluid Movements - Element Transport 1263 and the Composition of the Deep Crust. Kluwer, Dordrecht, pp. 235-243.

1264 Nutman, A.P., McGregor, V.R., Friend, C.R.L., Bennett, V.C., Kinny, P.D., 1996. The Itsaq 1265 Gneiss Complex of southern West Greenland; the world's most extensive record of early 1266 crustal evolution. Precambrian Research 78, 1-39. 
1267 Nutman, A.P., Friend, C.R.L., Paxton, S., 2009. Detrital zircon sedimentary provenance ages for 1268 the Eoarchean Isua supracrustal belt southern West Greenland: Juxtaposition of a ca. $3700 \mathrm{Ma}$ 1269 juvenile arc assemblage against an older complex with 3920-3800 Ma components. $1270 \quad$ Precambrian Research 172, 212-233.

1271 Nutman, A.P., Friend, C.R.L., Bennett, V.C., 2002. Evidence for 3650-3600 Ma assembly of the 1272 northern end of the Itsaq Gneiss Complex, Greenland: Implication for early Archean 1273 tectonics. Tectonics 10.1029/2000TC001203.

1274 Nutman, A.P., Bennett, V.C., Friend, C.R.L., McGregor, V.R., 2000. The early Archean Itsaq 1275 Gneissic Complex of southern West Greenland: the importance of field observations in 1276 interpreting age and isotopic constraints for early terrestrial evolution. Geochimica et 1277 Cosmochimica Acta 64, 3035-3060.

1278 Nutman, A.P., Bennett, V.C., Friend, C.R.L., Hidaka, H., Yi, K., Lee, S.R., Kamiichi, T., 2013. 1279 The Itsaq Gneiss Complex of Greenland: Episodic 3900 to 3660 Ma juvenile crust formation 1280 and recycling in the 3660-3600 Ma Isukasian orogeny. American Journal of Science 313, 1281 877-911.

1282 Nutman, A.P., Friend, C.R.L., Barker, S.L.L., McGregor, V.R., 2004. Inventory and assessment 1283 of Paleoarchean terrains and detrital zircons in southern West Greenland. Precambrian $1284 \quad$ Research 135, 281-314.

1285 Nutman, A.P., Kalsbeek, K., 1994. A minimum age of $2944 \pm 7$ Ma for the Târtoq Group, South1286 West Greenland. Bulletin Grønlands Geologiske Undersøgelse 161, 35-38.

1287 O’Neil, J., Francis, D., Carlson, R.W., 2011. Implications of the Nuvvuagittuq greenstone belt 1288 for the formation of Earth's early crust. Journal of Petrology 52, 985-1009. 
1289 Ordóñez-Calderón, J.C., Polat, A., Fryer, B., Appel, P.W.U., van Gool, J.A.M., Dilek, Y., 1290 Gagnon, J.E., 2009. Geochemistry and geodynamic origin of Mesoarchean oceanic crust in 1291 the Ujarassuit and Ivisaartoq greenstone belts, SW Greenland. Lithos 113, 133-157.

1292 Ordóñez-Calderón, J.C., Polat, A., Fryer, B.J., Gagnon, J.E., 2011. Field and geochemical 1293 characteristics of Mesoarchean to Neoarchean volcanic rocks in the Storø greenstone belt, SW 1294 Greenland: Evidence for accretion of intra-oceanic volcanic arcs. Precambrian Research 184, $1295 \quad 24-42$.

1296 Oreskes, N., 2003. Plate Tectonics - An Insider's History of the Modern Theory of the Earth. 1297 Westview Press, Colorado, 424 pp.

1298 Østergaard, C., van Gool, J.A.M., 2007. Assessment of gold mineralization on Storø, 1299 Godthåbsfjord, southern West Greenland. Danmarks Og Grønlands Geologiske Undersøgelse $1300 \quad$ Rapport 2007/78, 20 pp.

1301 Owens, B.E., Dymek, R.F., 1997. Comparative petrology of Archean anorthosites in amphibolite 1302 and granulite facies terranes, SW Greenland. Contributions to Mineralogy and Petrology 128, $1303 \quad 371-384$.

1304 Passchier, C.W., Myers, J.S., Kroner, A., 1990. Field Geology of High-Grade Gneiss Terrains, 1305 Springer-Verlag, Berlin, 159 pp.

1306 Percival, J.A., Sanborn-Barrie, M., Skulski, T., Stott, G.M., Helmstaedt, H., White, D.J., 2006. 1307 Tectonic evolution of the western Superior Province from NATMAP and Lithoprobe 1308 studies. Canadian Journal of Earth Sciences 43, 1085-1117.

1309 Percival, J.A., Skulski, T., Sanborn-Barrie, M., Stott, G.M., Leclair, A.D., Corkery, M.T., Boily, 1310 M., 2012. Geology and Tectonic Evolution of the Superior Province, Canada in: Percival, 
1313 Petersen, J.S., 1992. Nuuluk-Iterlak gold and massive-sulfide project, Taartoq Archaean 1314 greenstone belt, SW Greenland. (Field report, Nunaoil A/S, 164 pp).

1315 Pidgeon, R.T., Kalsbeek, F., 1978. Dating of igneous and metamorphic events in the Fiskenæsset 1316 region of southern West Greenland. Canadian Journal of Earth Sciences 15, 2021-2025.

1317 Polat, A., 2014. John Tuzo Wilson: a Canadian who revolutionized Earth Sciences. Canadian 1318 Journal of Earth Sciences 51, v-viii.

1319 Polat, A., 2012. Growth of Archean continental crust in oceanic island arcs. Geology 40, 383$1320 \quad 384$.

1321 Polat, A., Dziggel, A., 2011. Summary of field work in the Tartoq Group in 2010, pp. 148-158.

1322 Geological Survey of Denmark and Greenland, Ministry of Climate and Energy Report $1323 \quad 2011 / 114$.

1324 Polat, A., Frei, R., 2005. The origin of early Archean banded iron formations and of continental 1325 crust, Isua, southern West Greenland. Precambrian Research 138, 151-175.

1326 Polat, A., Frei, R., Fryer, B., Appel, P.W.U., 2009a. The origin of geochemical trends and 1327 Eoarchean (ca. $3700 \mathrm{Ma}$ ) zircons in Mesoarchean (ca. $3075 \mathrm{Ma}$ ) ocelli-hosting pillow basalts, 1328 Ivisaartoq greenstone belt, SW Greenland: evidence for crustal contamination versus crustal 1329 recycling. Chemical Geology 268, 248-271.

1330 Polat, A., Appel, P.W.U., Fryer, B., Windley, B., Frei, R., Samson, I.M., Huang, H., 2009 b. 1331 Trace element systematics of the Neoarchean Fiskenæsset anorthosite complex and associated 1332 meta-volcanic rocks, SW Greenland: Evidence for a magmatic arc origin. Precambrian $1333 \quad$ Research 175, 87-115. 
1334 Polat, A., Appel, P.W.U., Fryer, B., 2011a. An overview of the geochemistry of Eoarchean to 1335 Mesoarchean ultramafic to mafic volcanic rocks, SW Greenland: Implications for mantle 1336 depletion and petrogenetic processes at subduction zones in the early Earth. Gondwana $1337 \quad$ Research 20, 255-283.

1338 Polat, A., Appel, P.W.U., Frei, R., Pan, Y., Dilek, Y., Ordóñez-Calderón, J.C., Fryer, B., Hollis, 1339 J.A., Raith, J.G., 2007. Field and geochemical characteristics of the Mesoarchean ( 3075 Ma) 1340 Ivisaartoq greenstone belt, southern West Greenland: Evidence for seafloor hydrothermal 1341 alteration in a supra-subduction oceanic crust. Gondwana Research 11, 69-91.

1342 Polat, A., Frei, R., Appel, P.W.U., Dilek, Y., Fryer, B., Ordóñez-Calderón, J.C., Yang, Z., 2008. 1343 The origin and compositions of Mesoarchean oceanic crust: Evidence from the $3075 \mathrm{Ma}$ 1344 Ivisaartoq greenstone belt, SW Greenland. Lithos 100, 293-321.

1345 Polat, A., Fryer, B., Appel, P.W.U., Kalvig, P., Kerrich, R., Dilek, Y., Yang, Z., 2011 b. 1346 Geochemistry of anorthositic differentiated sills in the Archean ( 2970 Ma) Fiskenæsset 1347 Complex, SW Greenland: Implications for parental magma compositions, geodynamic 1348 setting, and secular heat flow in arcs. Lithos 123, 50-72.

1349 Polat, A., Fryer, B., Samson, I.M., Weisener, C., Appel, P.W.U., Frei, R., Windley, B.F., 2012. 1350 Geochemistry of ultramafic rocks and hornblendite veins in the Fiskenæsset layered 1351 anorthosite complex, SW Greenland: Evidence for hydrous upper mantle in the Archean. 1352 Precambrian Research 214-215, 124-153.

1353 Polat, A., Hofmann, A.W., 2003. Alteration and geochemical patterns in the 3.7-3.8 Ga Isua 1354 greenstone belt, West Greenland. Precambrian Research 126, 197-218. 
1355 1356

1357

1358

1359

1360

1361

1362

1363

1364

1365

1366

1367

1368

1369

1370

1371

1372

1373

1374

1375

1376

Polat, A., Hofmann, A.W., Rosing, M., 2002. Boninite-like volcanic rocks in the $3.7-3.8$ Ga Isua greenstone belt, West Greenland: Geochemical evidence for intra-oceanic subduction zone processes in the early Earth. Chemical Geology 184, 231-254.

Polat, A., Frei, R, Scherstén, A., Appel, P. W.U., 2010. New age (ca. 2970 Ma), mantle source composition and geodynamic constraints on the Archean Fiskenæsset anorthosite complex, SW Greenland. Chemical Geology 277, 1-20.

Polat, A., Longstaffe, F.J., 2014. A juvenile oceanic island arc origin for the Archean (ca. 2.97 Ga) Fiskenæsset Anorthosite Complex, southwestern Greenland: Evidence from oxygen isotopes. Earth and Planetary Science Letters 396, 252-266.

Polat, A., Kerrich, R., 2006. Reading the Geochemical Fingerprints of Archean Hot Subduction Volcanic Rocks: Evidence for Accretion and Crustal Recycling in a Mobile Tectonic Regime. AGU Geophysical Monograph Series 164, 189-213.

Polat, A., Kerrich, R., Windley, B.F., 2009c. Archean crustal growth processes in the southern Superior Province and southern West Greenland: geodynamic and magmatic constraints. In: Cawood, P., Kröner, A., (Eds.), Accretionary Orogens in Space and Time, Geological Society of London, Special Publication 318, 155-191.

Ratschbacher, L., Franz, L., Enkelmann, E., Jonckheere, R., Pörschke, A., Hacker, B.R., Dong, S.W., Zhang, Y.Q., 2006. The Sino-KoreaneYangtze suture, the Huwan detachment, and the Paleozoic-Tertiary exhumation of (ultra)high-pressure rocks along the Tongbai-XinxianDabie Mountains. In: Hacker, B.R., McClelland, W.C., Liou, J.G., (Eds.), Ultrahigh-pressure Metamorphism: Deep Continental Subduction. Geological Society of America Special Paper, vol. 403, pp. 45-75. 
1377 Riciputi, L.R., Valley, J.W., McGregor, V.R., 1990. Conditions of Archean granulite 1378 metamorphism in the Godthåb-Fiskenæsset region, southern West Greenland. Journal of 1379 Metamorphic Geology 8, 171-190.

1380 Robin, C.M.I., Bailey, R.C., 2009. Simultaneous generation of Archean crust and subcratonic 1381 roots by vertical tectonics. Geology $37,523-526$.

1382 Rollinson, H, Claire Reid, C., Windley, B.F., 2010. Chromitites from the Fiskenæsset 1383 anorthositic complex, West Greenland: clues to late Archaean mantle processes. In: Kusky, 1384 T.M., Zhai, M., Xiao, W. (Eds.), The Evolving Continents: Understanding Processes of 1385 Continental Growth. Geological Society of London, Special Publications, 338, 197-212.

1386 Rosing, M.T., Nutman, A.P., Løfqvist, L., 2001. A new fragment of the early earth crust: the 1387 Aasivik terrane of West Greenland. Precambrian Research 105, 115-128.

1388 Santosh, M., Shaji, E., Tsunogae, T., Ram Mohan, M., Satyanarayanan, M., Horie, K., 2013. 1389 Suprasubduction zone ophiolite from Agali hill: Petrology, zircon SHRIMP U-Pb 1390 geochronology, geochemistry and implications for Neoarchean plate tectonics in southern 1391 India. Precambrian Research 231, 301-324.

1392 Saleeby, J.A., 1992. Age and tectonic setting of the Duke Island ultramafic intrusion, southeast 1393 Alaska. Canadian Journal of Earth Sciences 29, 506-522.

1394 Savage, B., 2012. Seismic constraints on the water flux delivered to the deep Earth by 1395 subduction. Geology 40, 235-238.

1396 Sawyer, E.W., 2008. Atlas of migmatites. Canadian Mineralogical Association Special 1397 Publication 9, NRC Research Press, Ottawa, pp 371.

1398 Schaefer, B.F., Turner, S., Parkinson, I., Rogers, N., Hawkesworth, C., 2002. Evidence for 1399 recycled Archean oceanic mantle lithosphere in the Azores plume. Nature 420, 304-307. 
1400 Scherstén, A., Szilas, K., Creaser, R.A., van Gool, J.A.M., Næraa, T., Østergaard, C., 2012. Re-

1401 Os and U-Pb constraints on gold mineralisation events in the Meso- to Neoarchaean Stor $\varnothing$

1402 greenstone belt, Storø, southern West Greenland. Precambrian Research 200-203, 149-162.

1403 Schumacher, J.C., van Hinsberg, V.J., Keulen, N., 2011. Metamorphism in supracrustal and 1404 ultramafic rocks in southern West Greenland and South-West Greenland 64-61.5 ${ }^{\circ} \mathrm{N}$.

1405 Danmarks og Grønlands Geologiske Undersøgelse Rapport 2011/06, 29 pp.

1406 Şengör, A.M.C. 1990. Plate Tectonics and orogenic research after 25 years: A Tethyan 1407 perspective. Earth Science Reviews 27, 1-201.

1408 Şengör, A.M.C., Natal'in, B.A., Burtman, V.S., 1993. Evolution of the Altaid tectonic collage 1409 and Phanerozoic crustal growth in Eurasia. Nature 364, 299-307.

1410 Şengör, A.M.C., Natal'in, B.A., 1996. Turkic-type orogeny and its rôle in the making of the 1411 continental crust. Annual Reviews of Earth Planetary Sciences 24, 263-337.

1412 Şengör, A.M.C., Natal'in, B. A., 2004. Phanerozoic analogues of Archaean oceanic basement 1413 fragments: Altaid ophiolites and ophirags. In: Kusky T.M. (Ed.), Precambrian Ophiolites and 1414 Related Rocks, Developments in Precambrian Geology, Vol. 13 (K.C. Condie, Series Editor), 1415 Elsevier B.V., Amsterdam, pp. 675-726.

1416 Șengör, A.M.C., Natal'in, B.A., Sunal, G., van der Voo, R., 2014. A new look at the Altaids: A 1417 superorogenic complex in Northern and Central Asia as a factory of continental crust. Part I: 1418 Geological data compilation (exclusive of palaeomagnetic observations). Austrian Journal of 1419 Earth Sciences 107, 169-232.

1420 Sleep, N.H., 1992. Archean plate tectonics: what can be learned from continental geology? 1421 Canadian Journal of Earth Sciences 29, 2066-2071. 
1422 Sobolev, A.V., Hofmann, A.W., Nikosian, I.K., 2000. Recycled oceanic crust observed in 'ghost 1423 plagioclase' within the source of Mauna Loa lavas. Nature 404, 986-990.

1424 Souders, A.K., Sylvester, P.J., Myers, J.S., 2013. Mantle and crustal sources of Archean 1425 anorthosite: a combined in situ isotopic study of $\mathrm{Pb}-\mathrm{Pb}$ in plagioclase and $\mathrm{Lu}-\mathrm{Hf}$ in zircon. 1426 Contributions to Mineralogy and Petrology 165, 1-24.

1427 Steenfelt, A., Garde, A.A., Moyen, J.-F., 2005. Mantle wedge involvement in the petrogenesis of 1428 Archaean grey gneisses in West Greenland. Lithos 79, 207-228.

1429 Stern, R.J., 2005. Evidence from ophiolites, blueschists, and ultrahigh-pressure metamorphic 1430 terranes that the modern episode of subduction tectonics began in Neoproterozoic time. 1431 Geology 33, 557-560.

1432 Stott, G. M., 1997. The Superior Province, Canada. In: de Wit, Ashwal, L.D., (Eds.), Tectonic 1433 Evolution of Greenstone Belts. Oxford Monographs on Geology and Geophysics 35, 1434 Clarendon Press, Oxford, pp. 480-507.

1435 Szilas, K., Garde, A.A., 2013. Mesoarchaean aluminous rocks at Storø, southern West 1436 Greenland: New age data and evidence of premetamorphic seafloor weathering of basalts. 1437 Chemical Geology 354, 124-138.

1438 Szilas, K., van Hinsberg, J., Creaser, R., Kisters, A.F.M., 2014. The geochemical composition of 1439 serpentinites in the Mesoarchaean Tartoq Group, SW Greenland: Harzburgitic cumulates or 1440 melt modified mantle? Lithos 198-199, 103-116.

1441 Szilas, K., Hoffmann, J.E., Scherstén, A., Rosing, M.T., Windley, B.F., Kokfelt, T.F., Keulen, 1442 N., van Hinsberg, V.J., Næraa, T., Frei, R., Carsten Münker, C., 2012a. Complex calc1443 alkaline volcanism recorded in Mesoarchaean supracrustal belts north of Frederikshåb Isblink, 
southern West Greenland: Implications for subduction zone processes in the early Earth.

1445 Precambrian Research 208-211, 90- 123

1446 Szilas, K., Næraa, T., Scherstén, A., Stendal, H., Frei, R., van Hinsberg, V. J., Kokfelt, T.F.,

1447 Rosing, M. T. 2012b. Origin of Mesoarchaean arc-related rocks with boninite/komatiite

1448 affinities from southern West Greenland. Lithos 144, 24-39.

1449 Szilas, K., Van Hinsberg, V.J., Kisters, A.F.M., Hoffmann, J.E., Windley, B.F., Kokfelt, T.F.,

1450 Scherstén, A., Frei, R., Rosing, M.T., Münker, C., 2013a. Remnants of arc-related

1451 Mesoarchean oceanic crust in the Tartoq Group of SW Greenland. Gondwana Research 23,

$1452 \quad 436-451$.

1453 Szilas, K., Hoffmann, J.E., Scherstén, A., Kokfelt, T.F., Münker, C., 2013b. Archean andesite

1454 petrogenesis: Insights from the Grædefjord Supracrustal Belt, southern West Greenland.

1455 Precambrian Research 236, 1-15.

1456 Szilas, K., van Gool, J. A., Scherstén, A., Frei, R., 2014. The Neoarchaean Storø Supracrustal

1457 Belt, Nuuk region, southern West Greenland: An arc-related basin with continent-derived

1458 sedimentation. Precambrian Research 247, 208-222.

1459 Tappe, S., Smart, K.A., Pearson, D.G., Steenfelt, A., Simonetti, A., 2011. Craton formation in 1460 Late Archean subduction zones revealed by first Greenland eclogites. Geology 39, 1103$1461 \quad 1106$.

1462 Thébaud, N., Rey, P.F., 2013. Archean gravity-driven tectonics on hot and flooded continents:

1463 Controls on long-lived mineralised hydrothermal systems away from continental margins. 1464 Precambrian Research 229, 93-104.

1465 Turner, S., Rushmer, T., Reagan, M., Moyen, J.-F., 2014. Heading down early on? Start of 1466 subduction on Earth. Geology 42, 139-142. 
1467

1468

1469

1470

1471

1472

1473

1474

1475

1476

1477

1478

1479

1480

1481

1482

1483

1484

1485

1486

1487

1488

1489

van Gool, J.A.M., Scherstén, A., Østergaard, C., Næraa, T., 2007. Geological setting of the Storø gold prospect, Godthåbsfjord region, southern West Greenland. Danmarks Og Grønlands Geologiske Undersøgelse Rapport 2007/83, 158 pp.

Wager, L. R., Brown, G. M., 1968. Layered Igneous Rocks. Edinburgh, Oliver and Boyd, Ltd.

Wang, L., Kusky, T.M., Li, S., 2010. Structural geometry of an exhumed UHP terrane in the eastern Sulu Orogen, China: Implications for continental collisional processes. Journal of Structural Geology 32, 423-444.

Wang, L. Kusky, T.M., Polat, A., Wang, S., Jiang, X., Zong, K., Wang, J., Deng, H., Fu, J., 2014. Partial melting of deeply subducted eclogite from the Sulu orogen in China. Nature Communications, 5:5604 | DOI: 10.1038/ncomms6604.

Wang, J.P., Kusky, T.M., Polat, A., Wang, L. Deng, H., Wang, S., 2013. A late Archean tectonic mélange in the Central Orogenic Belt, North China Craton. Tectonophysics 608, 929-946.

Wedepohl, K.H., Heinrichs, H., Bridgwater, D., 1991. Chemical characteristics and genesis of the quartzo-feldspathic rocks in the Archean crust of Greenland. Contributions to Mineralogy and Petrology 107, 163-179.

Weaver, B.L., Tarney, J., Windley, B., 1981. Geochemistry and petrogenesis of the Fiskenæsset anorthosites complex, southern West Greenland: nature and parent magma. Geochimica et Cosmochimica Acta 45, 711-725.

Weaver, B.L., Tarney, J., Windley, B., Leake, B.E., 1982. Geochemistry and petrogenesis of Archean metavolcanic amphibolites from Fiskenæsset, S.W. Greenland. Geochimica et Cosmochimica Acta 46, 2203-2215.

Wells, P.R.A., 1979. Chemical and thermal evolution of Archaean sialic crust, southern West Greenland. Journal of Petrology 20, 187-226. 
1490 Wells, P.R.A., 1981. Accretion of continental crust: thermal and geochemical consequences.

1491 Philosophical Transactions of the Royal Society (London) A301, 347-357.

1492 Windley, B.F., 1968. New Field relations from the early Precambrian of West Greenland.

1493 Grønlands Rapport Grønlands Geologiske Undersøgelse15, 27-31.

1494 Windley, B.F., 1993. Uniformitarianism today: plate tectonics is the key to the past. Journal of

1495 Geological Society, London, 150, 7-19.

1496 Windley, B.F, Garde, A.A., 2009. Arc-generated blocks with crustal sections in the North 1497 Atlantic craton of West Greenland: new mechanism of crustal growth in the Archean with 1498 modern analogues. Earth Science Reviews 93, 1-30.

1499 Windley, B.F., Smith, J.V., 1974. The Fiskenæsset Complex, West Greenland, part 2. General 1500 Mineral Chemistry from Qeqertarssuatsiaq. Grønlands Geologiske Undersøgelse Bulletin 108, $150154 \mathrm{pp}$.

1502 Windley, B.F., Smith, J.V., 1976. Archaean high-grade complexes and modern continental 1503 margins. Nature 260, 671-675.

1504 Windley, B.F., Bishop, F.C., Smith, J.V., 1981. Metamorphosed layered igneous complexes in 1505 Archean granulite-gneiss belts. Annual Reviews Earth and Planetary Sciences 9, 175-198.

1506 Yoshida, D., Hirajima, T., Ishiwatari, A., 2004. Pressure-temperature path recorded in the 1507 Yangkou garnet-peridotite, in Su-Lu UHP metamorphic belt, eastern China. Journal of 1508 Petrology 45, 1125-1145. 
1514 Fig. 1. Simplified geological map of the Archean craton of West Greenland, showing the 1515 locations of the Isua, Ivisaartoq-Ujarassuit, Qussuk, Bjørneøen, Storø, Grædefjord, Ravns 1516 Storø, Bjørnesund, Akuliaq Peninsula, and Tartoq supracrustal belts, the Fiskenæsset 1517 anorthositic complex, and Maniitsoq structure (modified after Escher and Pulvertaft, 1995).

1518 Fig. 2. Simplified geological map of the Fiskefjord and Napassoq regions, displaying a variety of 1519 fold interference patterns (modified from Geological map of sheet 2 Fredrikshåb Isblink1520 Søndre - Strømfjord, Geological Survey of Greenland). Mesoarchean homogenized gneisses 1521 occur within the Maniitsoq impact structure (see Garde et al., 2014).

1522 Fig. 3. Simplified geological map of the Godthåbsfjord and Ameralik regions, displaying a 1523 variety of fold interference patterns (modified from Geological map of sheet 2 Fredrikshåb 1524 Isblink-Søndre - Strømfjord, Geological Survey of Greenland).

1525 Fig. 4. Field photographs of structures at contacts between the supracrustal belts and the 1526 bordering TTG gneisses, and at contacts between the Fiskenæsset anorthositic complex and 1527 the bordering TTG gneisses in the Archean craton of West Greenland, indicating that the 1528 contacts are tectonic and characterized by mylonitic shear zones. Photographs (a-c) are from 1529 contact between the Akuliaq supracrustal belt and the bordering TTG gneisses; photograph 1530 (d) is from contact between the Ivisaartoq-Ujarassuit supracrustal belt and the bordering TTG 1531 gneisses; and photographs (e) and (f) are from contact between the Fiskenæsset anorthositic 1532 complex and the bordering TTG gneisses. Photograph (d) is from Polat et al. (2011a).

1533 Fig. 5. Field photographs of the major lithologies in the Eoarchean Isua supracrustal belt, 1534 consistent with an intra-oceanic lithological assemblage. Photograph (a) is from Polat et al. 

(2009c), photograph (b) is from Polat and Frei (2005), and photographs (c), (d), (e) and (f) are from Hoffmann et al. (2010).

1537 Fig. 6. Field photographs of a shear zone (a), overturned asymmetric Z- and S-folds (b), and a 1538 thrust fault (c) in the Eoarchean Isua supracrustal belt.

1539 Fig. 7. Field photographs of the major rock types in the Mesoarchean Ivisaartoq-Ujarassuit 1540 supracrustal belt, consistent with an intra-oceanic lithological assemblage. Photograph (a) is 1541 from Polat et al. (2007), photographs (b), (c) and (d) are from Polat et al. (2008), and 1542 photograph (e) is from Polat et al. (2011a).

1543 Fig. 8. Field photographs of the major rock types in the Neoarchean to Mesoarchean Storø 1544 supracrustal belt in the Godthåbsfjord region. Photographs (b) and (f) are from (Ordóñez$1545 \quad$ Calderón et al. (2011).

1546 Fig. 9. Field photographs of the major lithologies in the Mesoarchean Fiskenæsset (a-c), Ravns 1547 Storø (d and e) and Bjørnesund (f) supracrustal belt. Photograph (a) is from Polat et al. $1548 \quad(2009 b)$

1549 Fig. 10. Field photographs of the major rock types and structures in the Mesoarchean Tartoq 1550 1551 in the belt.

1552 Fig. 11. (a-b) Intrusion of a tonalite sheet along a thrust fault zone between two layers of 1553 anorthosite-leucogabbro at Sinarssuk in the Fiskenæsset Complex. (c) A simplified cross1554 section of the Fiskenæsset region through Majorqap qâva, relating the northern 1555 (Qeqertarssuatsiaq - Majorqap qâva - Sinarssuk) and southern (Kangârssuk - Qasse 1556 Bjørnesund) belts (see Fig. 1); $F_{1}$ and $F_{2}$ represent the folds formed during first and second 1557 folding episodes (Modified from Myers, 1985). 
1558 Fig. 12. Field photographs of the major rock types in the Mesoarchean Fiskenæsset anorthosite 1559 complex. Photographs (a), (e) and (f) are from Polat et al. (2009b), photograph (b) is from 1560 Huang et al. (2012), photograph (c) from Polat et al. (2010), and photograph (d) is from Polat 1561 et al. (2011b).

1562 Fig. 13. Field photographs from a shear zone between the Akuliaq supracrustal belt and the 1563 bordering TTG gneisses in the Akuliaq Peninsula of the Paamiut region. The patterns of these 1564 outcrop scale structures are similar to those developed on regional scales as shown in Figs. 2 1565 and 3.

1566 Fig. 14. Field photographs from the Fiskenæsset (a, b, c, e and f) and Ivisaartoq-Ujarassuit (d) 1567 regions showing the deformation and partial melting of amphibolites, and formation of TTG 1568 and granitic rocks.

1569 Fig. 15. Field photographs from the Fiskenæsset region showing the deformation and partial 1570 melting of amphibolites, and formation of TTG and granitic rocks.

1571 Fig. 16. A simple geodynamic model suggesting that some of the supracrustal belts (e.g., Isua, 1572 Ivisaartoq-Ujarassuit, Storø and Tartoq) in the Archean craton of West Greenland formed as 1573 accretionary complexes and oceanic island arc-forearcs (e.g., Fiskenæsset, Bjørnesund, 1574 Qussuk).

1575 Fig. 17. A simple geodynamic model suggesting that TTGs in the Archean craton of West 1576 Greenland were generated through partial melting of amphibolites in thickened arcs, and 1577 partial melting of mantle wedge and subducted oceanic crust.

1578 Fig. 18. Geological map of the Sulu ultrahigh-pressure (UHP) metamorphic belt (after Yoshida 1579 et al., 2004). Inset shows location of the Sulu Belt at the eastern end of the Qinling-Dabie 1580 orogen. 
1581 Fig. 19. Structural map of the General's Hill outcrop in the Sulu orogenic belt, Yangkou Bay, 1582 eastern China (modified after Wang et al., 2014).

1583 Fig. 20. Field photographs from the General's Hill outcrop, showing the deformation and partial 1584 melting of eclogites and retrogressed eclogites (amphibolites), forming an eclogitic migmatite 1585 with the felsic rocks contributing to the formation of continental crust. Black and red colors 1586 represent the mafic rocks (eclogites and amphibolites) and light color shows the felsic 1587 (leucosome) rocks. 


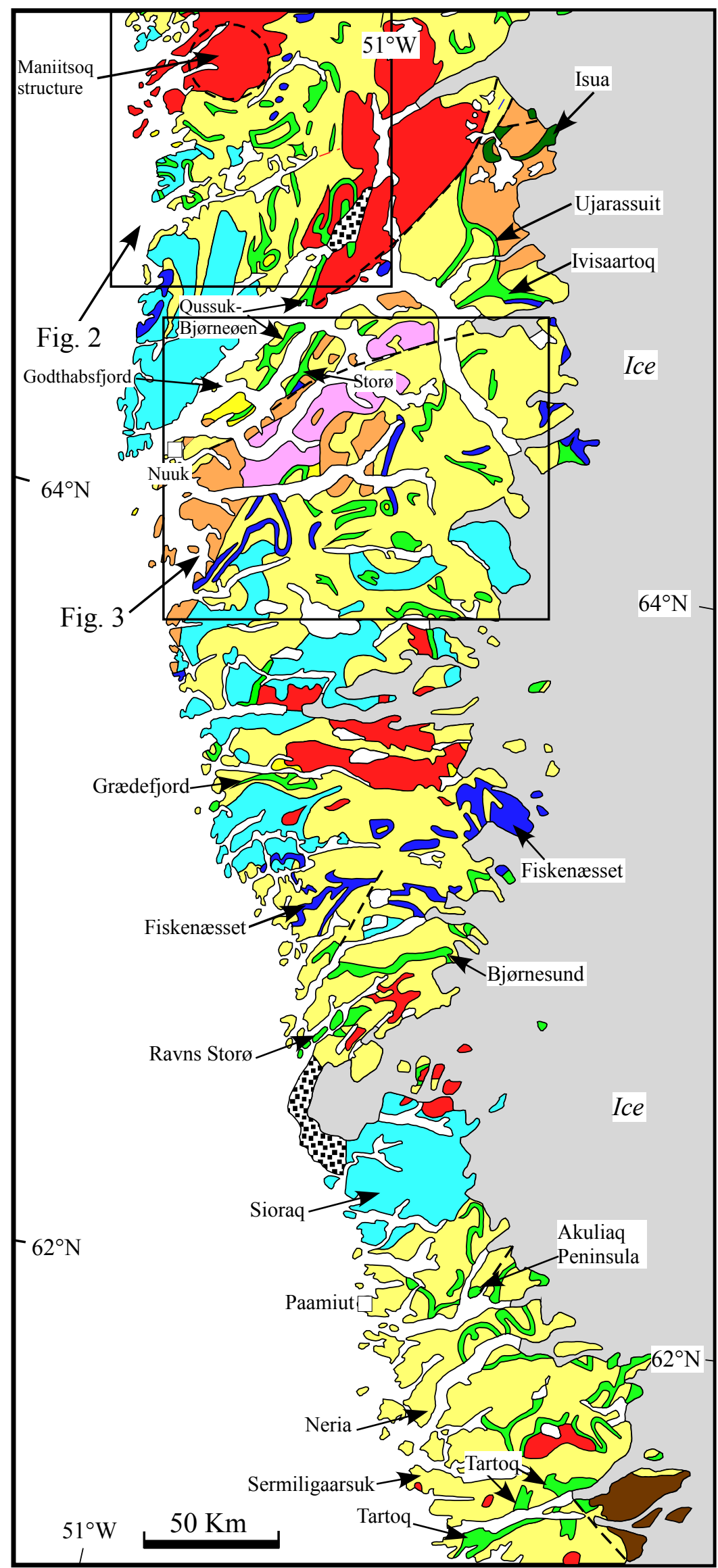

Legend

Puaternary deposits

Proterozoic supracrustal rocks

Neoarchean granites

(Qôrqut granite)

Mesoarchean to Neoarchean granitic gneisses

Mesoarchean granulite

facies gneisses

Mesoarchean gneisses

Mesoarchean layered

anorthosite complexes

Mesoarchean supracrustal rocks

Eoarchean gneisses

Eoarchean supracrustal rocks

' Major fault zone 


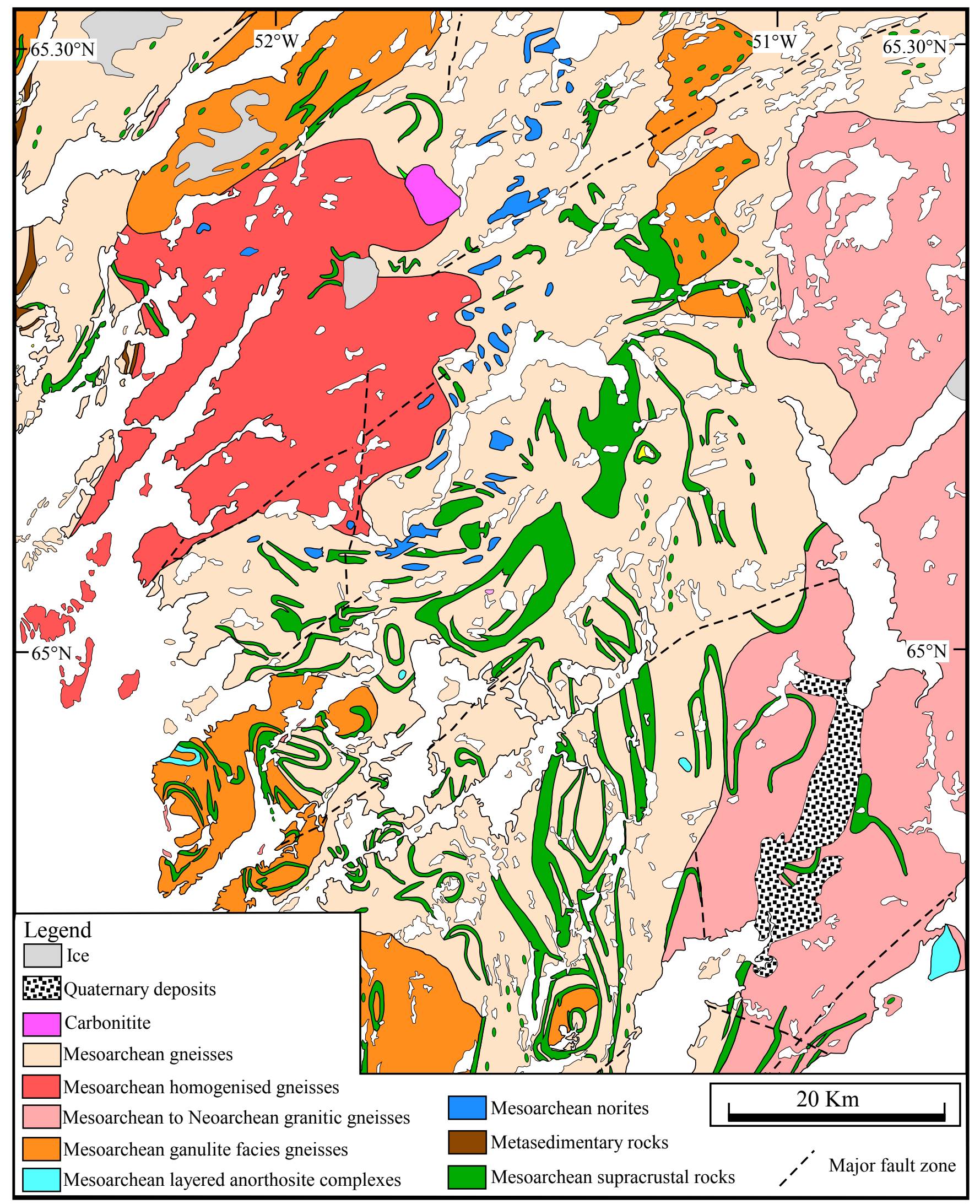




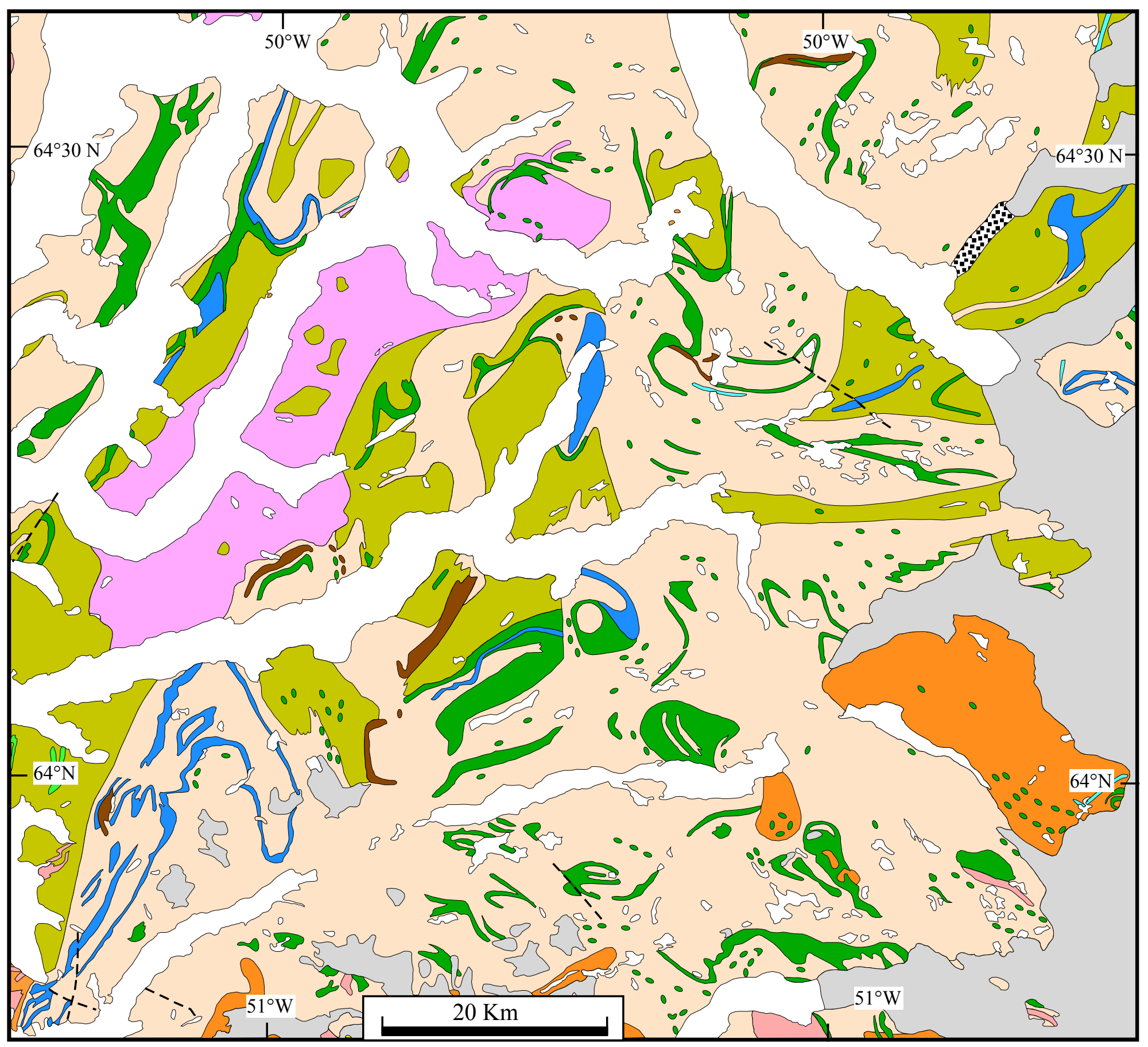

Legend

Ice

Quaternary deposits

Neoarchean granites (Qôrqut granite)

Mesoarchean to Neoarchean granitic gneisses

Mesoarchean ganulite facies gneisses

Mesoarchean gneisses
Mesoarchean layered anorthosite complexes

Metasedimentary rocks

Mesoarchean supracrustal rocks

Eoarchean gneisses

Eoarchean supracrustal rocks

,$\quad$ Major fault zone 

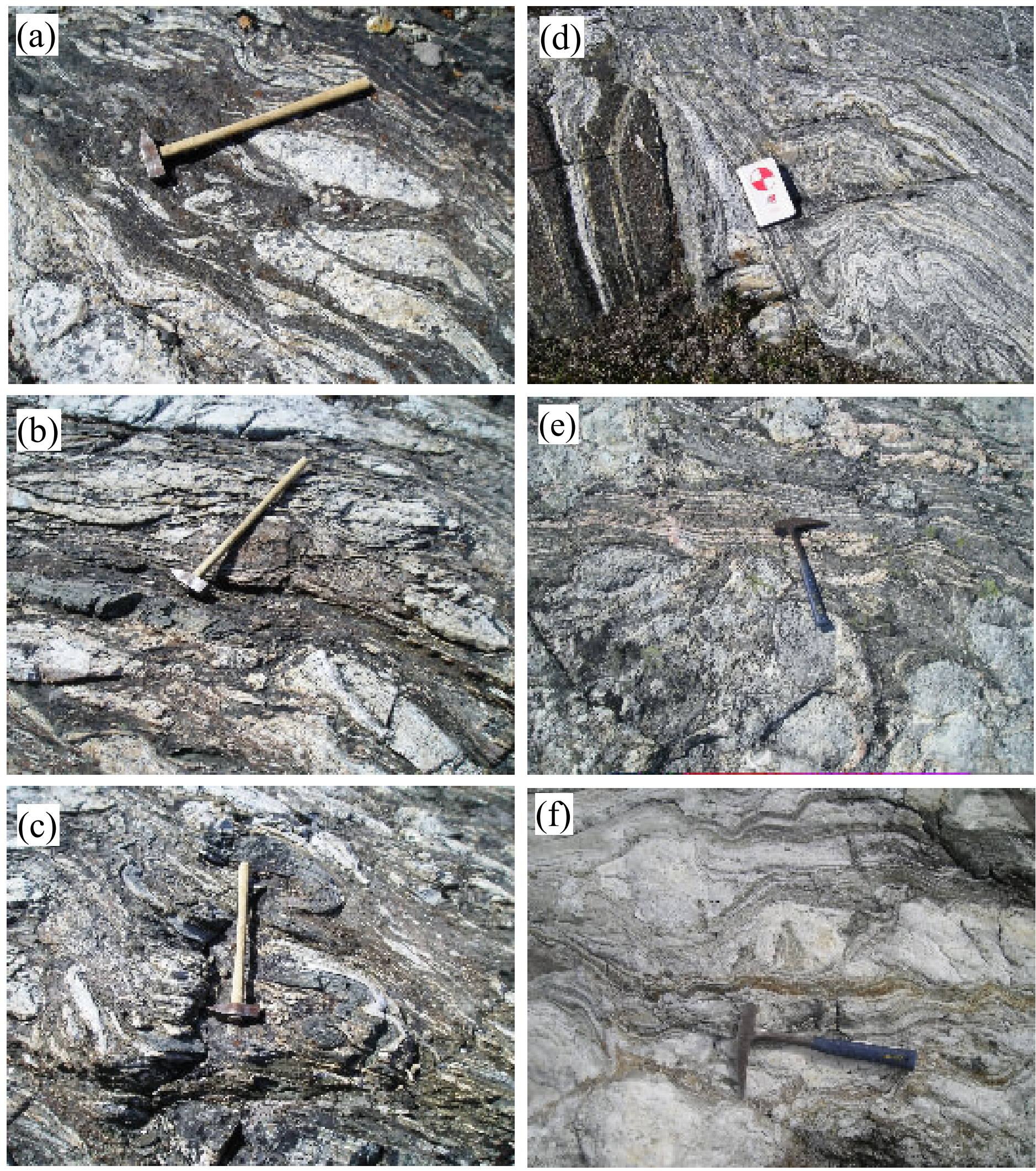

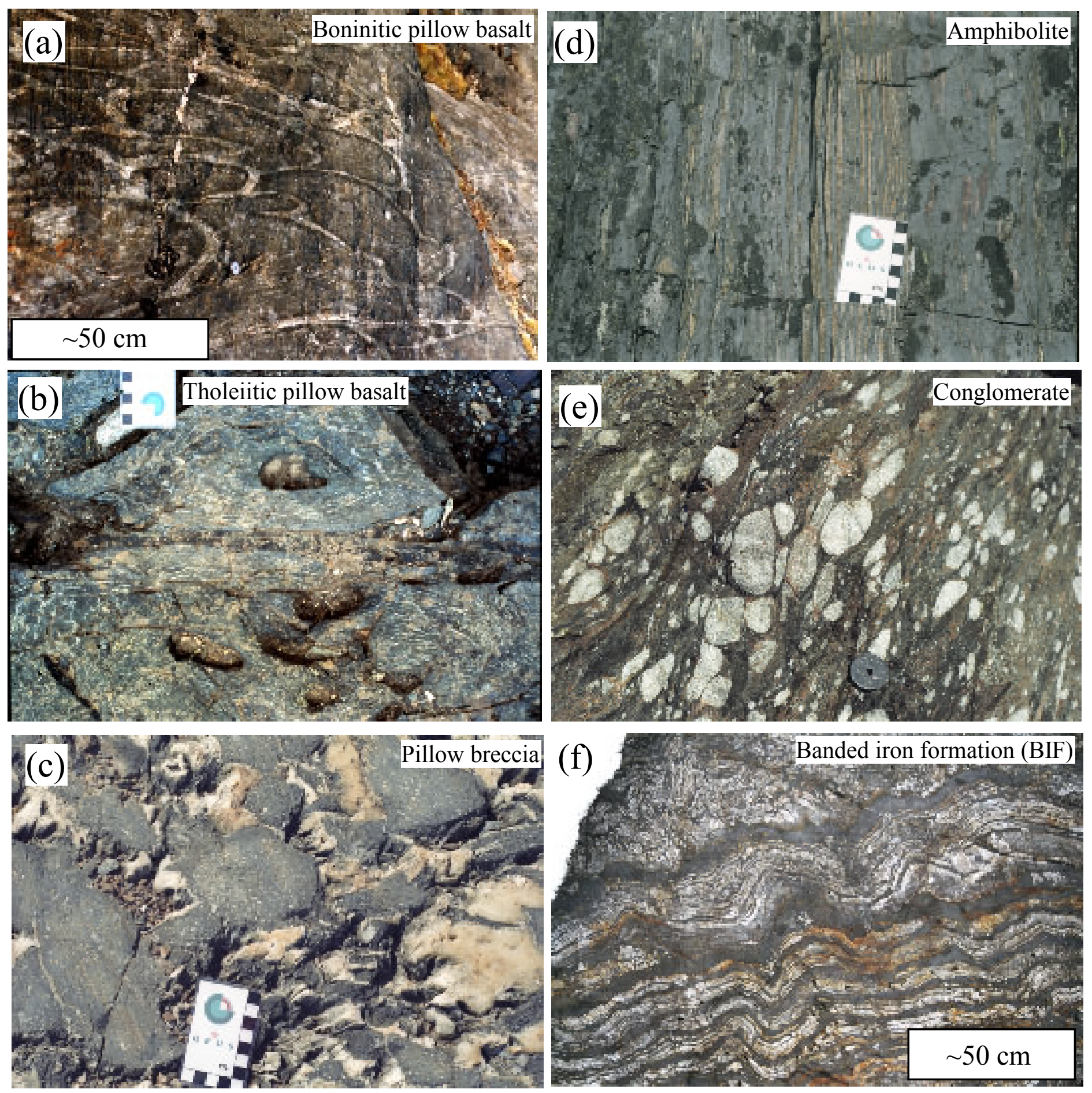

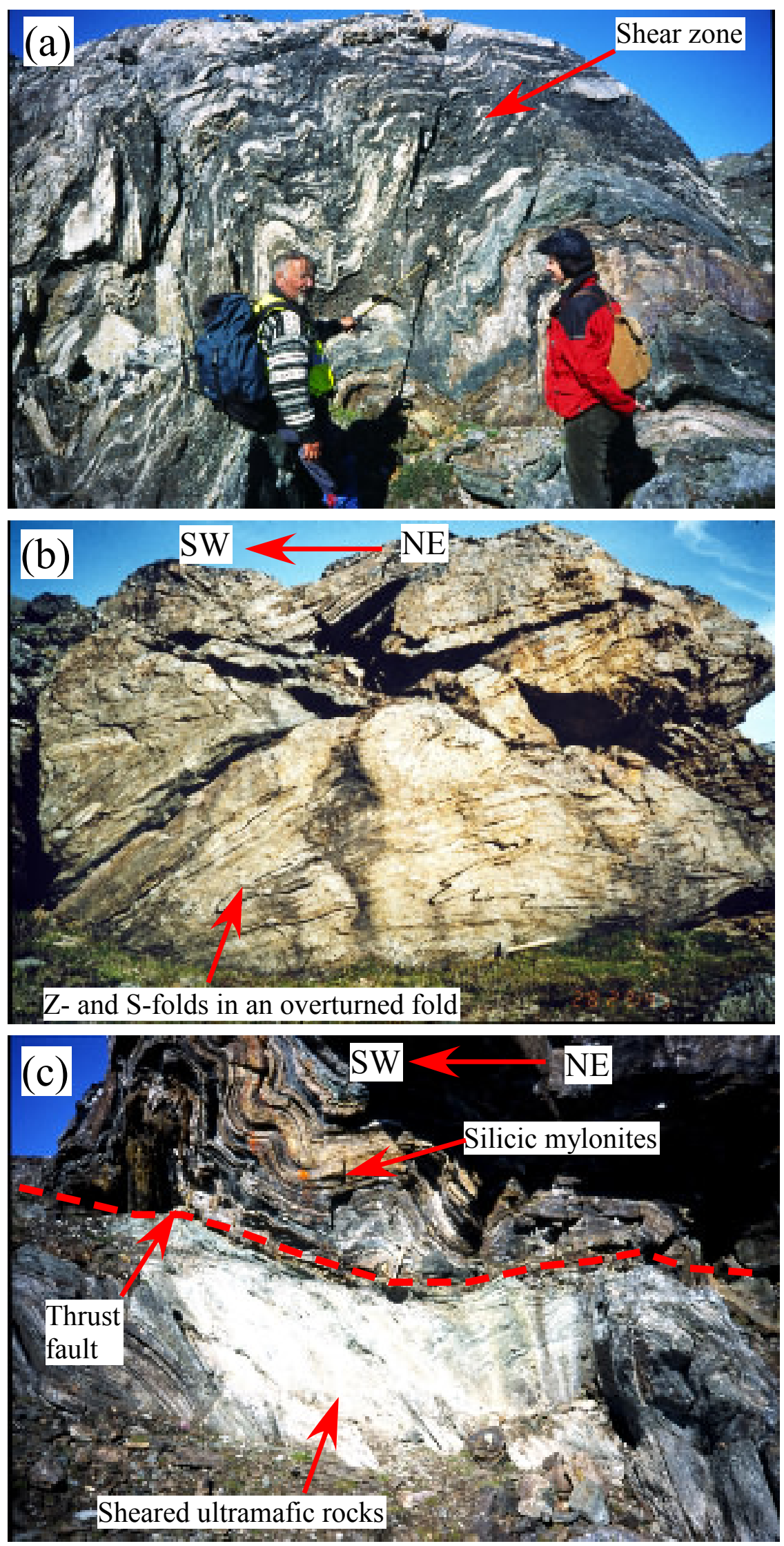

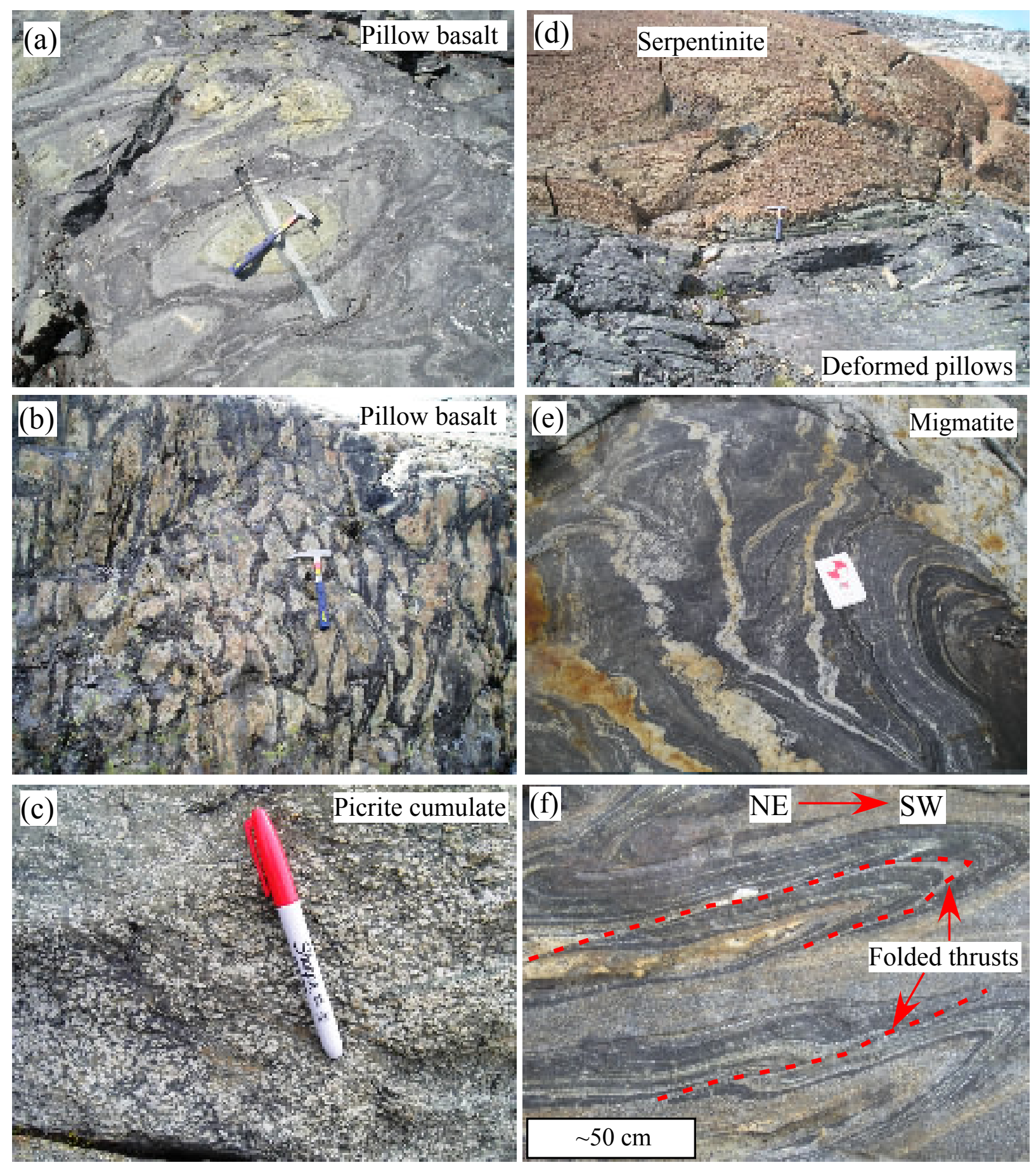

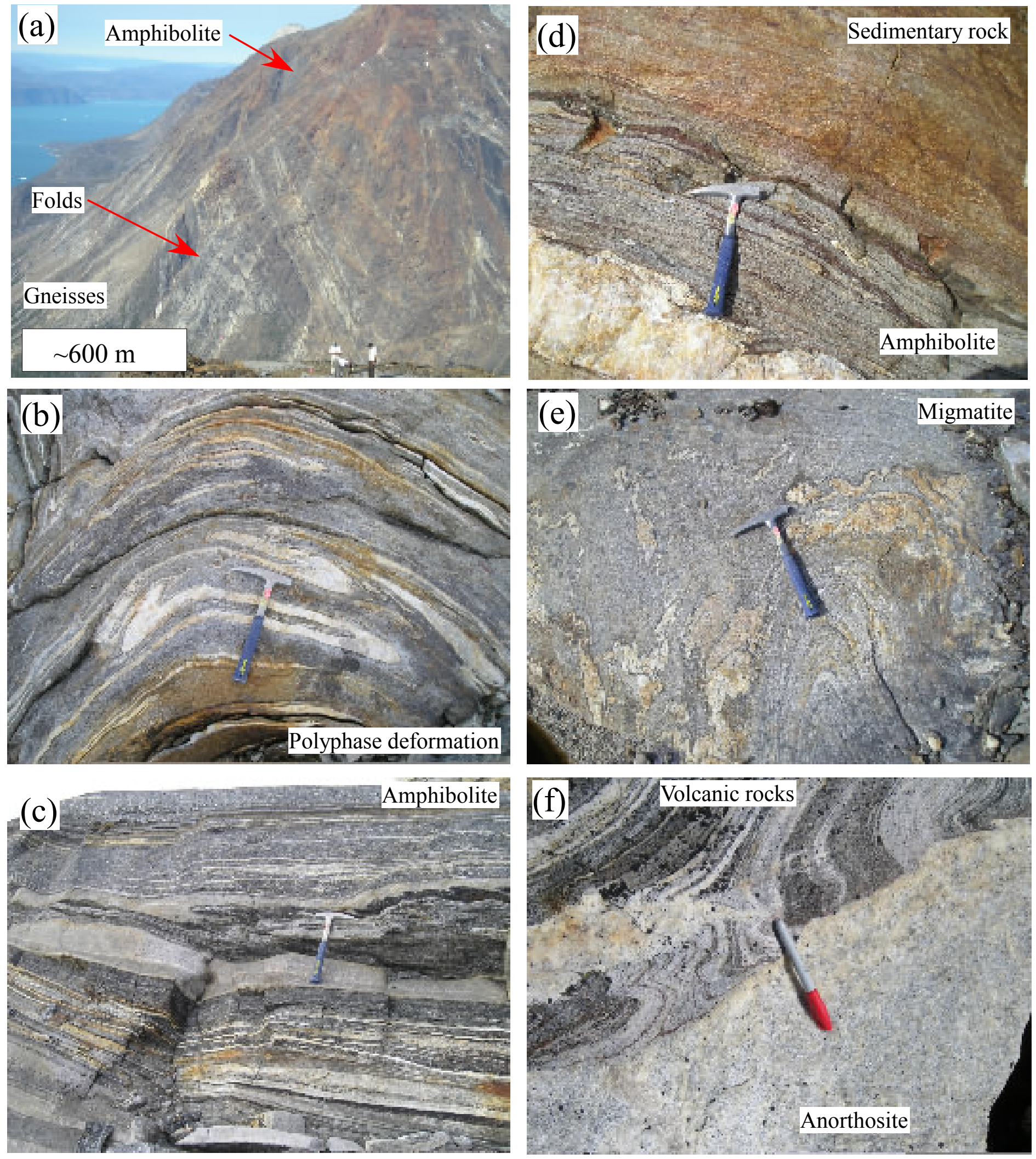

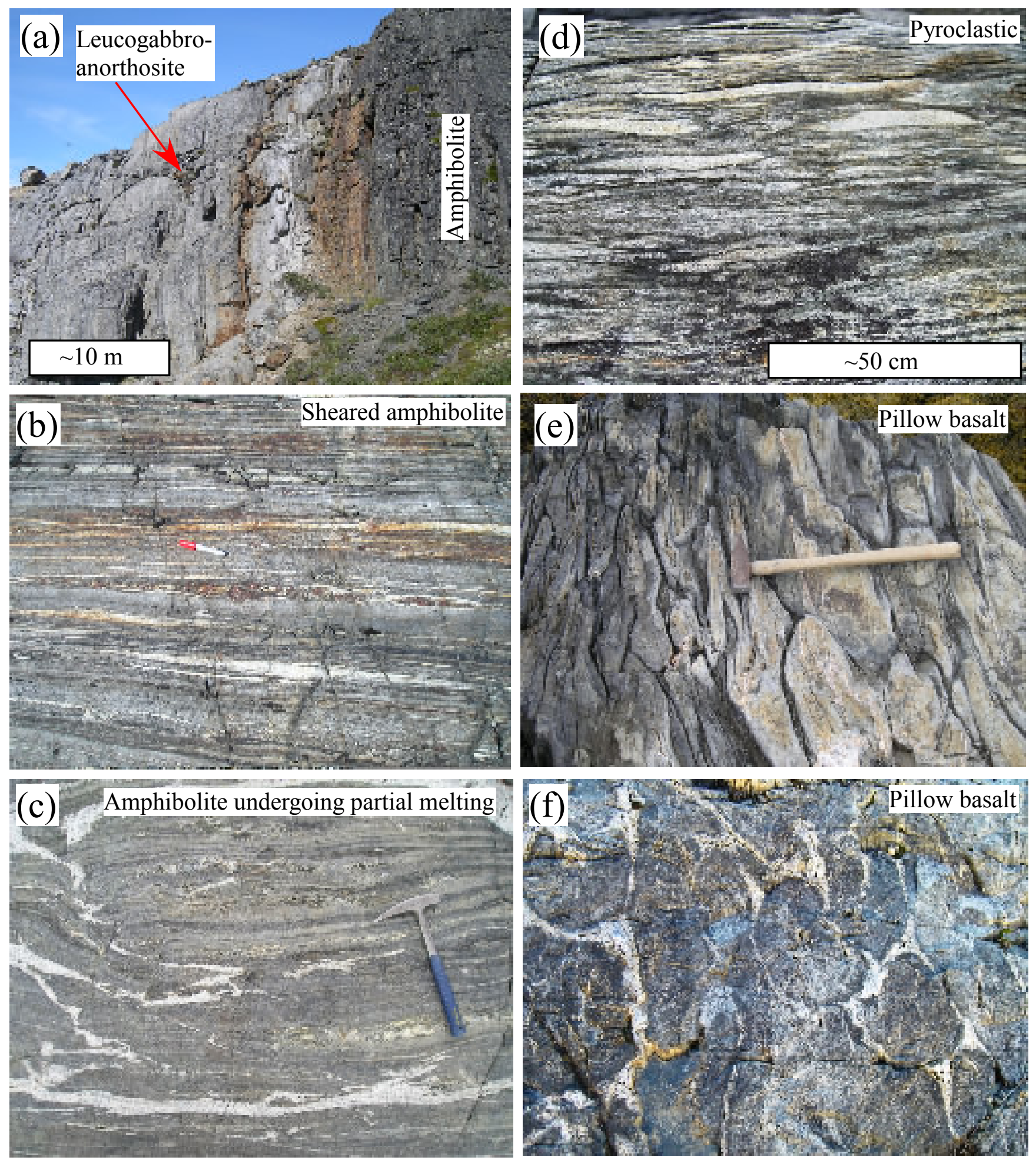


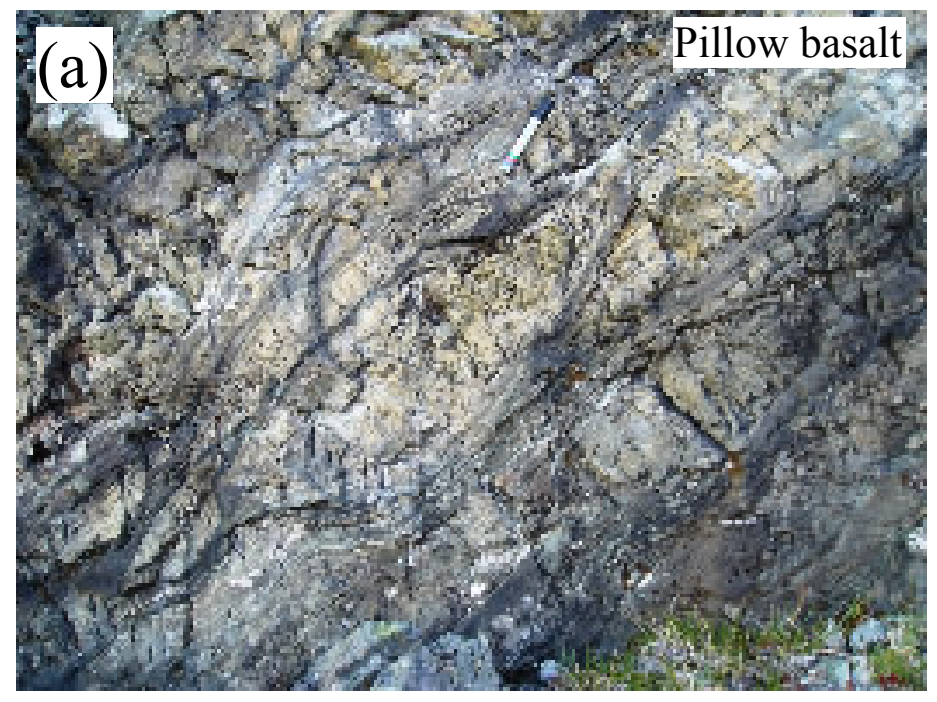

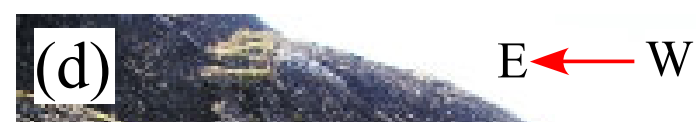
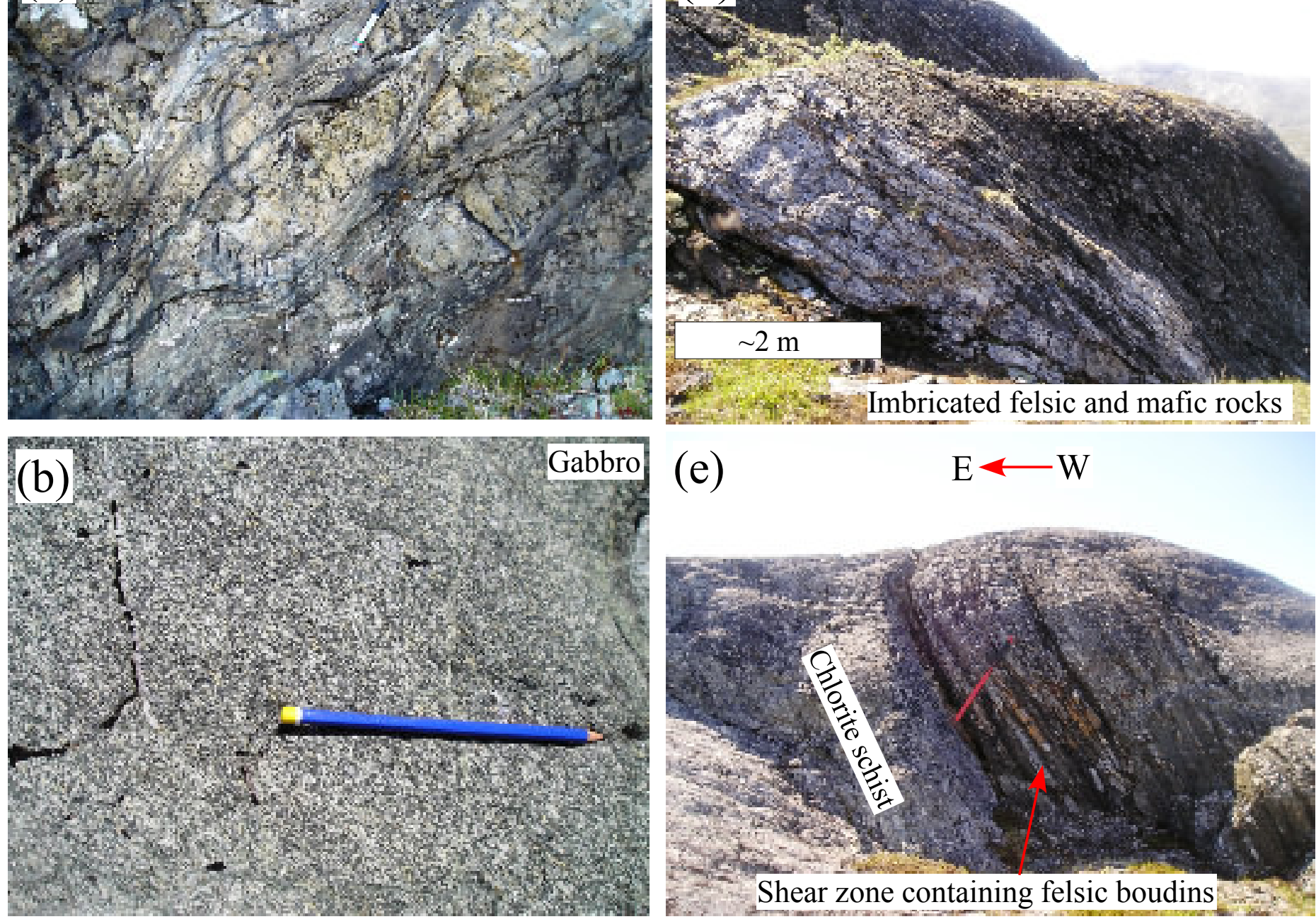

(e)

$\mathrm{E} \longleftarrow \mathrm{W}$
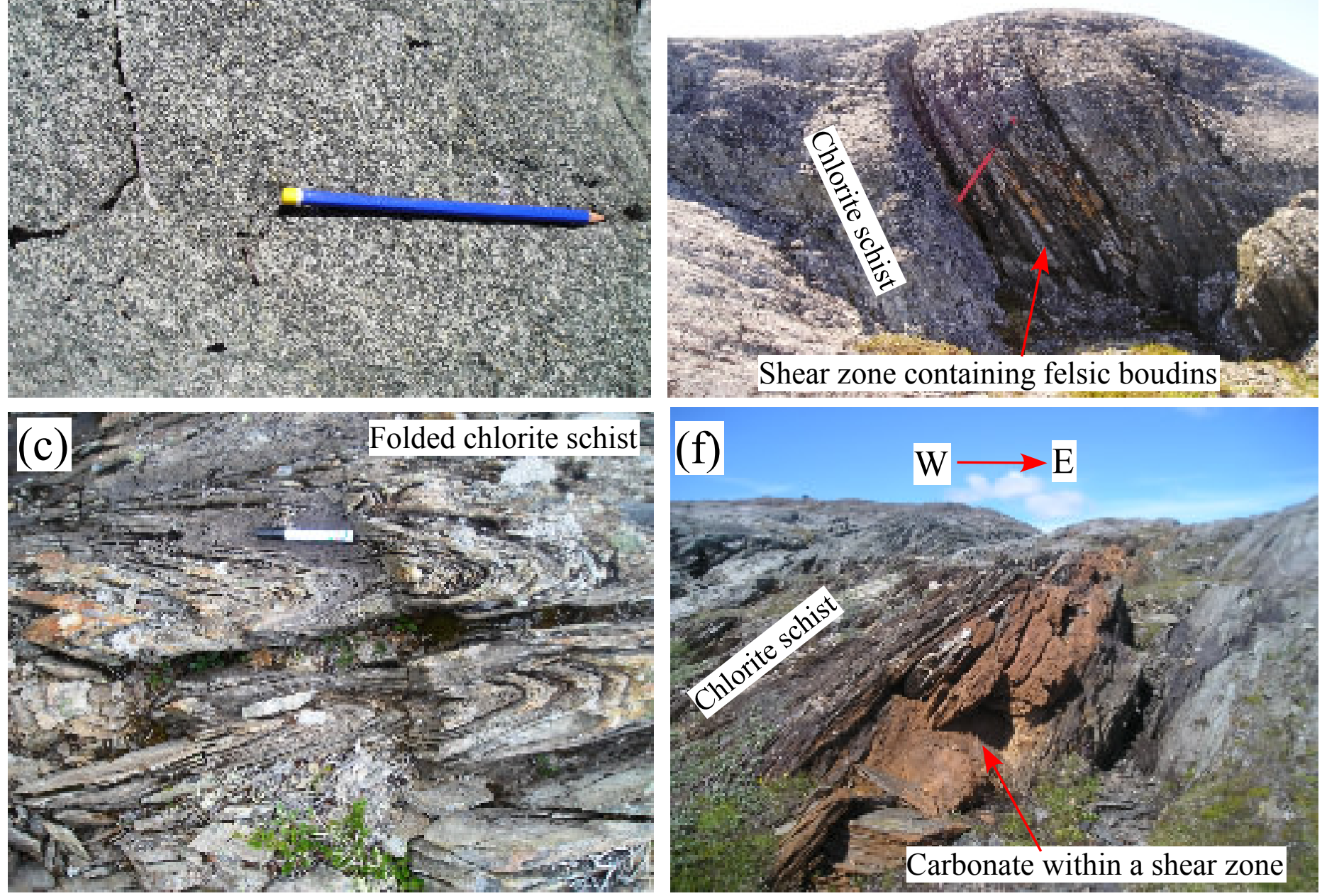
(a)

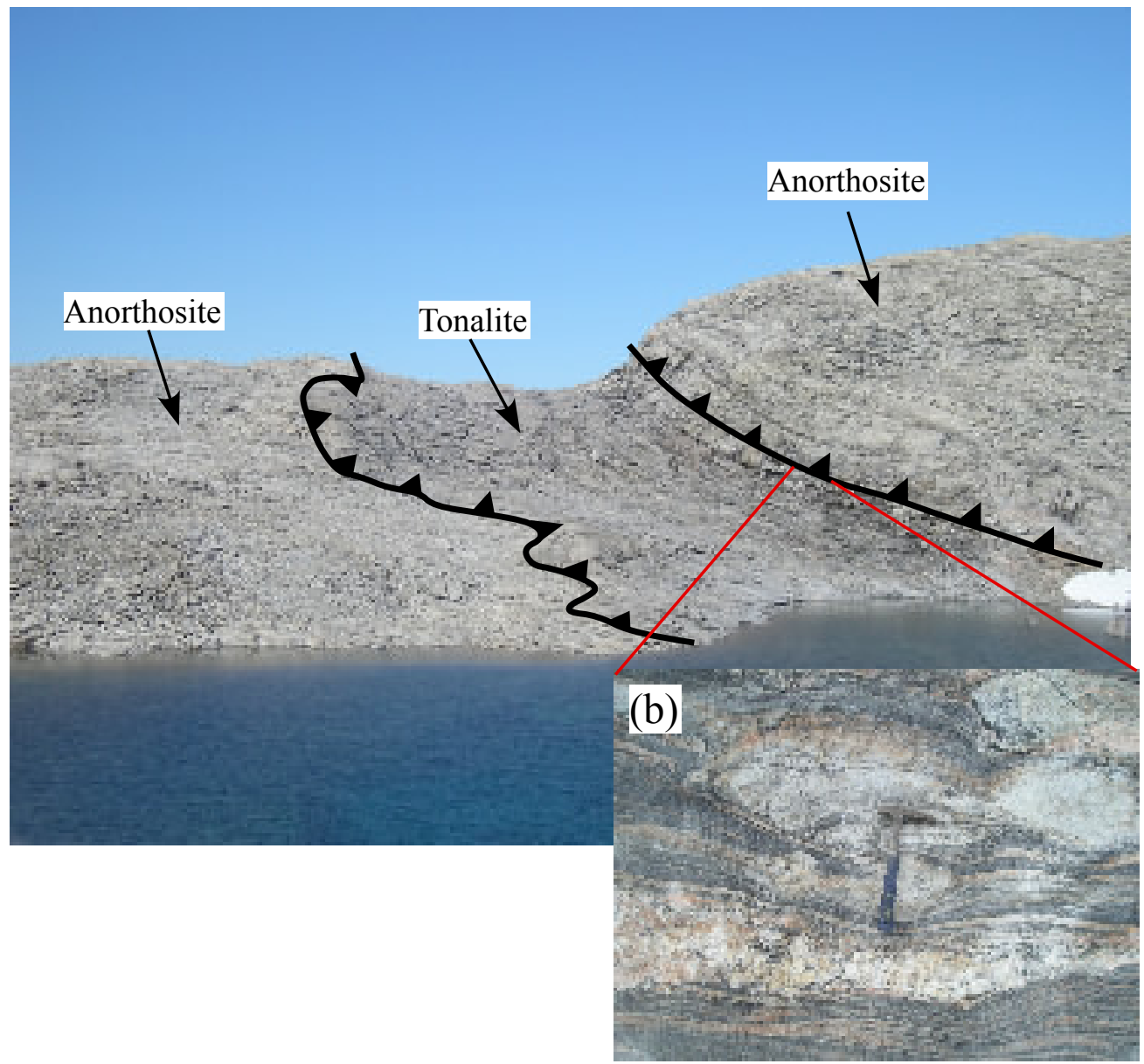

(c)

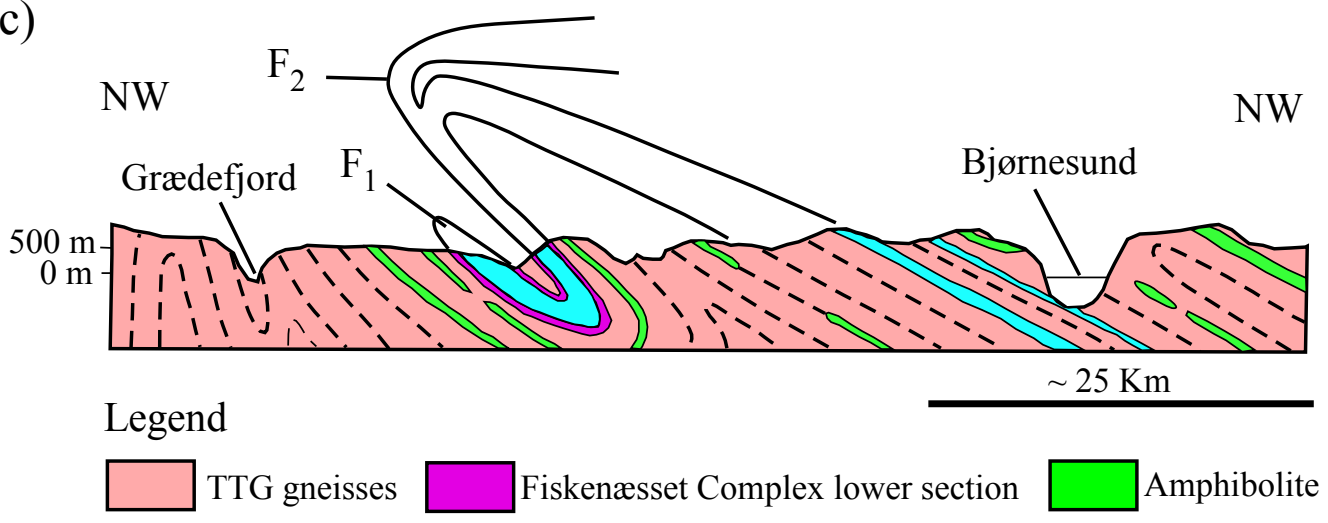

$\square$ Fiskenæsset Complex upper section $\quad----$ Foliation plane 

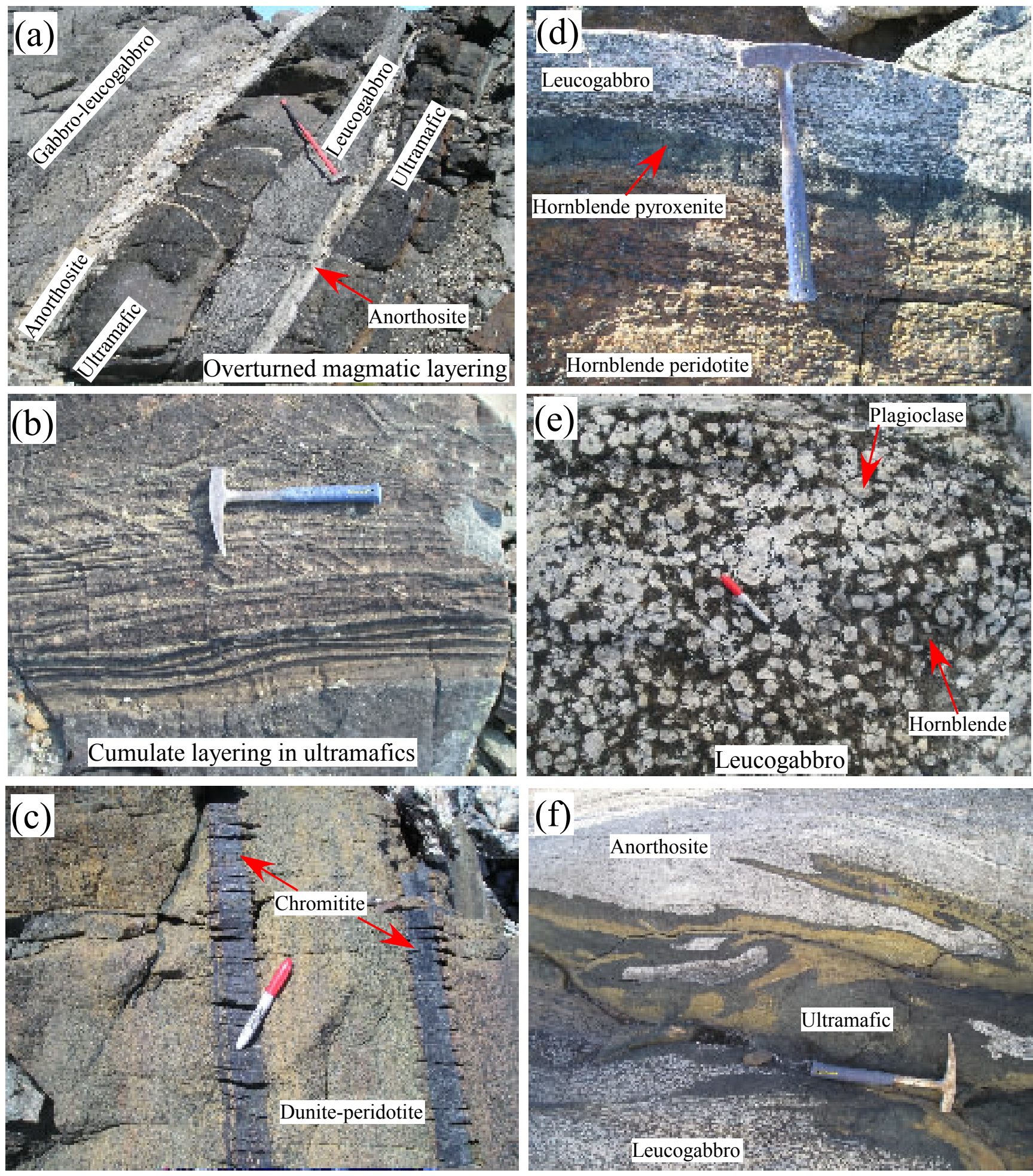

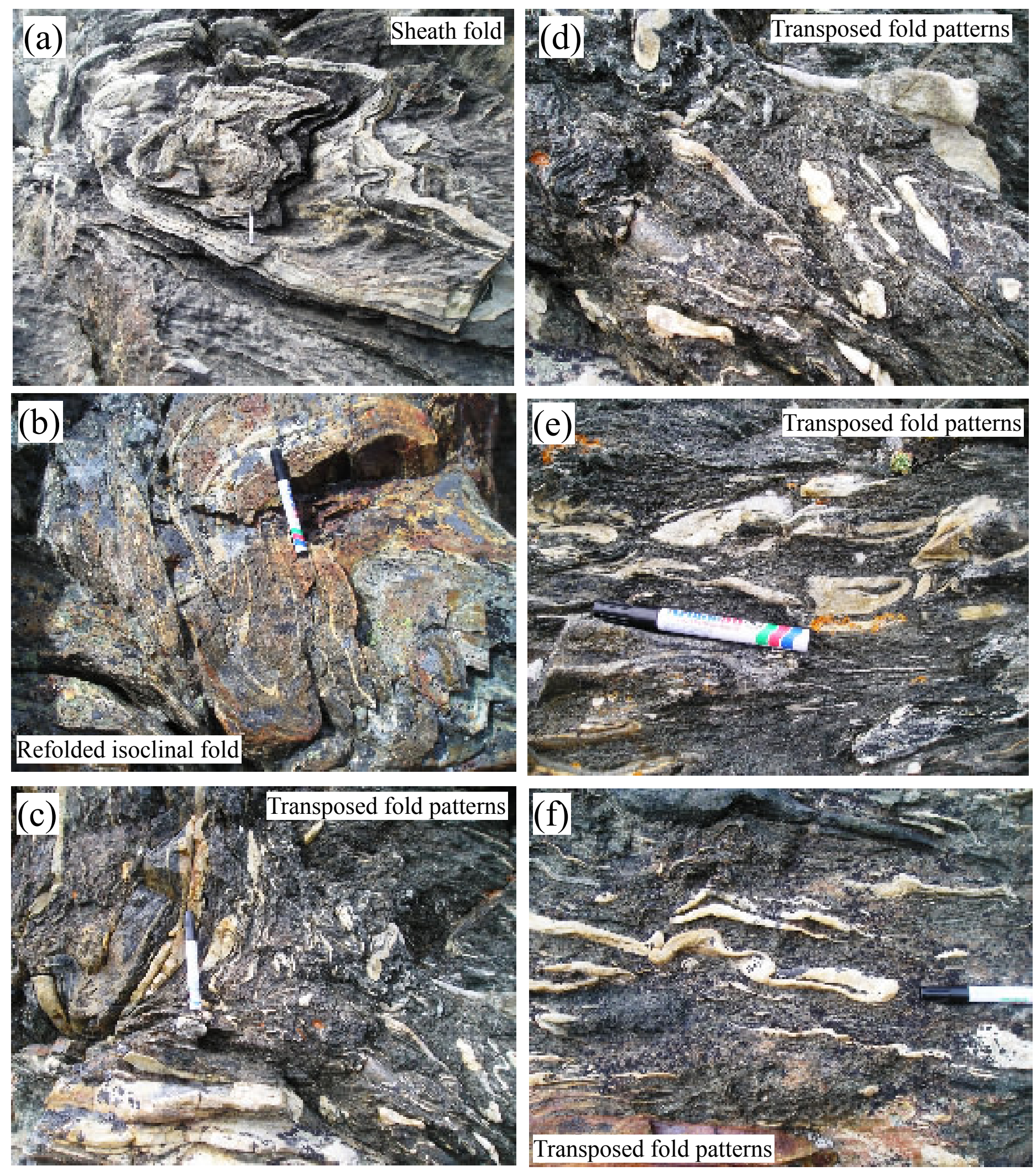

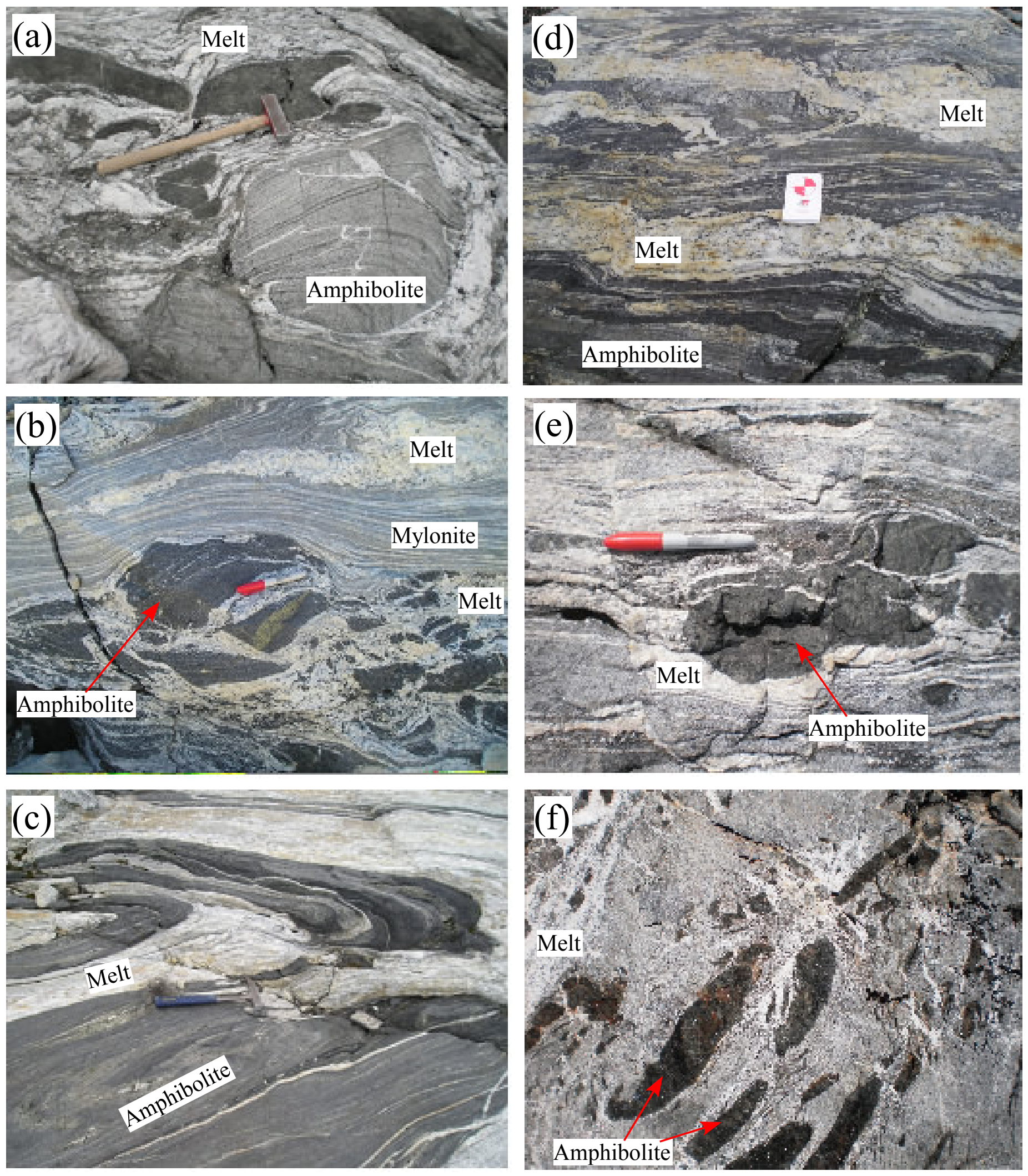

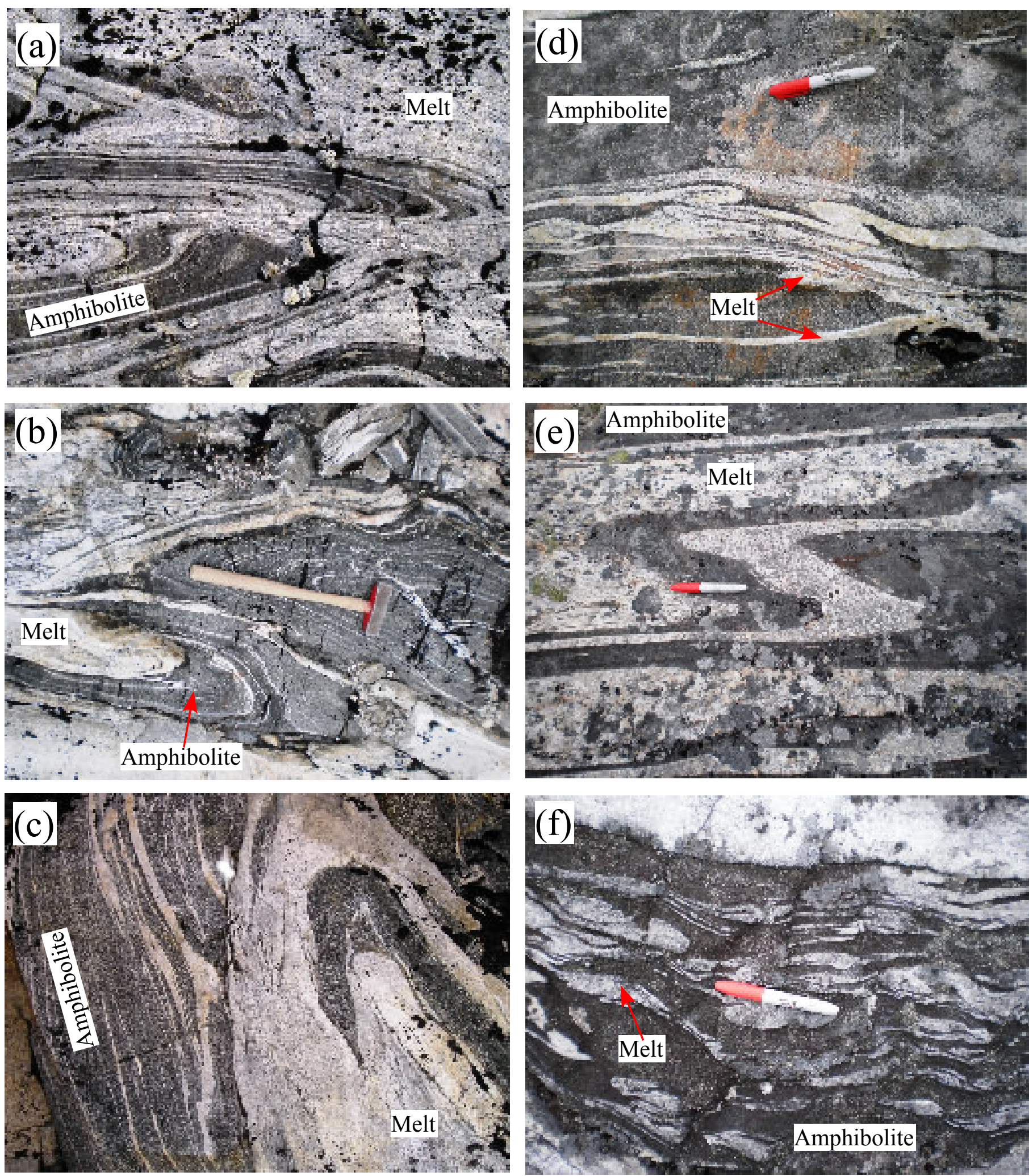
Arc

(volcanics and TTG)
Arc

(volcanics and TTG)
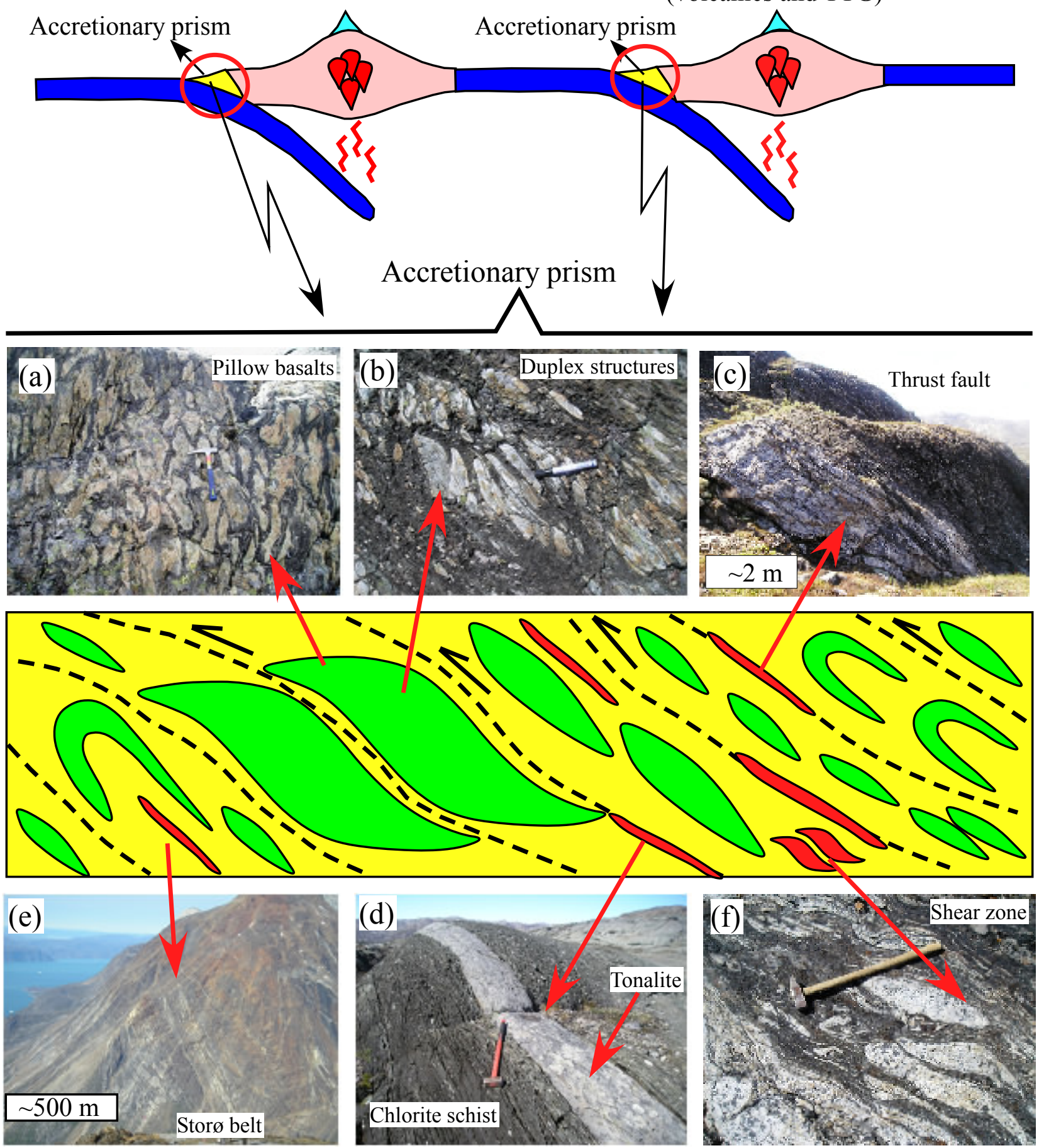

Legend

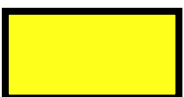

Sheared volcanic and sedimentary matrix

Felsic rocks (TTGs)

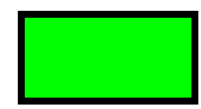

Fragments of accreted oceanic crust (basalts, gabbros, peridotites)

$$
-D_{-} \text {Major shear zone (thrust faults) }
$$




\section{New volcanic Archean Continental}
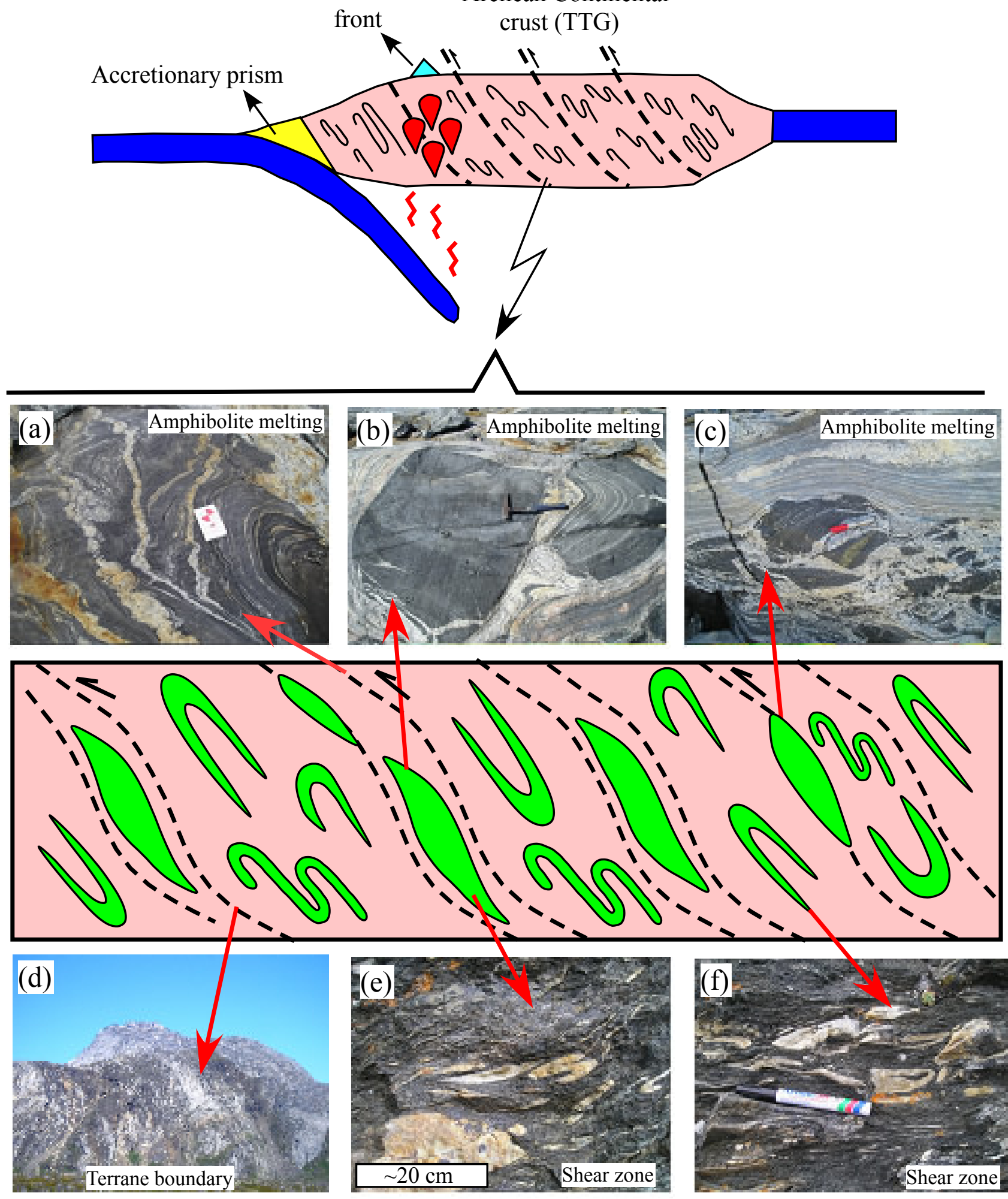


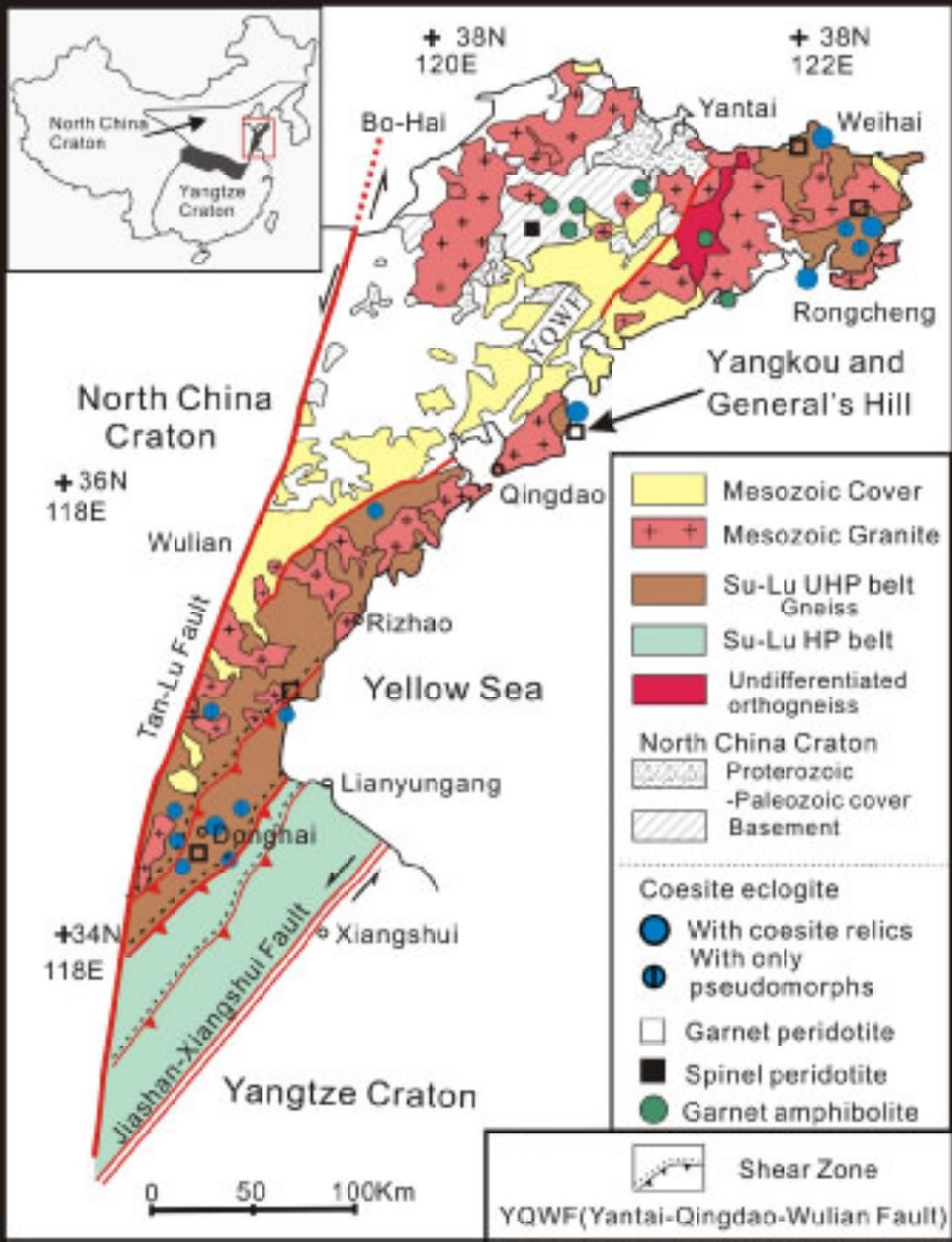


Mapping by T. Kusky, L. Wang, S.J. Wang, J.P. Wang and $Y$. Ding.

Original scale 1:2,000

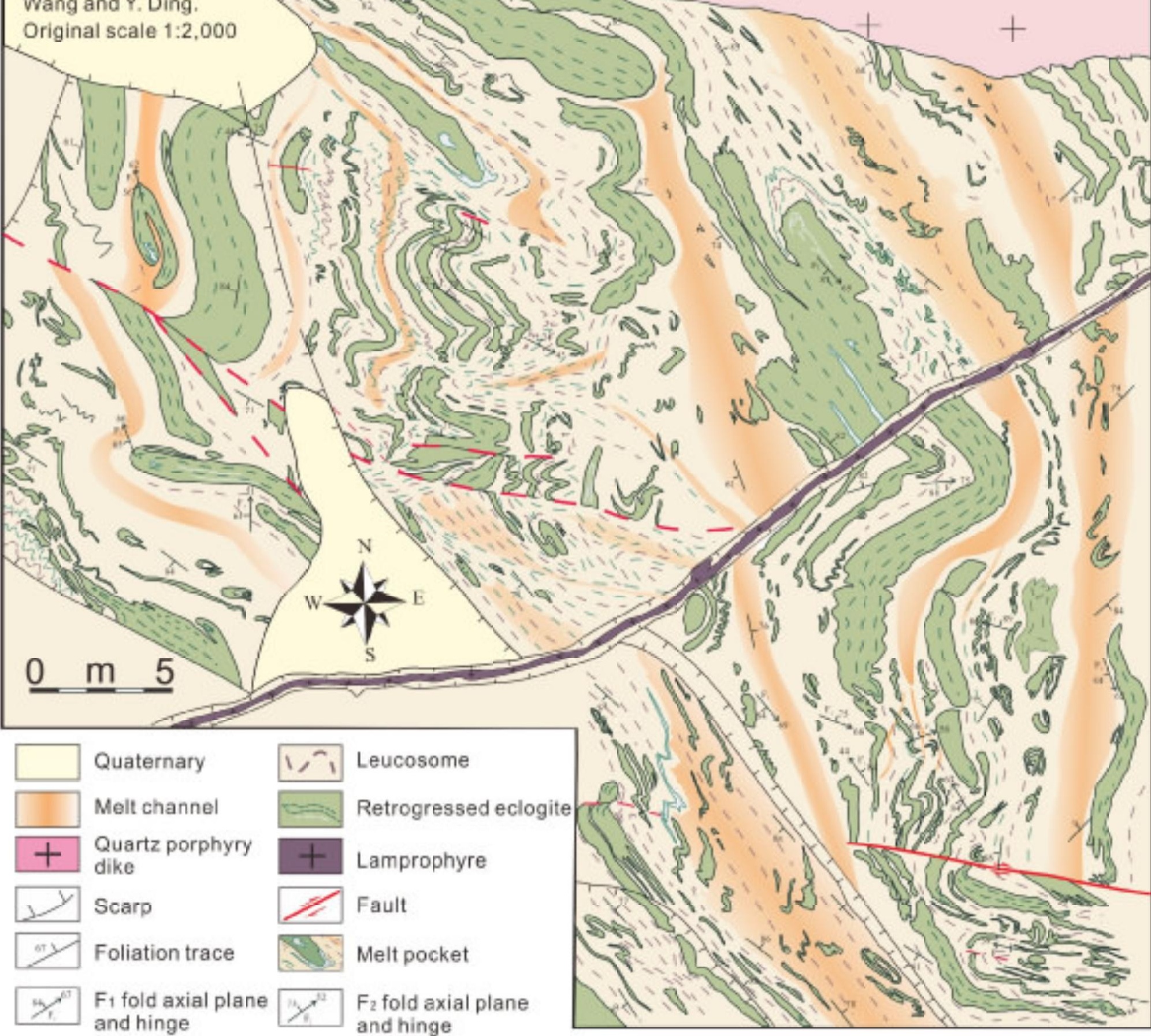



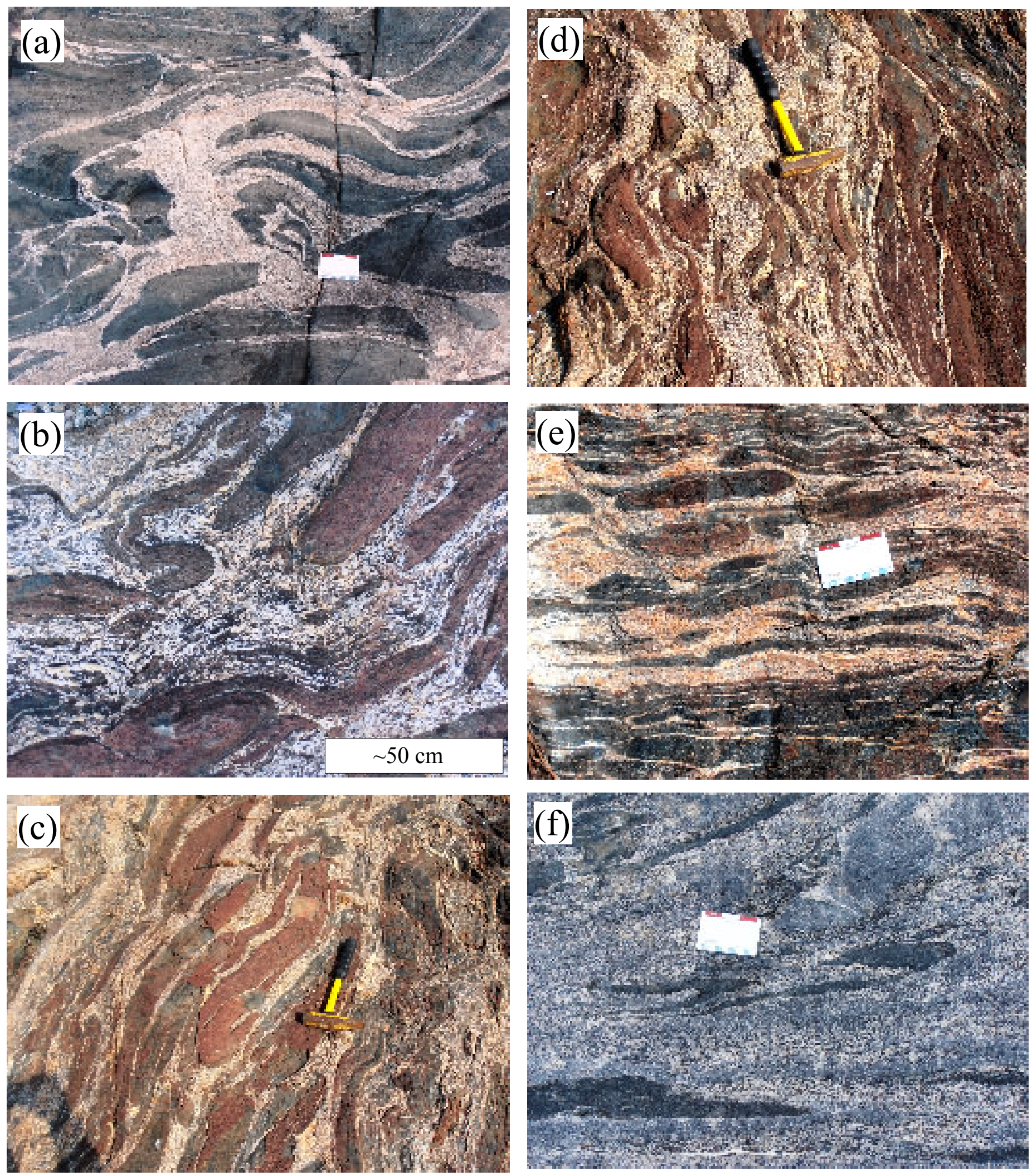
\begin{tabular}{ccc} 
Table 1. A list of representative layered intrusions, oceanic plateaus, ophiolites, and continental flood basalts; and their age (Ma) and thickness $(\mathrm{km})$. \\
\hline Layered intrusions & Oceanic plateaus & Ophiolites
\end{tabular}

Stillwater: $2700 \mathrm{Ma}$; ca. $6.5 \mathrm{~km}$

Bushveld Complex: 2060 Ma 8-9 km

Skaergaard: $55 \mathrm{Ma} ; 2.5 \mathrm{~km}$

Great Dyke: 2575 Ma; >2 km

Kiglapait: $1300 \mathrm{Ma} ; 8-9$ km

Rhum: $60 \mathrm{Ma} ; 1.5-2 \mathrm{~km}$
Ontong Java: 120-90 Ma; 15-32 km

Manihiki: 120-125 Ma; 35 km thick

Caribbean: 90-88 Ma; 20-22 km

Hikurangi: $120 \mathrm{Ma}$; $10-15 \mathrm{~km}$

Shatsky Rise: 147 Ma; $10-28$ km

South Kerguelen: 110 Ma; 22 km

Central Kerguelen: $86 \mathrm{Ma} ; 19-21 \mathrm{~km}$
Oman (Semail): 96-90 Ma; $12-14 \mathrm{~km}$

Troodos (Cyprus): 92-90 Ma; 6-6.5 km

Bay of Islands: 500-485 Ma; 8-9 km

Papua New Guinea: 71-65 Ma; 12-14 km

Zambales-Coto: $45 \mathrm{Ma} ; 10 \mathrm{~km}$

Duke Island: 108-111 Ma; 3 km
Continental flood basalts

Keweenawan: 1100-1070 Ma; 8 to $15 \mathrm{~km}$

Siberian traps: $250 \mathrm{Ma} ; 3.5 \mathrm{~km}$

Karoo traps: $180 \mathrm{Ma} ; 1.5 \mathrm{~km}$

Parana traps: 120-140 Ma; 1.5 km

Deccan traps: 65-66 Ma; 1.5 km 